\title{
ASPEK-ASPEK FISIK DALAM PENGELOLAAN KAWASAN KARST: SEBUAH USULAN
}

\author{
Ahmad Cahyadi \\ Kelompok Studi Karst \\ Departemen Geografi Lingkungan \\ Fakultas Geografi Universitas Gadjah Mada
}

\section{Sabtu, 25 November 2017}

Diselenggarakan oleh:

Biospeleology Studien Gruppen

Himpunan Mahasiswa Jurusan Pendidikan Biologi

Fakultas Matematika dan IImu Pengetahuan Alam

Universitas Negeri Yogyakarta

2017 


\section{Menelisik Arti “Karst”}

\subsection{Latar Belakang}

* Perkembangan keilmuan karstologi dan speleology di sekitar 30-40 tahun terkahir terbilang sangat pesat;

* Banyak teori dan definisi yang berubah dengan diketemukannya hasil-hasil penelitian terbaru

- Definisi terkait karst-pun turut berubah, termasuk persayaratan morfologi yang selalu digunakan sebagai syarat utama penyebutan bentanglahan karst

* Penelitian mendalam tentang "hypogene cave" telah mengubah banyak sudut pandang yang digunakan untuk memelajari kawasan karst terutama terkait dengan aspek fisik 


\section{Menelisik Arti “Karst”}

\subsection{Definisi Karst}

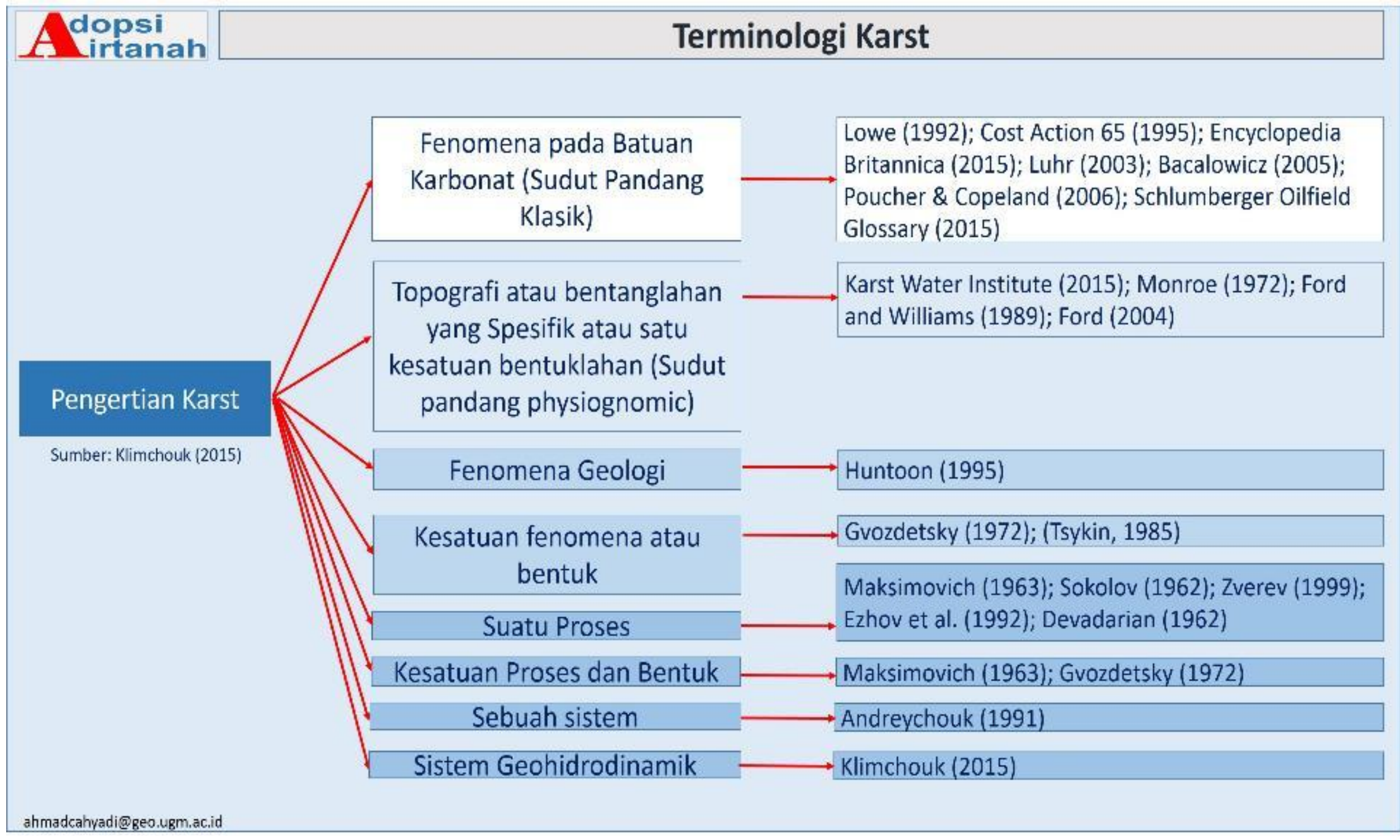




\section{Menelisik Arti “Karst”}

1.2. Karst sebagai wilayah dengan batuan gamping atau dolomit?

* Pada kenyataanya karst dapat berkembang pada batuan yang lain, meskipun singkapan selain gamping dan dolomit lebih sedikit di dunia;

* Pada kenyataanya wilayah dengan batuan gamping dan dolomit tidak memiliki karakteristik kawasan karst, sehingga secara hidrologi masih didominasi oleh aliran airtanah pada ruang antar butir batuan;

- Pada kenyataannya wilayah dengan batuan gamping dan dolomit membentuk kondisi wilayah yang berbeda-beda 


\section{Menelisik Arti “Karst”}

1.3. Kawasan Karst Indonesia sudah terpetakan?

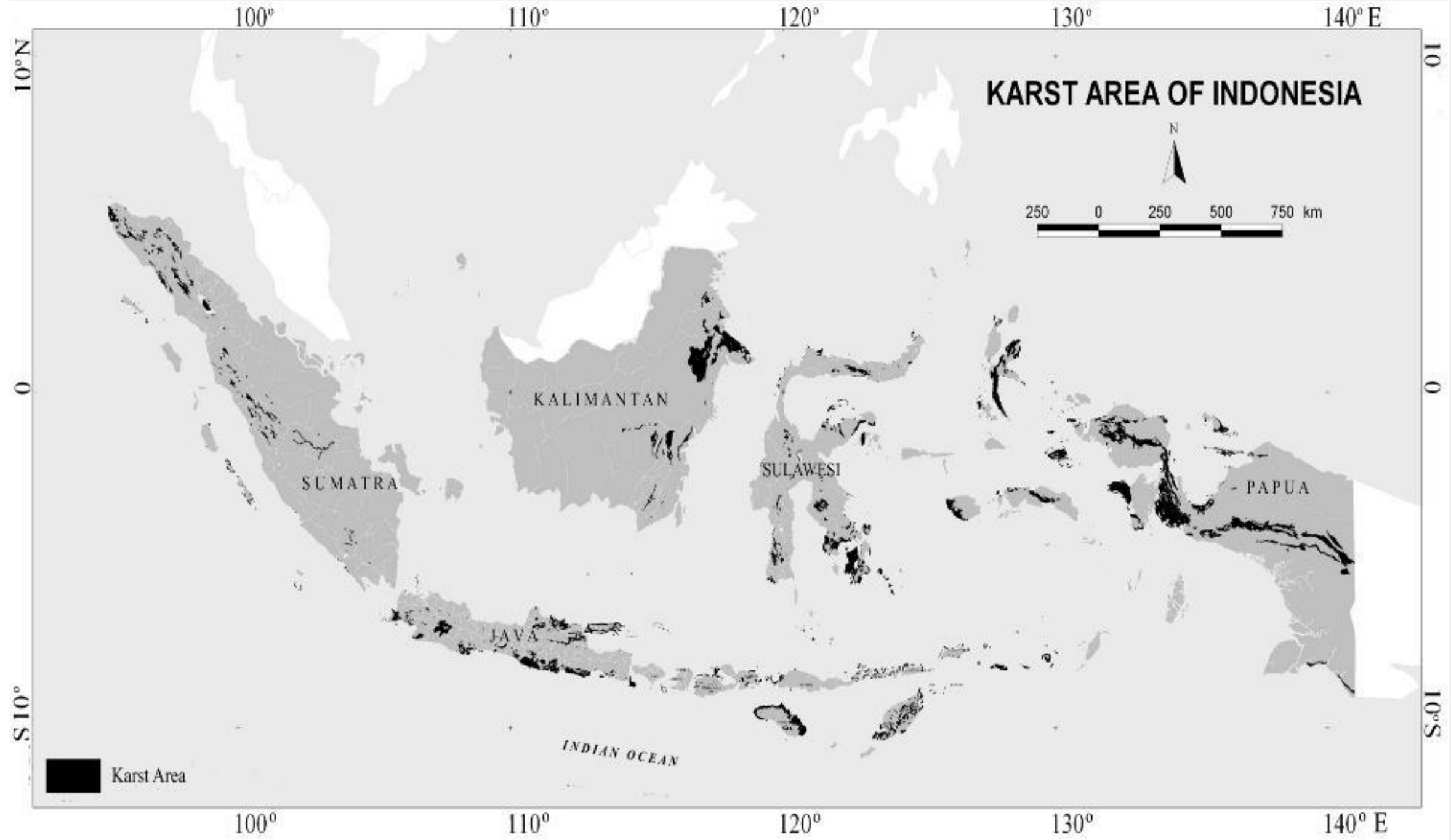




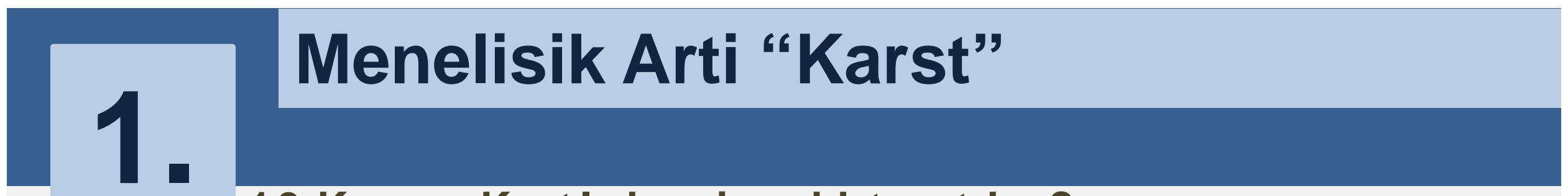

1.3. Kawasan Karst Indonesia sudah terpetakan?

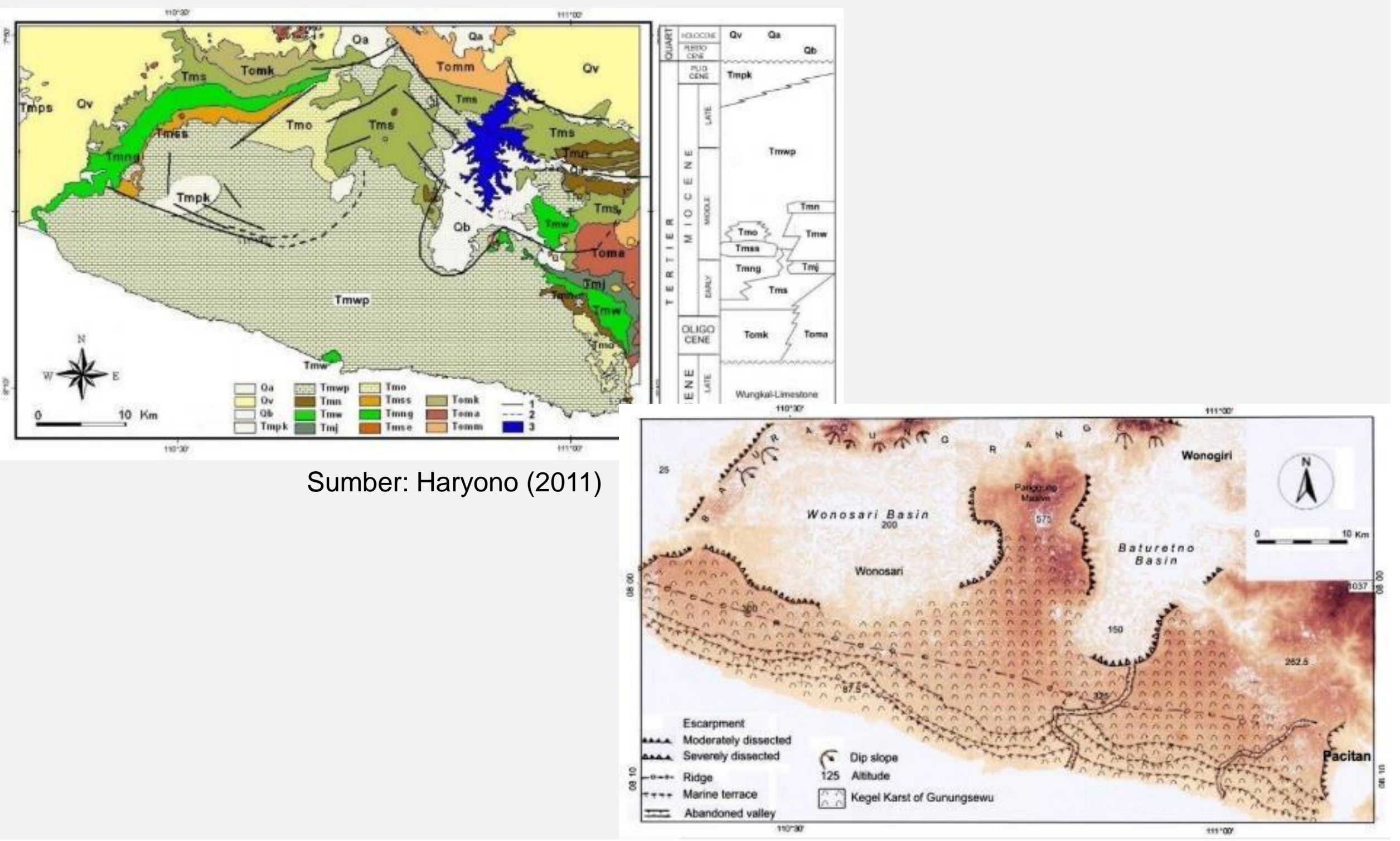




\section{Menelisik Arti “Karst”}

\subsection{Pembentukkan Kawasan Karst}

\begin{tabular}{|c|c|}
\hline \multicolumn{2}{|c|}{ Bentanglahan Karst dan Pseudokarst Serta Proses yang Membentuknya } \\
\hline Tipe Batuan & Proses yang Membentuk \\
\hline \multicolumn{2}{|l|}{ KAWASAN KARST } \\
\hline Batuan Karbonat misalnya gamping dan dolomit & Pelarutan Bikarbonat \\
\hline Batuan Evaporit misalnya gypsum, halite dan anhydrite & Pelarutan \\
\hline \multicolumn{2}{|l|}{ KAWASAN PSEUDOKARST } \\
\hline Basalt & $\begin{array}{l}\text { Perpindahan batuan cair serta pada beberapa tempat } \\
\text { teriadi pelarutan kalsium plagioklas }\end{array}$ \\
\hline $\begin{array}{l}\text { Tanah khususnya yang memiliki "duplex profiles". Duplex profiles adalah profil tanah } \\
\text { dengan karakteristik tekstur yang sangat kontras antara dua atau lebih horizon tanah. } \\
\text { Istilah lain yang sering digunakan adalah "texture contrast soils". }\end{array}$ & Hilangnya salah satu horizon pada tanah \\
\hline Batuan karakteristik berlapis dan atau berfolisasi & Pemetikan Hidraulik (hydraulic plucking and exsudation) \\
\hline Batuan (hampir semua ienis batuan) & Gerakan/Gaya Tektonik. \\
\hline Batu Pasir, kuarsa, kuarsit dan batuan lain dengan litologi granular & Disintegrasi butir batuan dan erosi oleh angin \\
\hline ES & Perpindahan masa akibat mencairnya sebagian massanya \\
\hline Batuan dengan kandungan silikat tinggi misalnya batu pasir, basalt, granit dan laterit & Pelarutan Silika \\
\hline $\begin{array}{l}\text { Formasi Besi (di Brazil terdapat suatu wilayah yang tersusun atas batuan dengan } \\
\text { kandungan besi yang tinggi, atau disebut sebagai "iron formation" }\end{array}$ & Pelarutan \\
\hline
\end{tabular}




\section{Menelisik Arti "Karst"}

1.

1.5.

Tingkat

Perkembangan Kawasan Karst

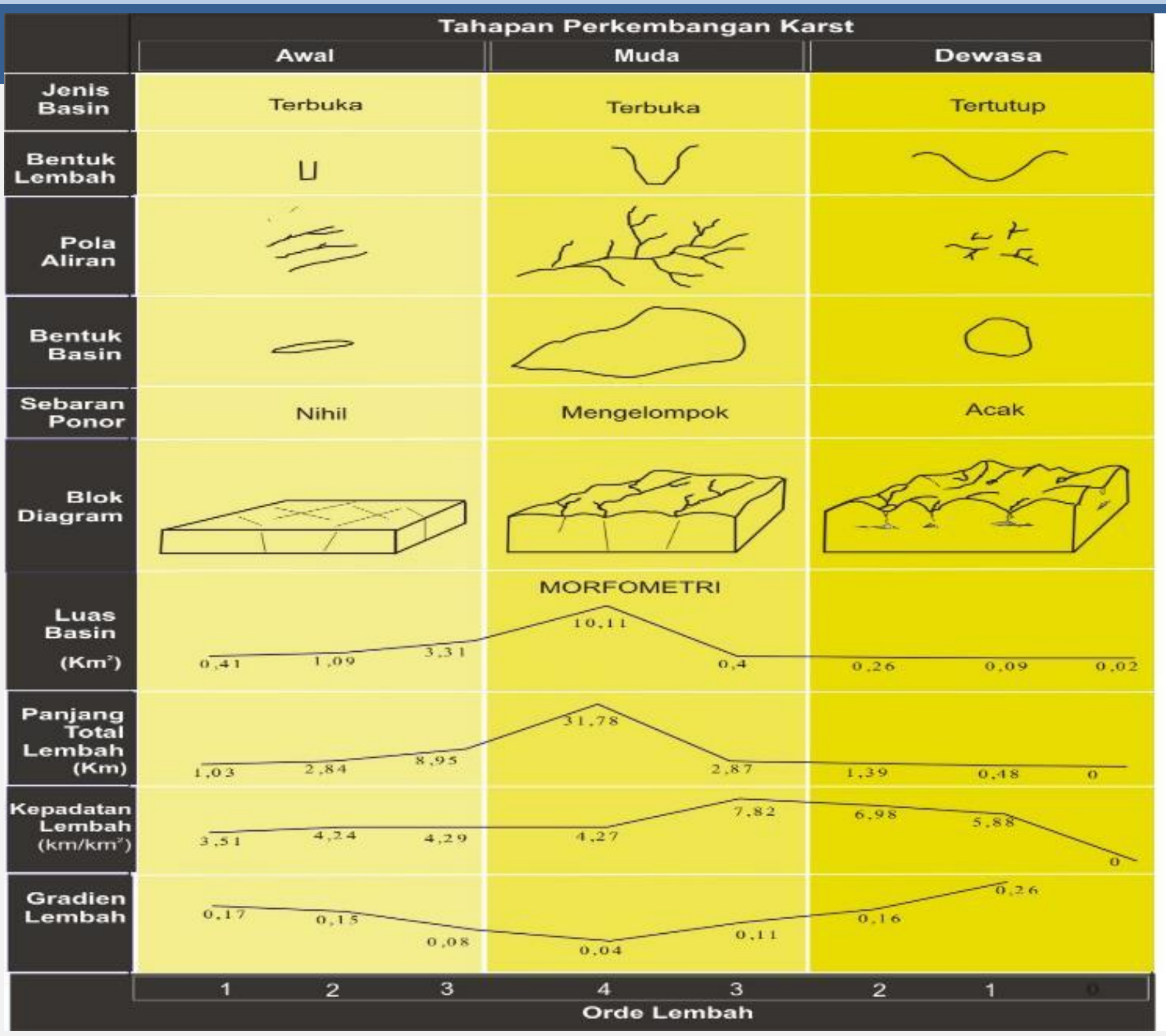

Sumber: Haryono (2009) 


\section{Menelisik Arti “Karst”}

1.5.

\section{Tingkat}

\section{Perkembangan} Kawasan Karst

\section{Tingkat Karstifikasi}

$0.5-2.3$

$Q_{t}=Q_{01} e^{-\alpha i t}$

$2.5-4.0 \quad Q_{t}=Q_{01} e^{- \text {att }}+Q_{02} e^{-\operatorname{Eat} t}$

$4.3-5.0 \quad Q_{t}=Q_{01} e^{* \pi i t}+Q_{04}\left(1 \cdot \beta_{1} t\right)$

$5.5 \quad Q_{t}=Q_{01} e^{-.41 t}+Q_{02} e^{-0.2 t}+Q_{04}\left(1-Q_{1} l\right)$

$6.0 \quad Q_{t}=Q_{01} e^{-\pi 1 t}+Q_{02} e^{-02 t}+Q_{04}\left(1-\beta_{1} t\right)+Q_{03}\left(1-\beta_{2} t\right)$

$7.0 \quad Q_{t}=Q_{01} e^{-\alpha i t}+Q_{04}\left(1-\beta_{1} t\right)+Q_{03}\left(1-\beta_{2} t\right)+Q_{06}\left(1-\beta_{8} t\right)$

$8.5 \quad Q_{t}=Q_{04}\left(1-\beta_{1} t\right)$

$9 \quad Q_{t}=Q_{04}\left(1-\beta_{1} t\right)+Q_{03}\left(1-\beta_{2} t\right)$

$10.0 \quad Q_{t}=Q_{04}\left(1-\beta_{1} t\right)+Q_{05}\left(1-\beta_{2} t\right)+Q_{06}\left(1-\beta_{3} t\right)$
Parameter Koefisien resesi

$\alpha_{1}<0.001$

$\alpha_{1}=0.001-0.0025$

$\alpha_{1}=0.0025-0.007$

$\alpha_{1}>0.007$

$\alpha_{1}<0.0024$ dan $\alpha_{2}<0.033$

$\alpha_{1}>0.0043$; dan $\alpha_{2}<0.060$

$\alpha_{1}>0.018$ atau $\alpha_{2}>0.16$

$\alpha_{1}>0.018$ dan $\alpha_{2}>0.16$

Nilai $\beta$ dan $\alpha$ rendah

$\alpha_{1}>0$ dan $\alpha_{2}>0 ; \beta_{1}>0$

Nilai $\beta_{2}, \beta_{1}$ dan $\alpha_{1}, \alpha_{2}$ tinggi

Nilai $\beta_{3}, \beta_{2}, \beta_{1}$ dan $\alpha$ tinggi, $\beta_{1}>\beta_{2}$

$\alpha_{1}, \alpha_{2}=0$ dan $\beta_{1}>0$

Nilai $\beta_{1}$ dan $\beta_{2}$ rendah

Nilai $\beta_{1}, \beta_{2}$, dan $\beta_{3}$ tinggi

Sumber : Malik and Votjkova (2012) 


\section{Menelisik Arti “Karst”}

\subsection{Diagenesis dan Regime Aliran Airtanah}

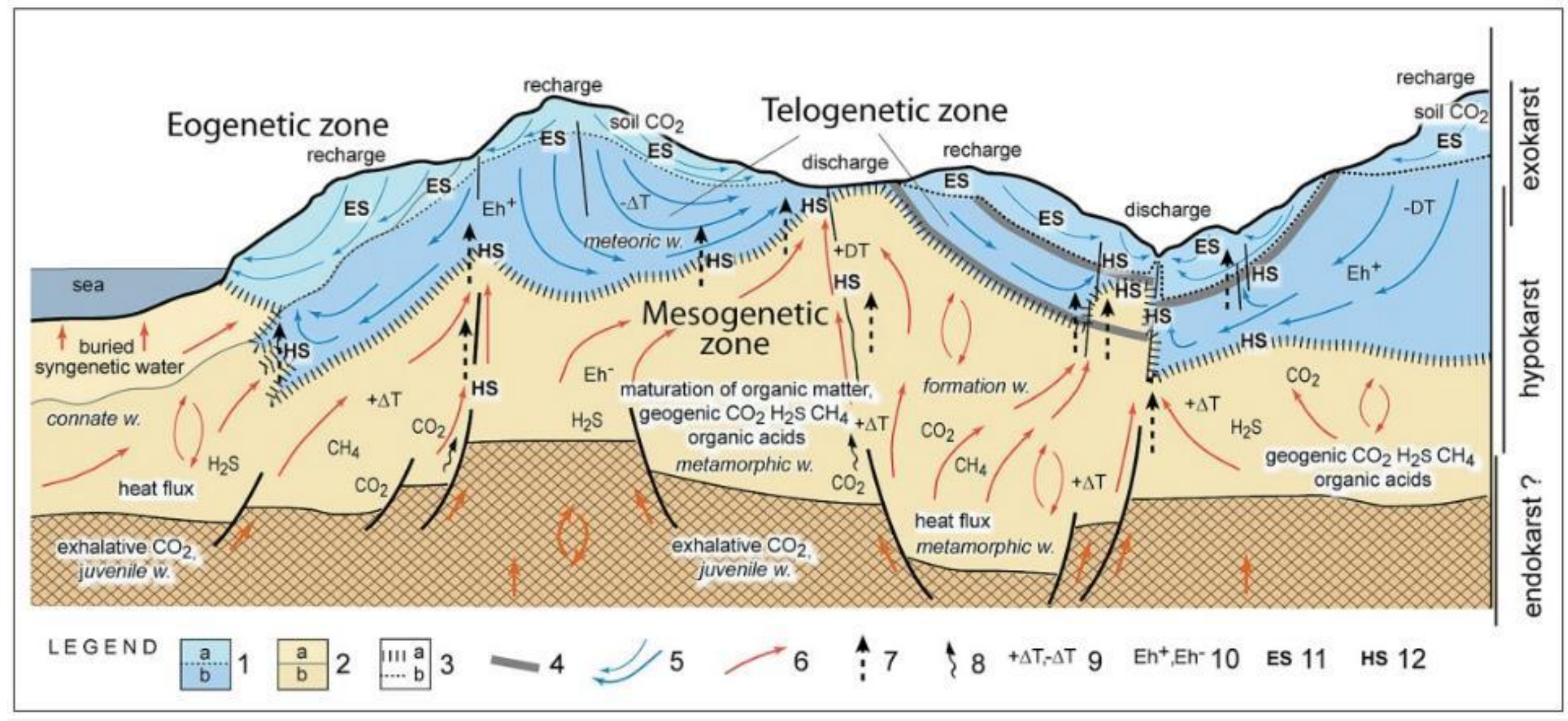

Sumber: Klimchouk (2015) 


\section{Menelisik Arti “Karst”}

\subsection{Zonasi Vertikal Kawasan Karst}

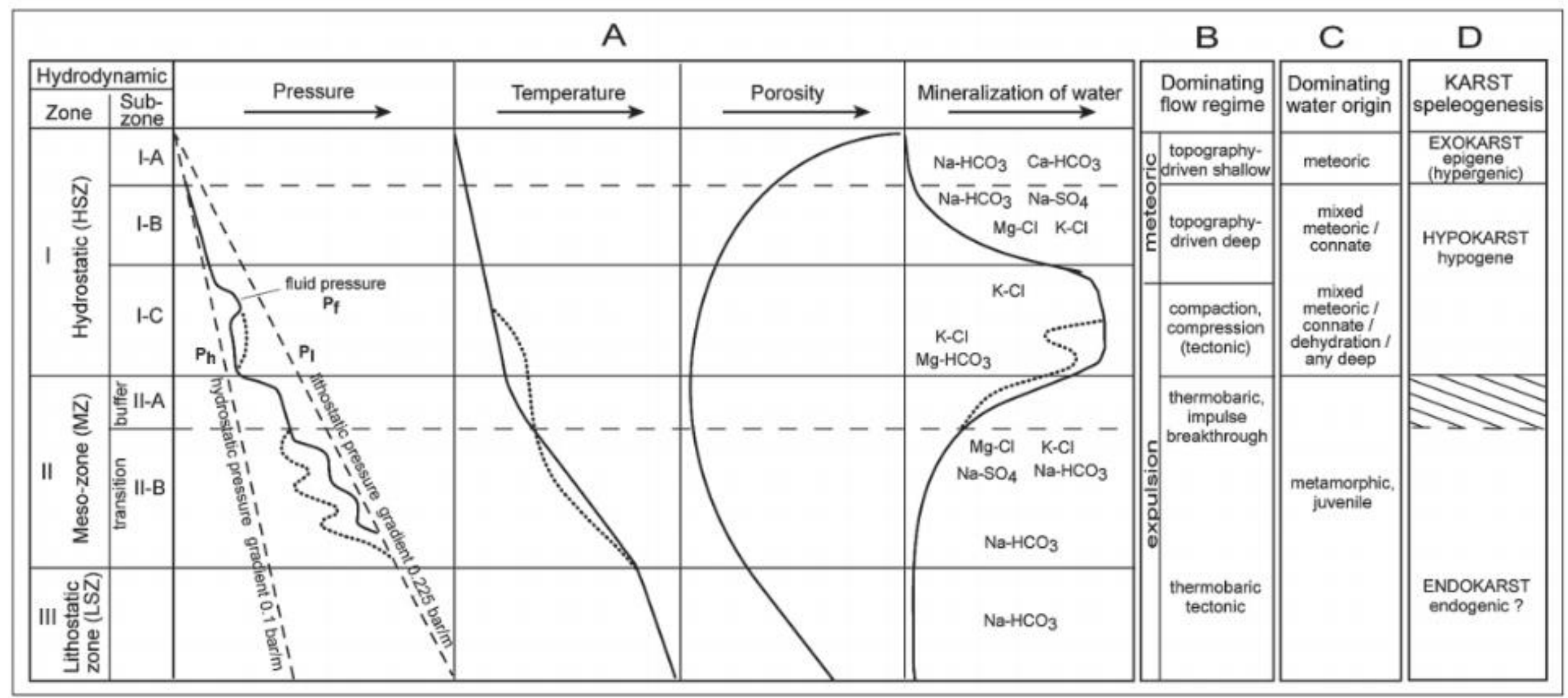

Sumber: Klimchouk (2015) 


\section{Menelisik Arti “Karbonat”}

\section{Definition and Classification of Limestone}

Prepared by Missouri Department of Natural Resources, Division of Geology and Land Survey, 2011

Academic, Geological Definition of Limestone (stipple pattern)

\section{Sources for Nomenclature}

American Society for Testing and Materials, 1966, ASTM C119-50 in Book of Standards, for definition of calcite limestone (pp.103-105)

Neendorf, K.K.E., Mehl, James P., Jr., and Jackson, Julia, 2005, Glossary of geology, 5th

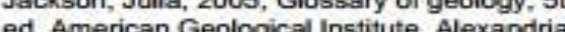
ed. Amenican Geological instite, Alexandria, Virginia, 770p., for geological and commercia definitions of definitions of dolomitic limestone (p.189), calcitic dolomite (p.92), dolomite (p.189) and magnesian dolomite (p.388)

Pettijohn, F.J., 1957, Sedimentary rocks, 2nd ed., Harper, New York, $718 \mathrm{p}$., for definitions of high-calcium limestone, magnesian limestone. dolomitic limestone, calcitic dolomite and dolomite (p.417-18)

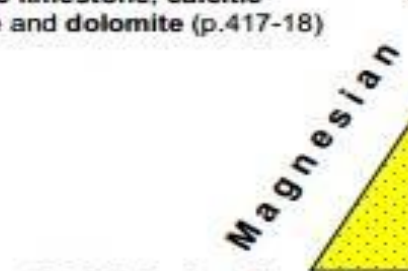

$100 \%$ Dolomite $\mathrm{CaMg}\left(\mathrm{CO}_{3}\right)_{2}$

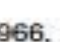

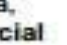
ial

\author{
9)
} $50 \%$

\author{
10
}
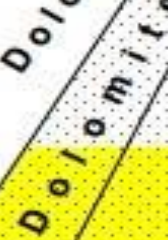

$\%$

$100 \%$ Other

Rock Materials

(Chert, Ouartz Sand \& Silt, Clay, etc.)

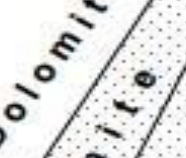

$50 \%$

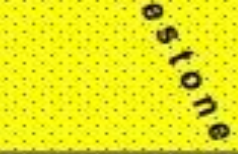

Magnesian

Limestone

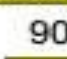

$9 0 \% \longdiv { 9 5 \% }$

Practical, Commercial Definition

of Limestone (yellow color)

Sources for Nomenclature (continued) Society of Mining Engineers, 1446p., for triangle

classification diagram (p.836) that has been adopted with modification for use herein.

Thrush, Paul W. and Staff of Bureau of Mines, 1968, A dictionary of mining, mineral, and related terms, U.S. Bureau of Mines, 1269p., for broad definition of limestone (p.643) and for

definitions of calcite limestone and calcitic dolomite (p.163)

Tweney, C.F., and Hughes, L.E.C., 1958 , Chamber's technical dictionary. 3rd ed., broad definition of lim, (s) (supplement, pp.952-1028)

\section{$80 \%$}

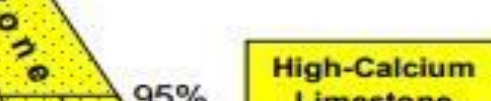

$100 \%$ Calcite 


\section{Menelisik Arti “Karbonat”}

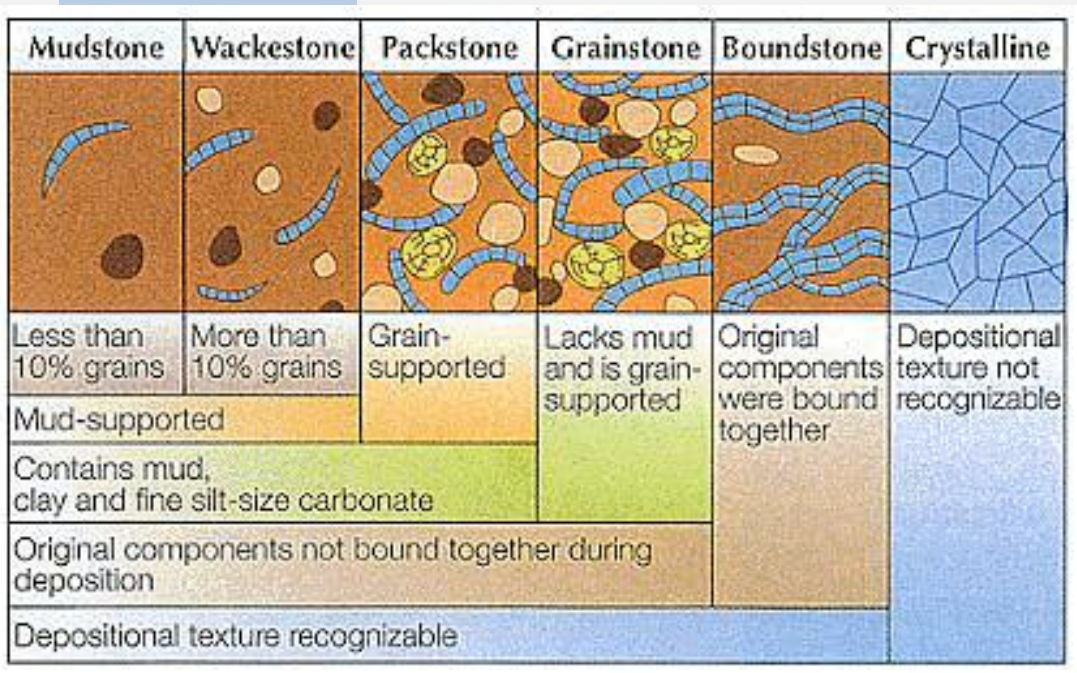

Folk's Textural Classification of Carbonate Sediments

\begin{tabular}{|c|c|c|c|c|c|c|c|c|}
\hline \multirow[b]{2}{*}{$\begin{array}{c}\text { Percent } \\
\text { Allochems }\end{array}$} & \multicolumn{4}{|c|}{ Over 2/3 Micrite Matrix } & \multirow{2}{*}{$\begin{array}{l}\text { Subequal } \\
\text { Spar \& } \\
\text { Micrite }\end{array}$} & \multicolumn{3}{|c|}{ Over 2/3 Spar Cement } \\
\hline & $0-1 \%$ & $1-10 \%$ & $10-50 \%$ & Over $50 \%$ & & $\begin{array}{c}\text { Sorting } \\
\text { Poor }\end{array}$ & $\begin{array}{l}\text { Sorting } \\
\text { Good }\end{array}$ & $\begin{array}{c}\text { Rounded \& } \\
\text { Abraded }\end{array}$ \\
\hline
\end{tabular}

\begin{tabular}{|c|c|c|c|c|}
\hline \multicolumn{2}{|c|}{ Allochthonous } & \multicolumn{3}{|c|}{ Autochthonous } \\
\hline \multirow{2}{*}{\multicolumn{2}{|c|}{$\begin{array}{c}\begin{array}{c}\text { Original components not } \\
\text { bound organically at } \\
\text { deposition }\end{array} \\
>10 \% \text { grains }>2 \mathrm{~mm} \\
\end{array}$}} & \multicolumn{3}{|c|}{$\begin{array}{l}\text { Original components bound } \\
\text { organically at deposition }\end{array}$} \\
\hline & & \multirow[b]{2}{*}{$\begin{array}{l}\text { By } \\
\text { organisms } \\
\text { that act as } \\
\text { baffles }\end{array}$} & \multirow[b]{2}{*}{$\begin{array}{c}\text { By } \\
\text { organisms } \\
\text { that encrust } \\
\text { and bind }\end{array}$} & \multirow[b]{2}{*}{$\begin{array}{l}\text { By } \\
\text { organisms } \\
\text { that build } \\
\text { ar igid } \\
\text { framework }\end{array}$} \\
\hline $\begin{array}{c}\text { Matrix } \\
\text { supported }\end{array}$ & $\begin{array}{c}\text { Supported } \\
\text { by }>22 m m \\
\text { component }\end{array}$ & & & \\
\hline Floatstone & Rudstone & Bafflestone & Bindstone & Framestone \\
\hline
\end{tabular}

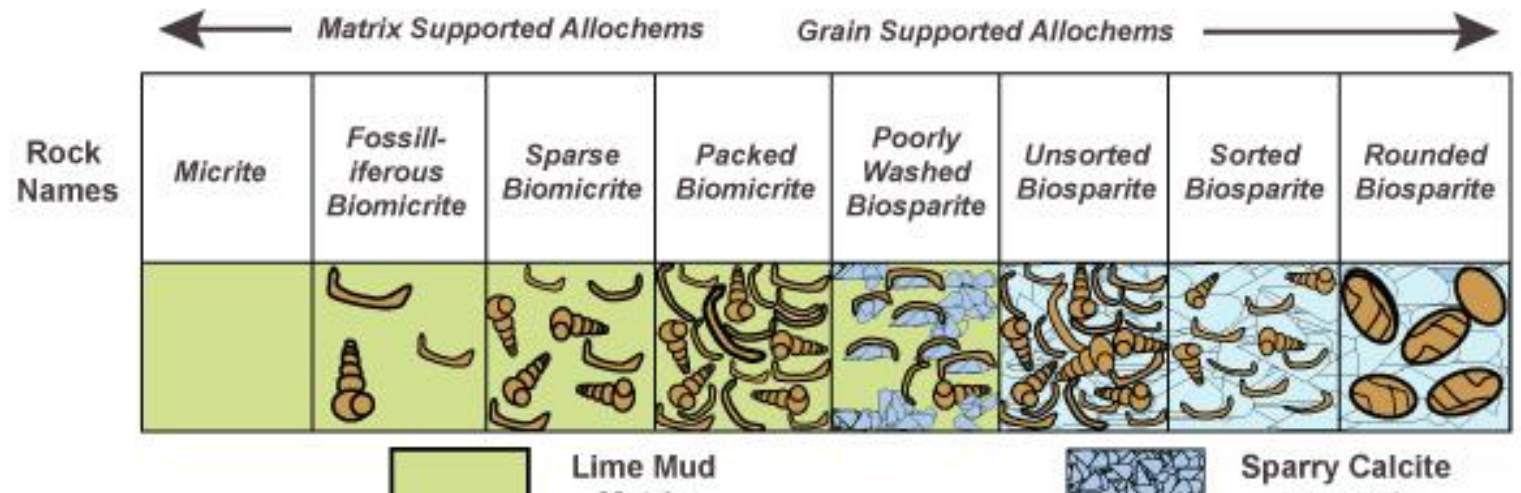

Matrix 


\section{Menelisik Arti "Gua"}

\subsection{Definisi Gua}

\begin{tabular}{|c|l|}
\hline $\begin{array}{c}\text { Alopsi } \\
\text { irtanah }\end{array}$ & $\begin{array}{l}\text { Definisi Saintifik: } \\
\text { Goa adalah lorong alami yang terbentuk pada batuan yang } \\
\text { berfungsi sebagai konduit untuk mengalirkan air dari suatu } \\
\text { titik input sampai pada suatu titik output mataair. Goa } \\
\text { berperan sebagai sistem aliran sekaligus pengatus dalam } \\
\text { hidrologi karst. Diameter yang disyaratkan adalah }>5 \mathrm{~mm} \text {, dan } \\
\text { sebagian yang lain mensyaratkan > 15 mm. Meskipun } \\
\text { demikian, ukurannya bisa saja sampai pada ukuran beberapa } \\
\text { puluh meter. Saluran serupa dengan ukuran diameter }<5 \mathrm{~mm} \\
\text { biasanya disebut sebagai protocave. }\end{array}$ \\
\hline (Perspektif Hidrologi Karst) & $\begin{array}{l}\text { Definisi non-Saintifik: } \\
\text { Goa adalah lorong alami yang terbentuk pada batuan dengan } \\
\text { ukuran yang cukup untuk dimasuki manusia. Ukuran ini } \\
\text { umumnya didefinisakan dengan batasan minimum diameter } \\
\text { sebesar } 30 \quad \mathrm{~cm} \text {. Definisi ini lebih menekankan pada } \\
\text { kemungkinan dilakukannya eksplorasi, pemetaan dan studi } \\
\text { secaralangsung di dalamnya. }\end{array}$ \\
\hline ahmadcahyadi@geo.ugm.ac.id
\end{tabular}




\section{Menelisik Arti "Gua"}

\subsection{Klasifikasi Gua}

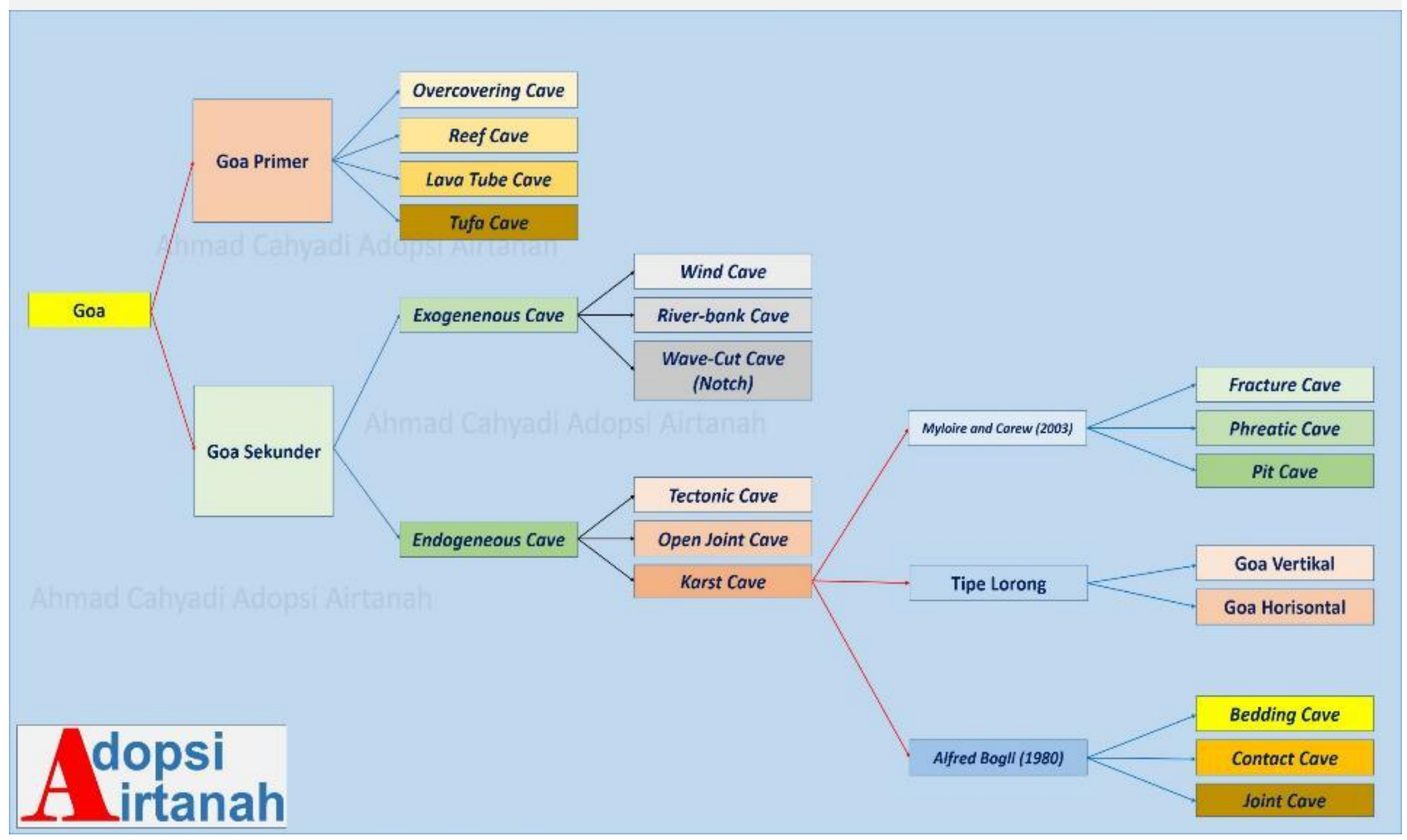




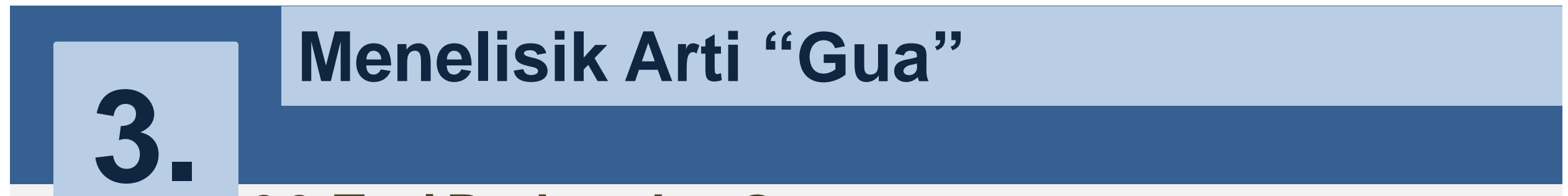

\subsection{Teori Pembentukan Gua}

(a) Davis

(1930)

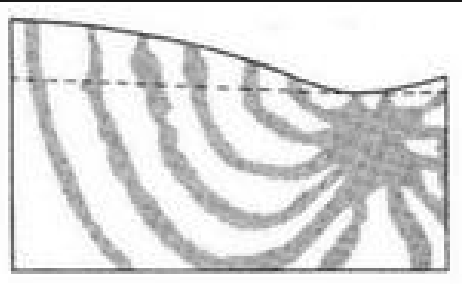

(b) Swinnerton

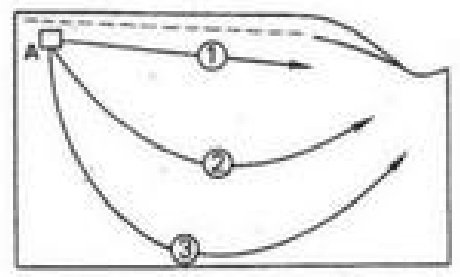

(c) Hubbert

(1940)

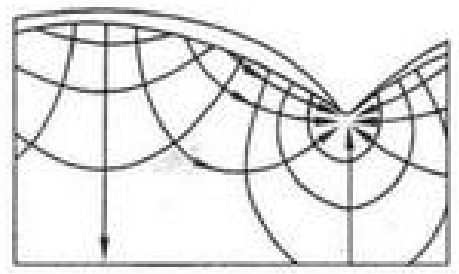

(d) Rhoades and
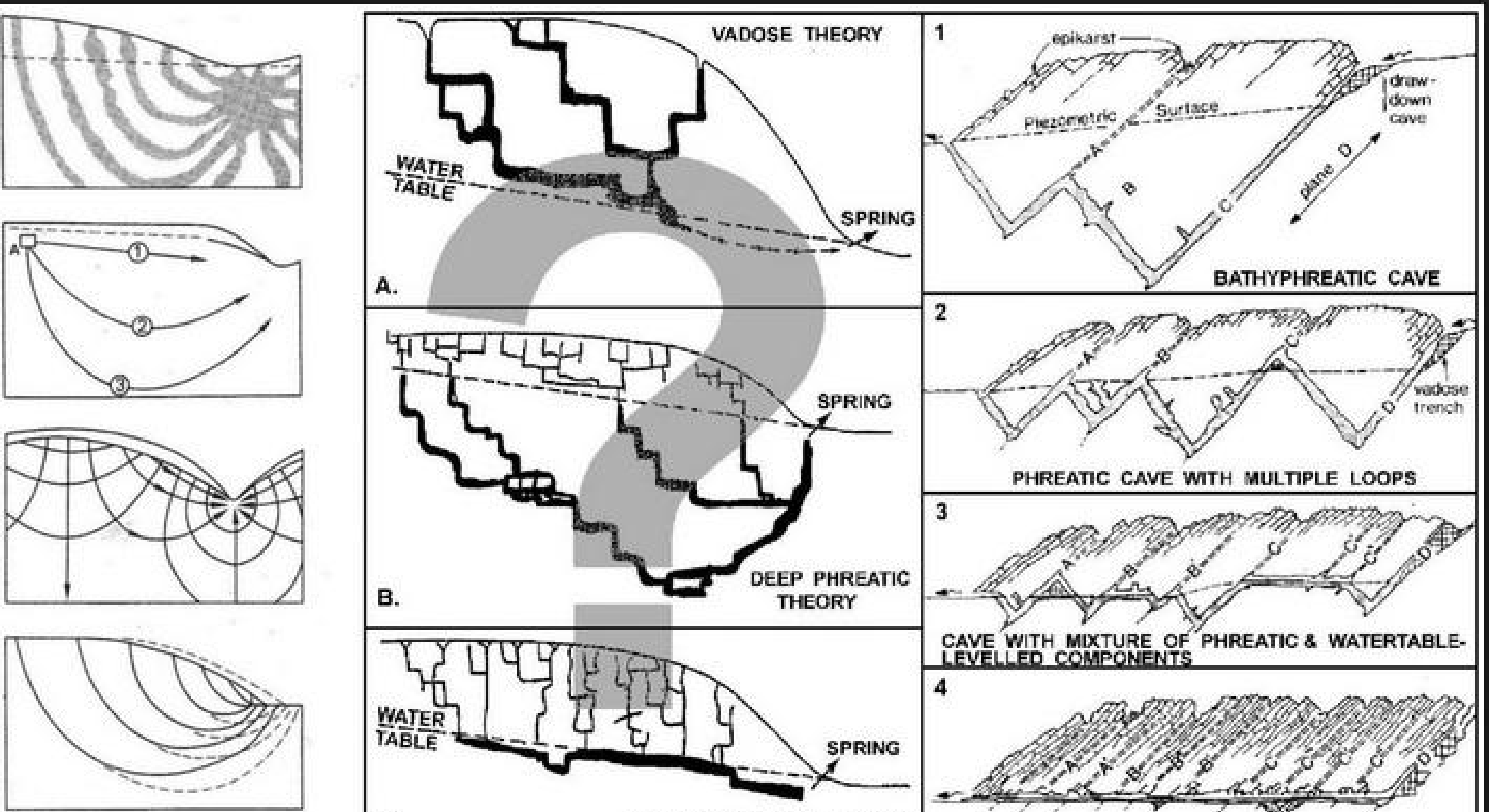
(1932) Sinacori (1941)
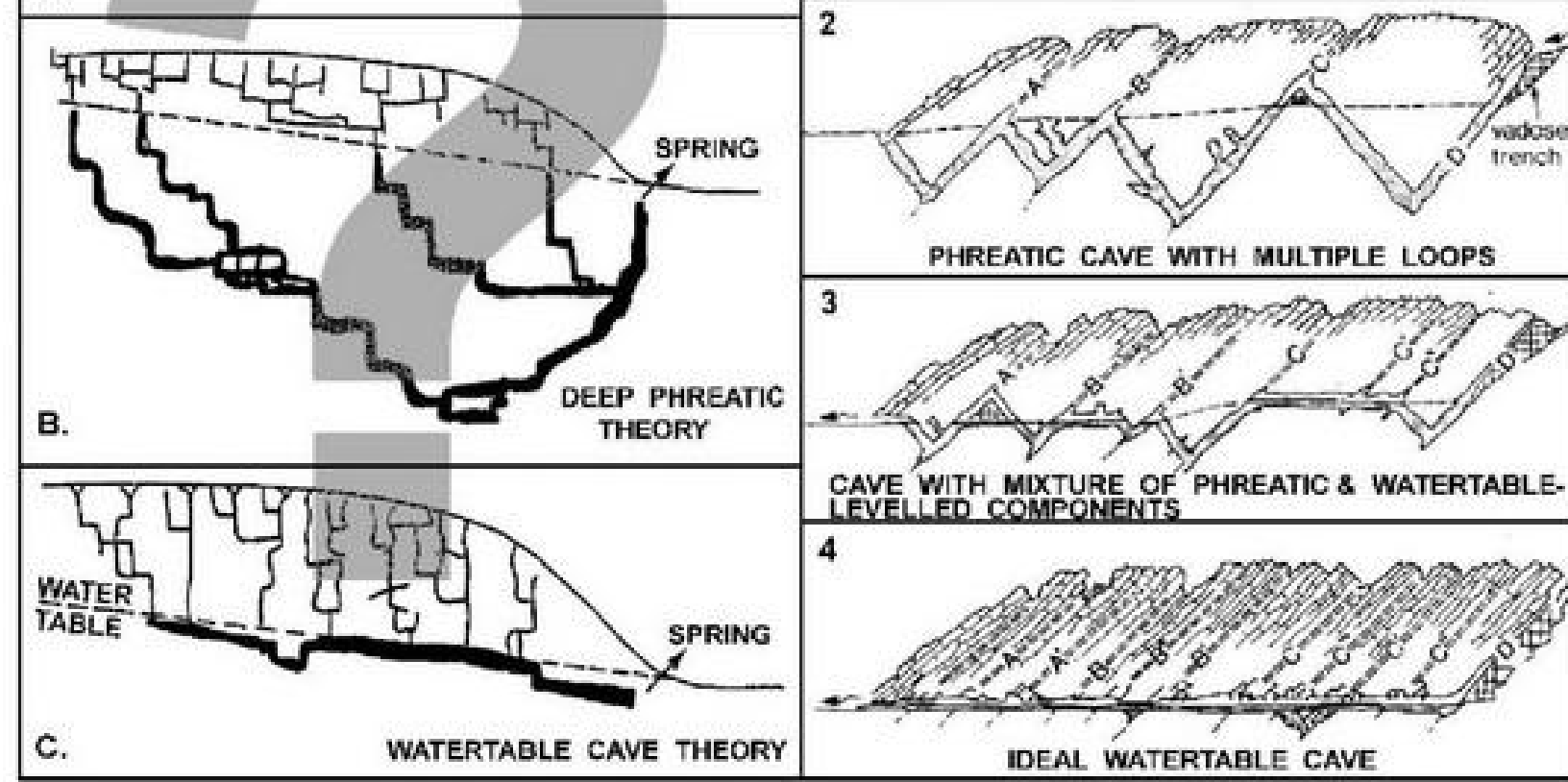

PHREATIC CAVE WITH MULTIPLE LOOPS

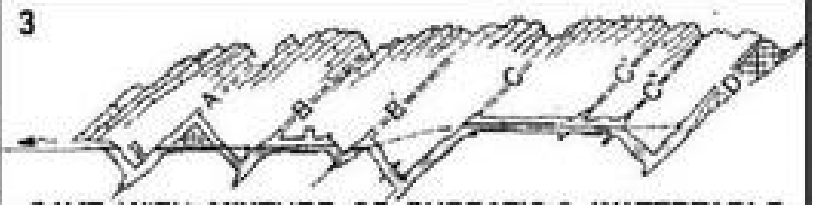

CAVE WITH MIXTURE OF PHREATIC \& WATERTABLELEVELLEO COMPONENTS

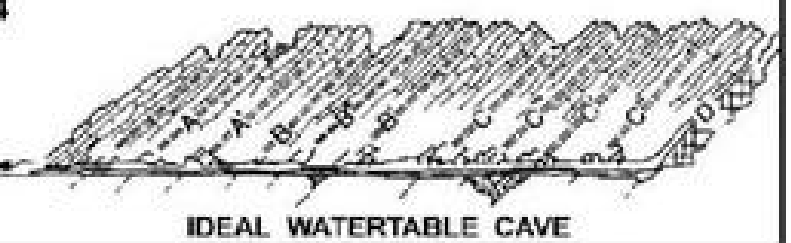

http://www.speleogenesis.info/community/blog/post/?id=Perspectives-on-the-Four-StateModel-of-cave-genesis 


\section{Menelisik Arti "Gua”}

\subsection{Evolusi Karst dan Pembentukan Gua}

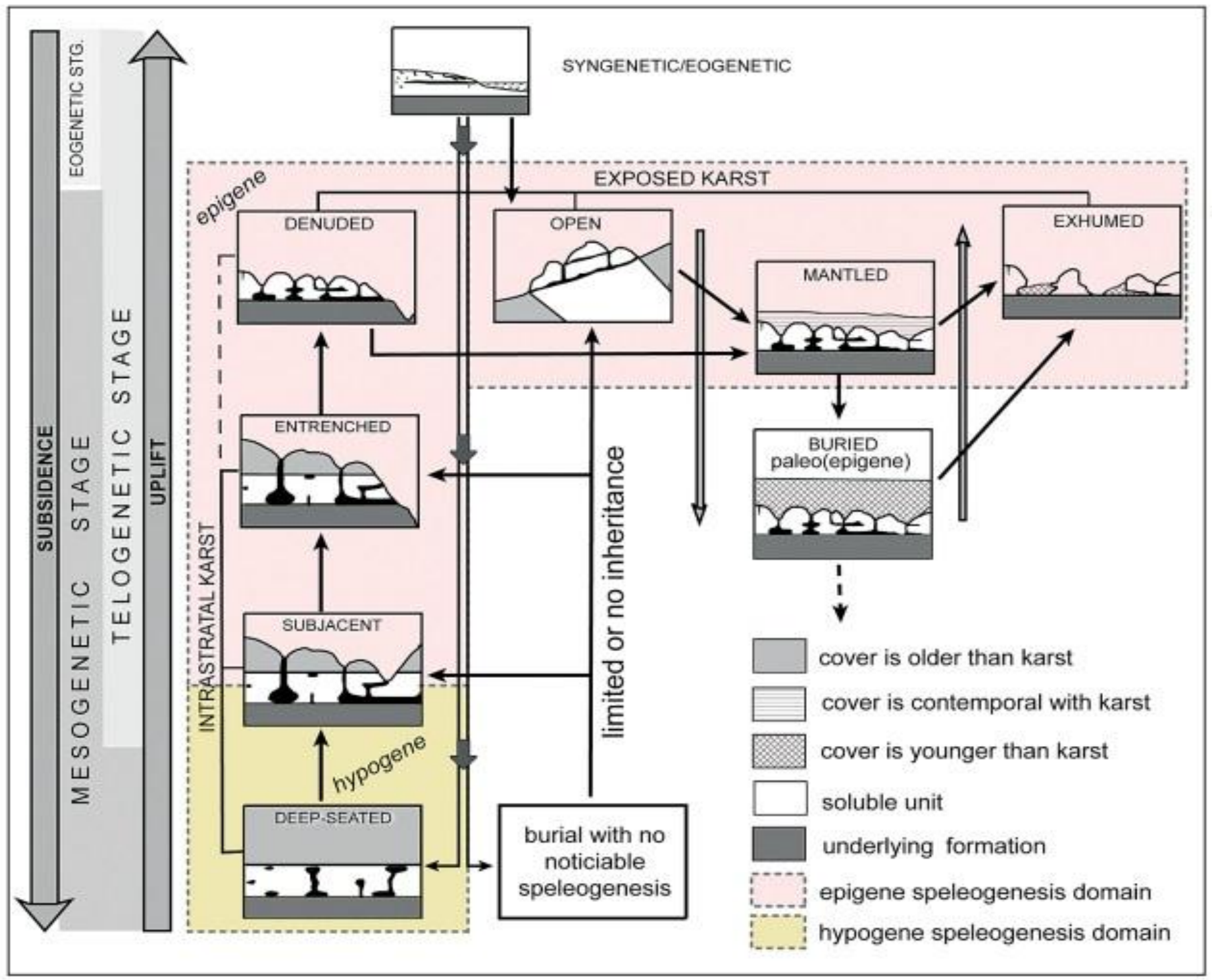

Fig. 4: Evolutionary types of karst and speleogenetic environments (modified from Klimchouk \& Ford 2000). Background colors indicate the domains of hypogene and epigene speleogenesis.

Sumber: Klimchouk (2015) 


\section{Menelisik Arti "Speleologi"}

4.1. Speleologi Ilmu tentang Gua

* Speleologi adalah ilmu tentang gua

* Keberadaannya sangat terkait dengan banyak disiplin ilmu, dan umumnya masing-masing disiplin ilmu memiliki ciri khas yang unik terkait dengan tema penelitian yang dilakukan

- Speleologi sebenarnya menjadi ilmu yang menyatukan banyak disiplin ilmu dengan tujuan yang sama, yakni "mengkonservasi gua" 


\section{Peranan Hidrologi dan Speleologi}

5.1. Karakterisasi Kawasan Karst I (Pemetaan Gua)

- Pemetaan gua memiliki peranan yang sangat penting dalam analisis sistem hidrologi kawasan karst;

- Pemetaan gua yang dimaksud tidak hanya berkaitan dengan lokasi mulut gua saja, tetapi juga pemetaan bentuk dan aspek keruangan dari lorong gua

* Pemetaan gua juga akan sangat membantu dalam analisis proses geologi dan geomorfologi yang terjadi dalam waktu lampau 


\section{Pemetaan Gua dan Mataair}

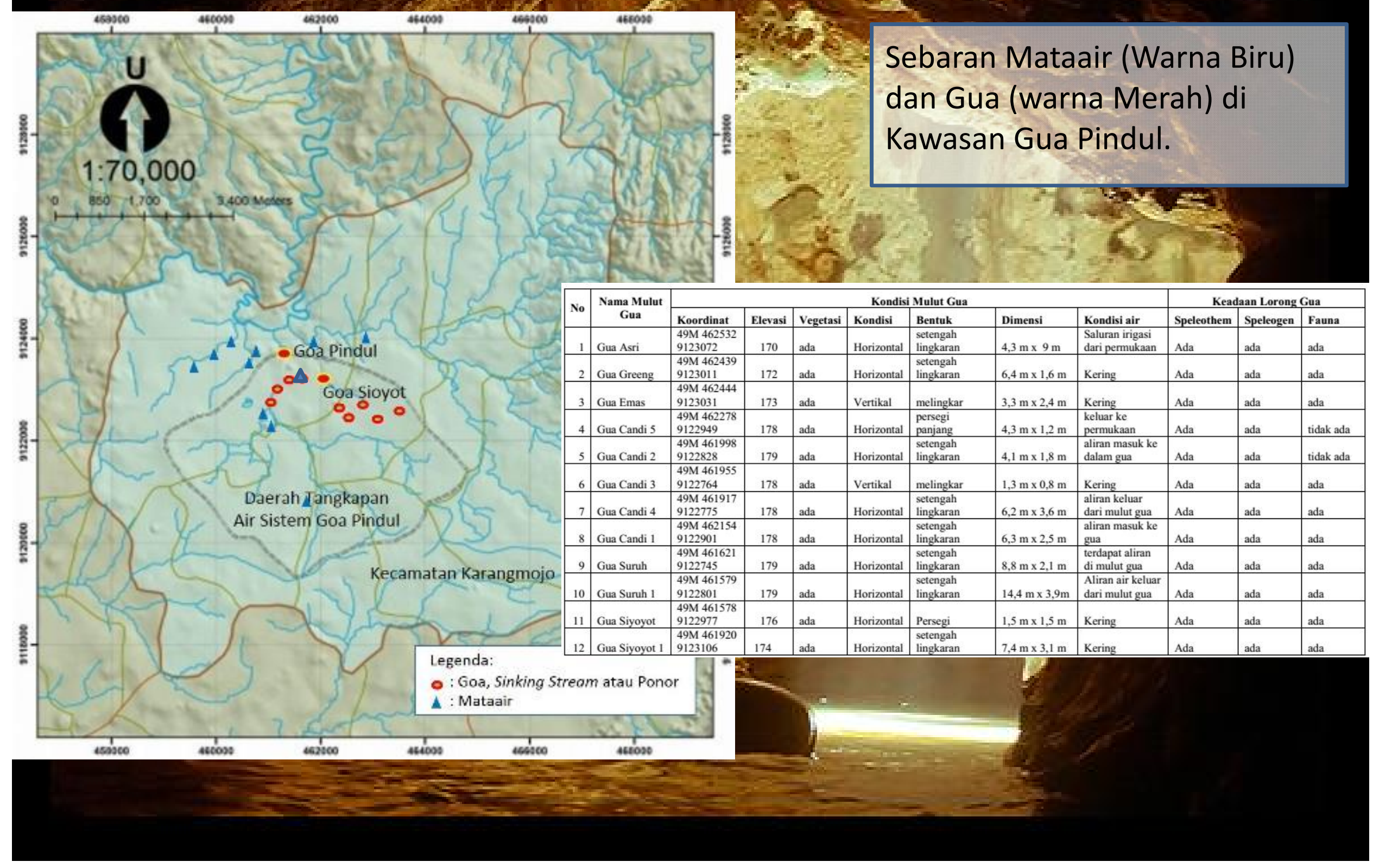




\section{Analisis Sistem SBT}

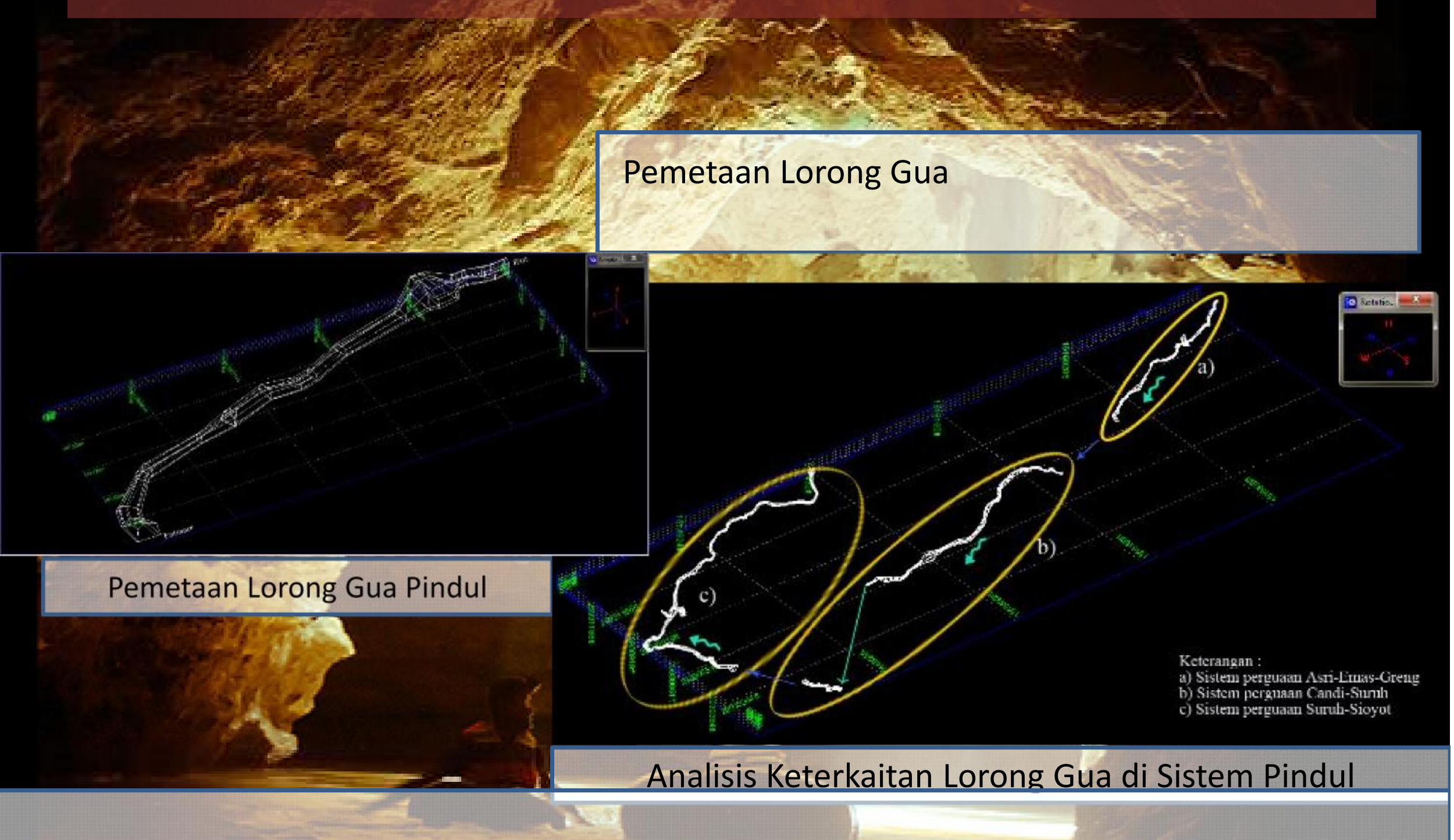

Diperkirakan terdapat 3 sistem Gua di kawasan Gua Pindul, yaitu: 1. Sistem Perguaan Asri-EmasGreng, 2. Sistem Perguaan Candi-Suruh, dan 3. Sistem Perguaan Suruh-Sioyot (Agniy, 2016) 


\section{Peranan Hidrologi dan Speleologi}

5.2. Karakterisasi Kawasan Karst II (Analisis Konektivitas)

- Analisis konektivitas seringkali tidak bias dilakukan hanya dengan pemetaan gua.

* Banyak kendala seperti lorong yang sempit, lorong penuh air dan medan yang sulit

* Metode yang dapat ditempuh di antaranya adalah tracing test atau uji perunutan dengan artificial tracing (zat atau larutan pelacak) 


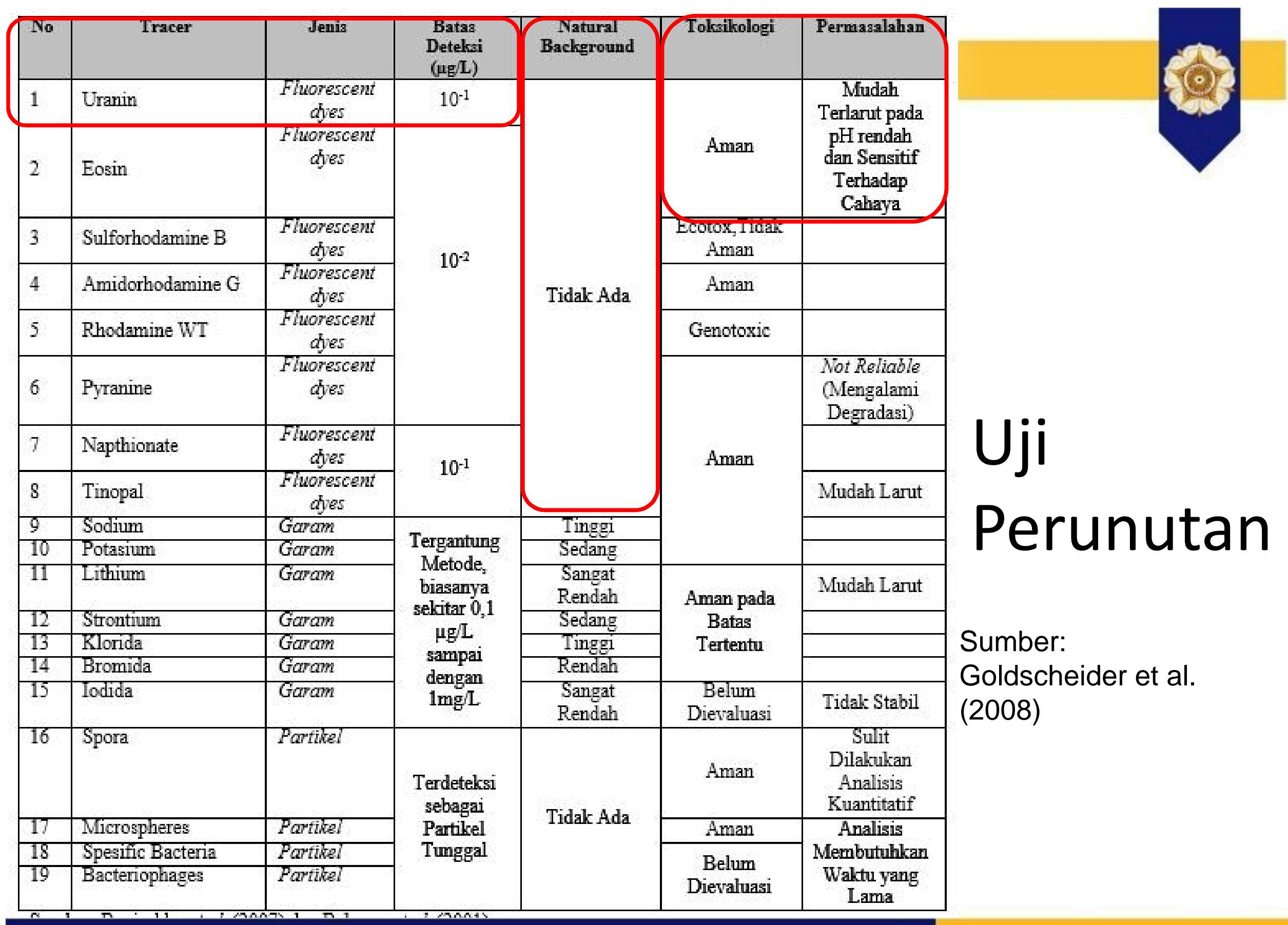




\section{Uji Perunutan}

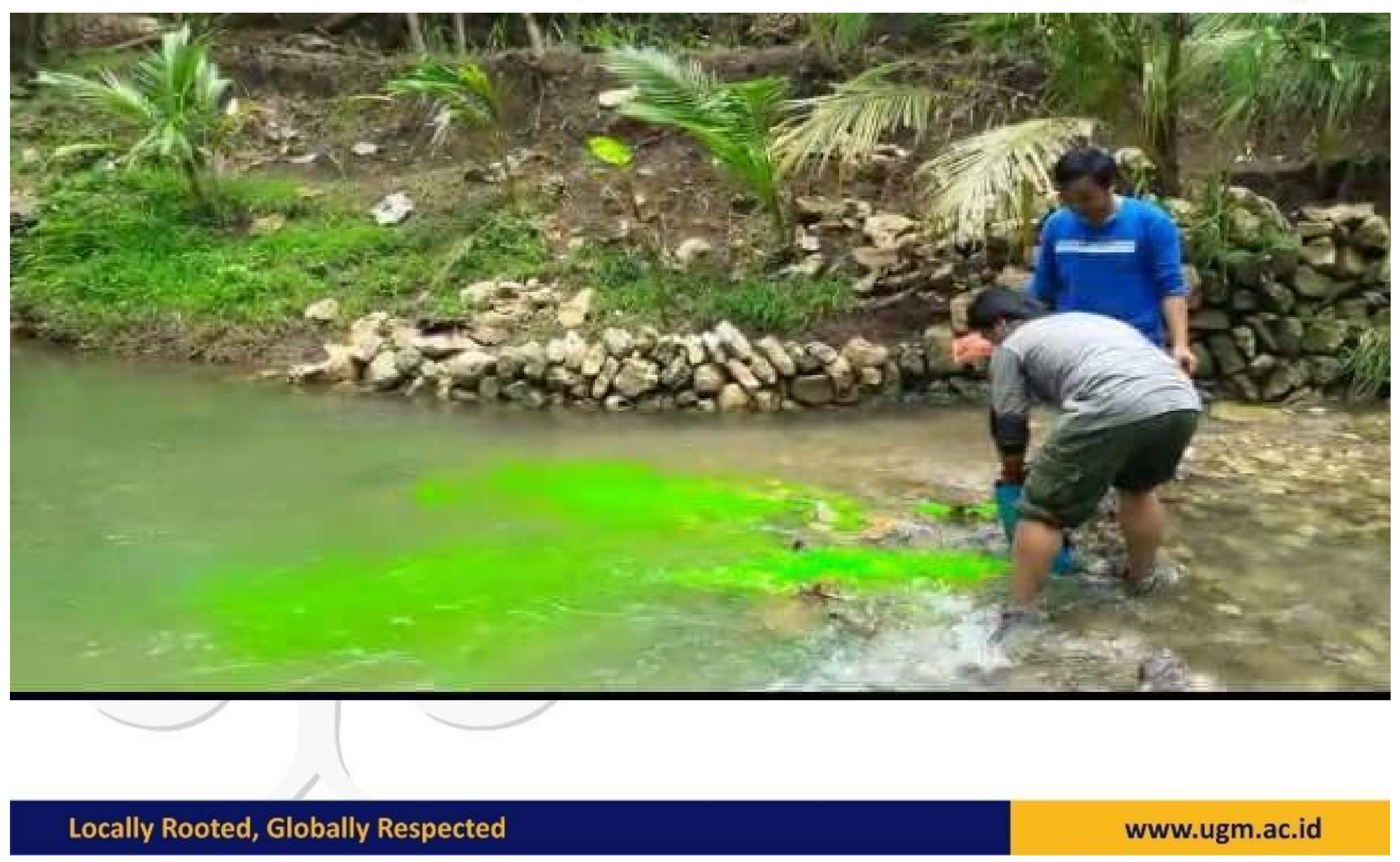




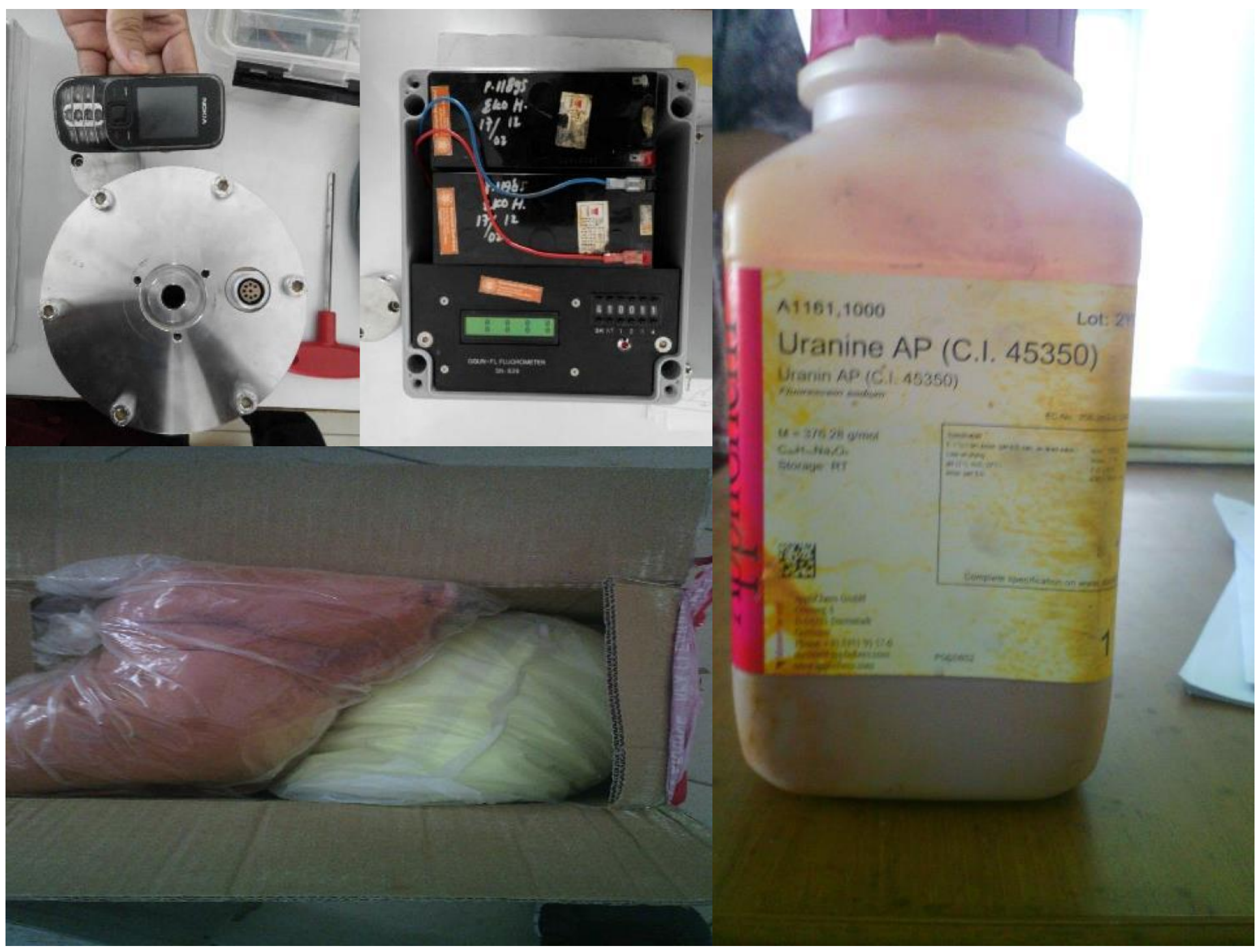




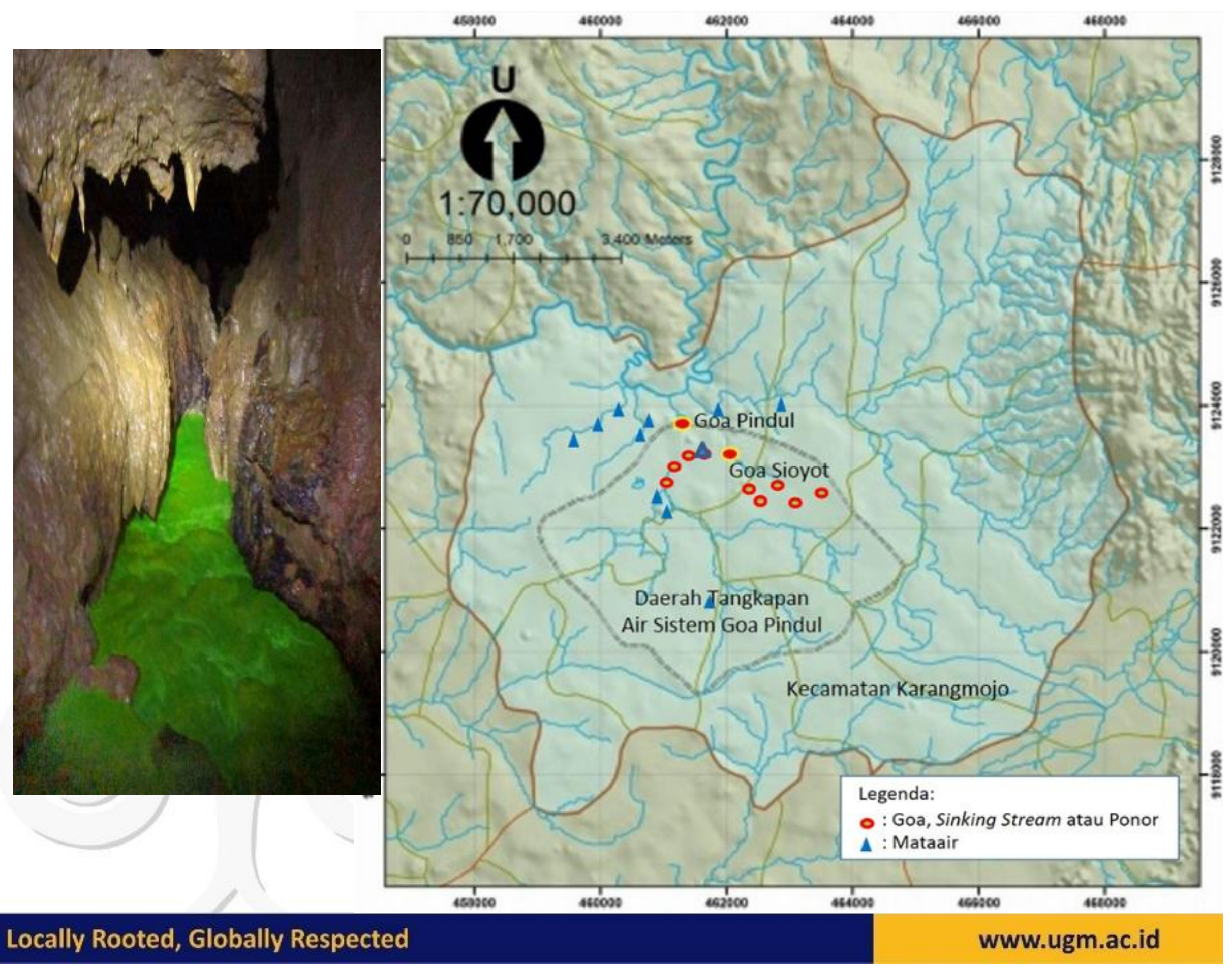




\section{Banyaknya Zat yang Digunakan}

$M=\mathbf{L} . \mathbf{k} . \mathbf{B}$

Keterangan:

$\mathrm{M}=$ Kuantitas zat Pelacak yang diperlukan $(\mathrm{Kg})$,

$\mathrm{k}=$ koefisien zat pelacak yang digunakan (nilai k untuk unranine adalah 1) dan

$\mathrm{B}=$ faktor kondisi hidrogeologi (biasanya bernilai $0,1-0,9$ ).

\begin{tabular}{llll}
\hline Tracer & $\mathrm{k}$ & Framework conditions & $\mathrm{B}$ \\
\hline Water soluble tracers: mass $[\mathrm{kg}]$ & & Surface streams & $0.1-0.9$ \\
$\quad$ Uranine & 1 & Karst aquifers (conduits) & \\
Eosin & 5.5 & Pure sand/gravel aquifers & \\
Sulforhodamine B & 4 & Highly fissured aquifers & \\
Amidorhodamine G & 2 & Impure sand/gravel aquifers & $2-4$ \\
Pyranine & 5.5 & Injection into groundwater & \\
Naphthionate & 15 & through unsaturated zone & \\
Tinopal & 3 & Karst aquifers (matrix), & \\
NaCl & 20000 & Poorly fissured aquifers & \\
LiCl & 1000 & River bank filtration & \\
KCl & 10000 & Turbid sampling water or & \\
Particle tracers: number of particles & & tracer background level >0 & \\
Microspheres & $1 \mathrm{E}+12$ & Injection through thick or & $5-10$ \\
Bacteriophages & $1 \mathrm{E}+13$ & loamy unsaturated zone & \\
Bacteria (Serratia marcescens) & $1 \mathrm{E}+13$ & High clay/silt contents & \\
\hline
\end{tabular}

Sumber: Goldscheider et al. (2008) 

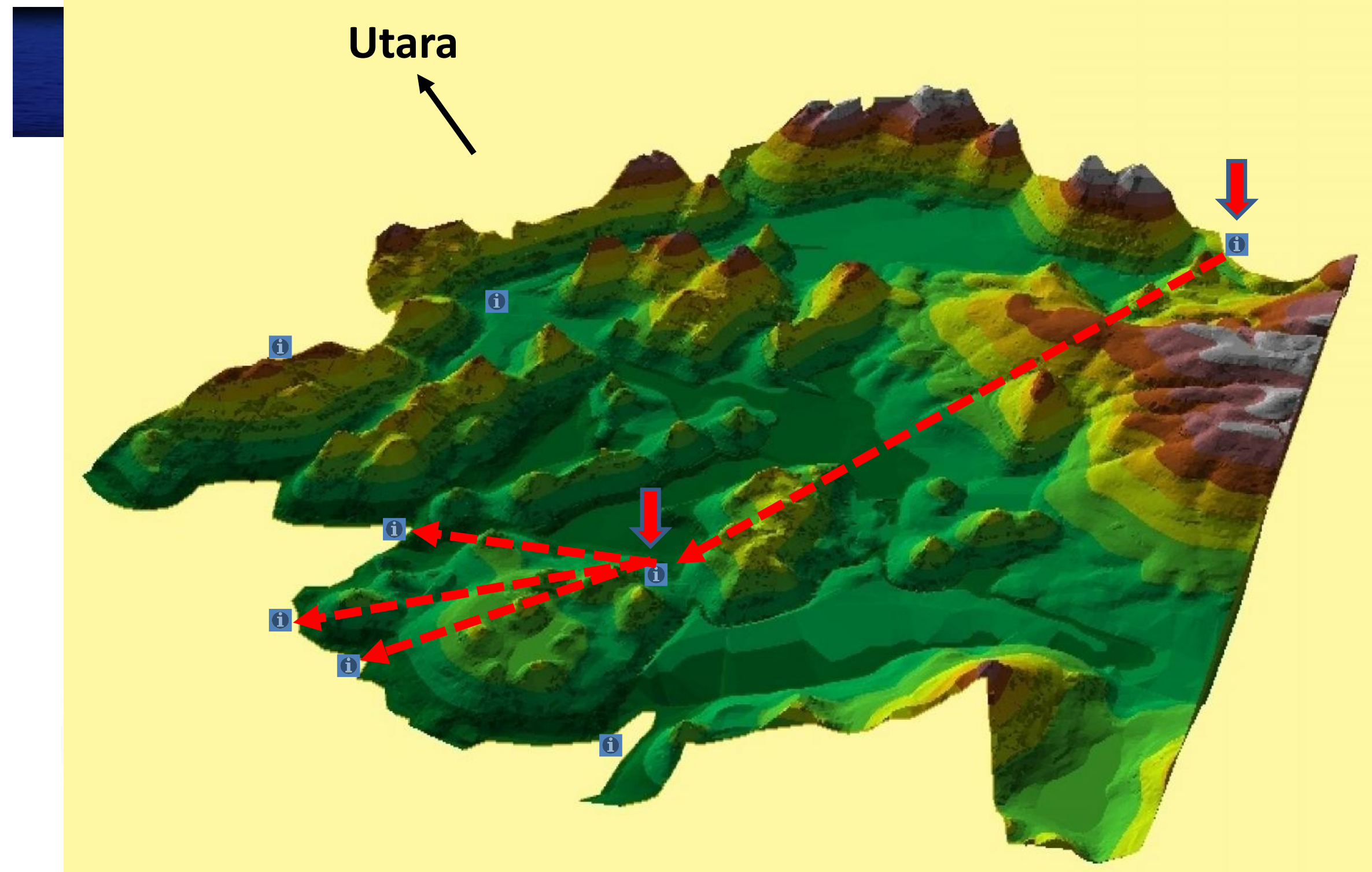


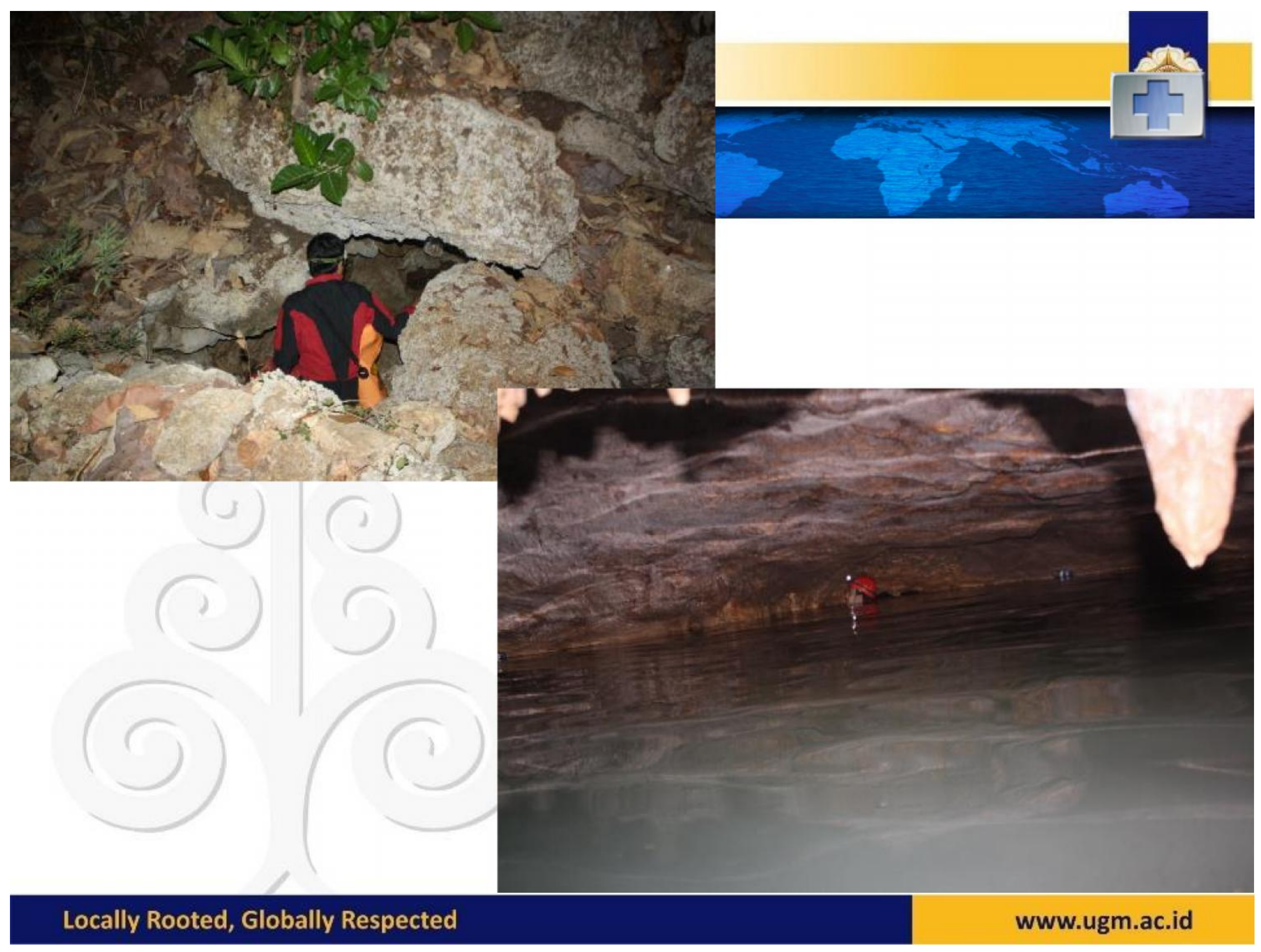




\section{Sistem Hidrologi DTA Pindul}

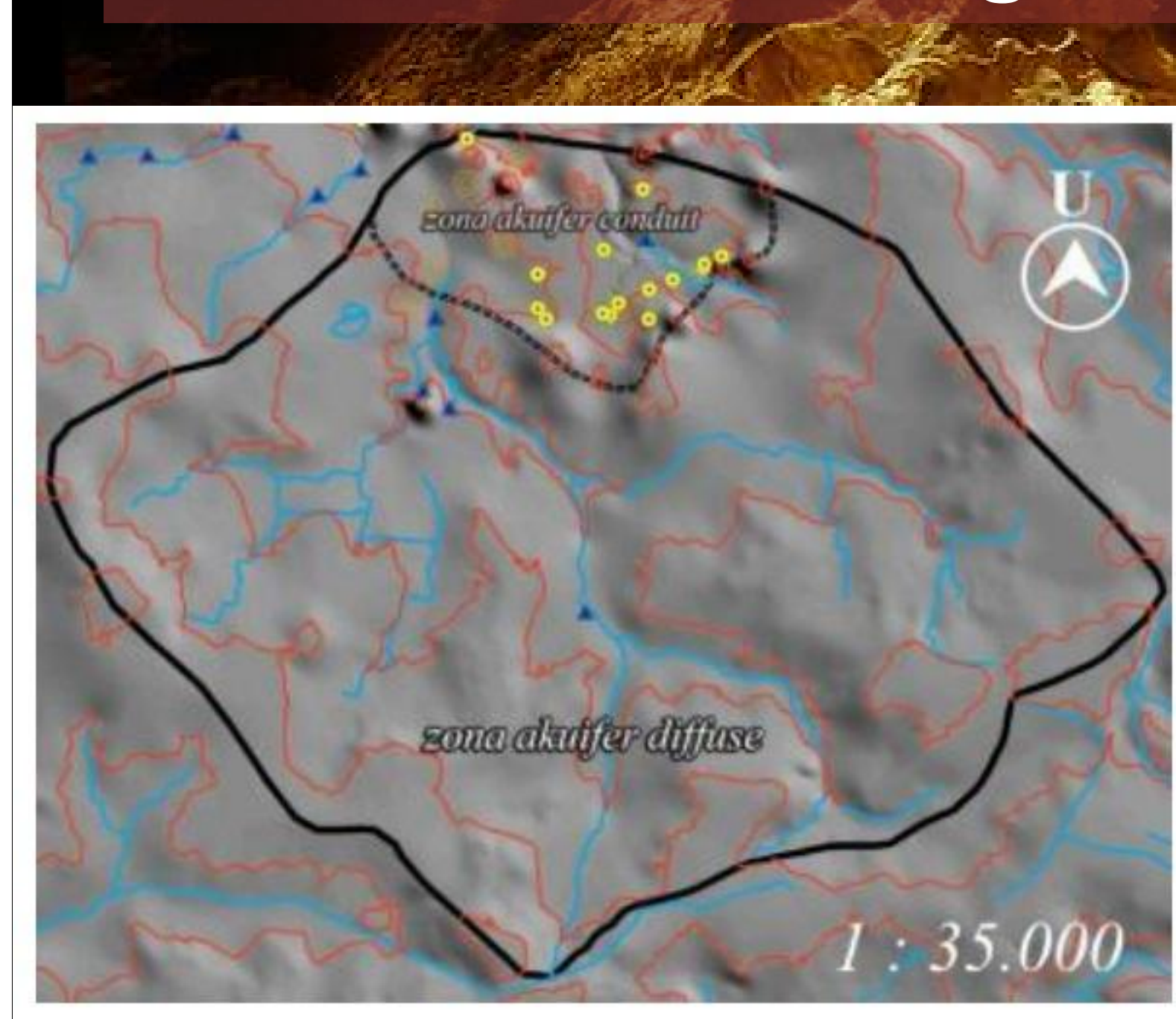

Berdasarkan delineasi daerah tangkapan permukaan Sistem Pindul dengan pendekatan topografi, dapat dibedakan menjadi 2 zona akuifer, yakni zona akuifer conduit (didominasi pelorongan/goa) di sebelah utara yang ditunjukkan dengan ditemukannya jaringan sistem perguaan dan zona akuifer diffuse (didominasi oleh aliran airtanah antar butir) di sebelah selatan yang dicirikan dengan belum berkembangnya jaringan sistem perguaan.

Daerah tangkapan permukaan Sistem Pindul dengan pendekatan topografi seluas $15,44 \mathrm{~km}^{2}$, zona akuifer conduit seluas $1,75 \mathrm{~km}^{2}$, dan zona akuifer diffuse seluas $13,69 \mathrm{~km}^{2}$. 


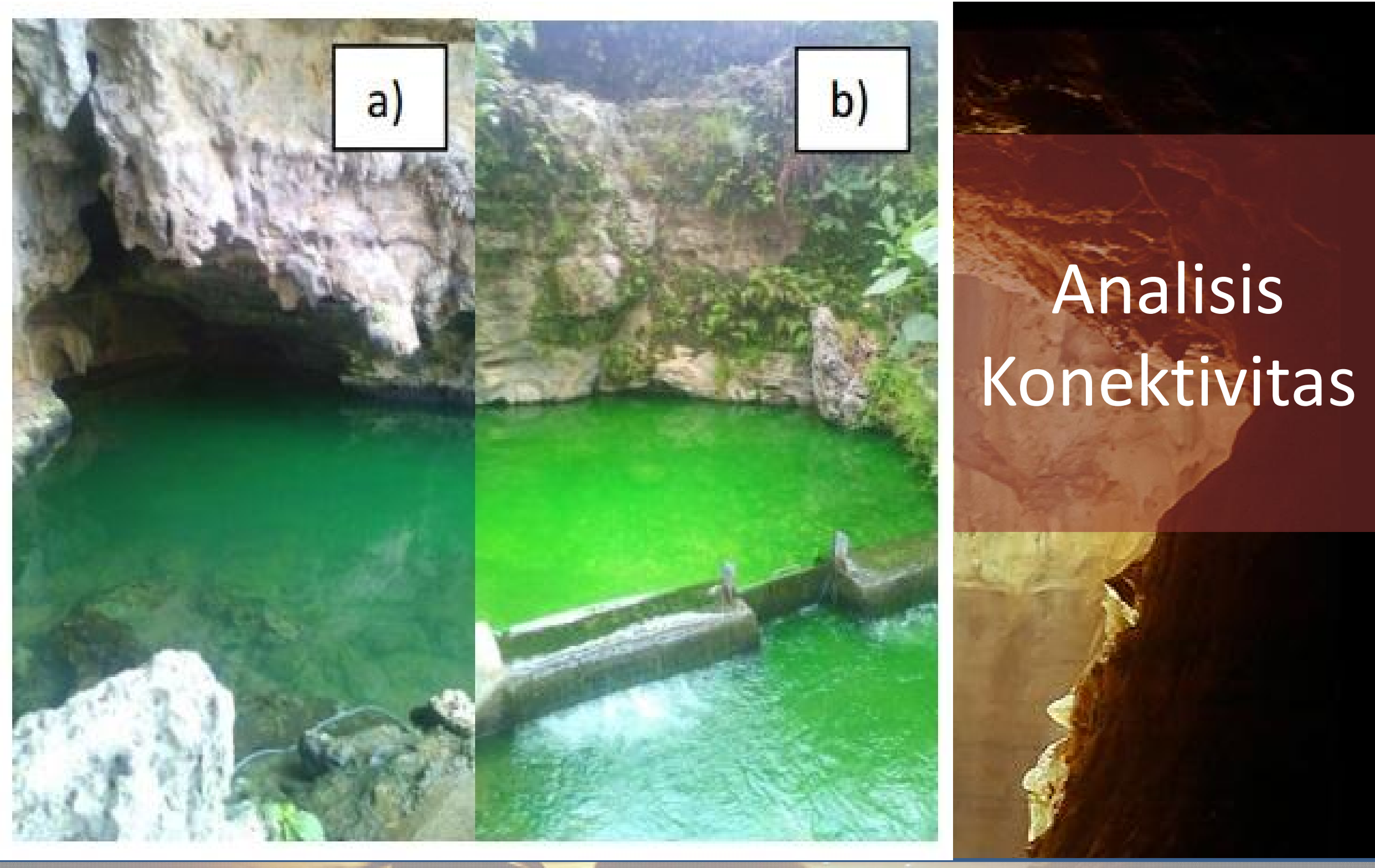

Hasil Dye Tracer menunjukkan cairan uranin keluar pada Sungai Bawah Tanah Pindul (a) setelah sebelumnya keluar pula di Mataair Ngancar (b) Sumber: Cahyadi dan Agniy (2016) 


\section{Analisis Konektivitas Sistem SBT}

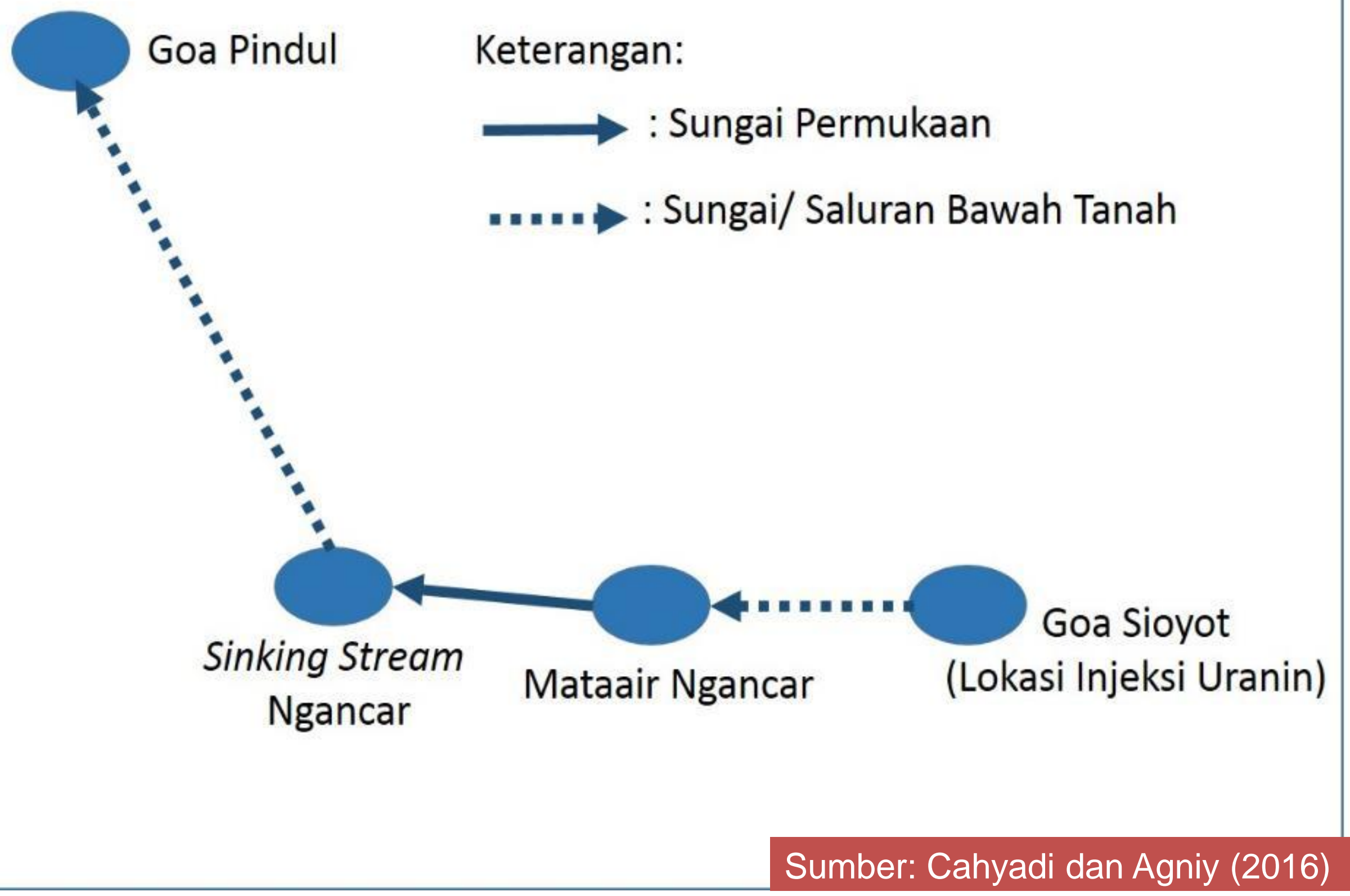




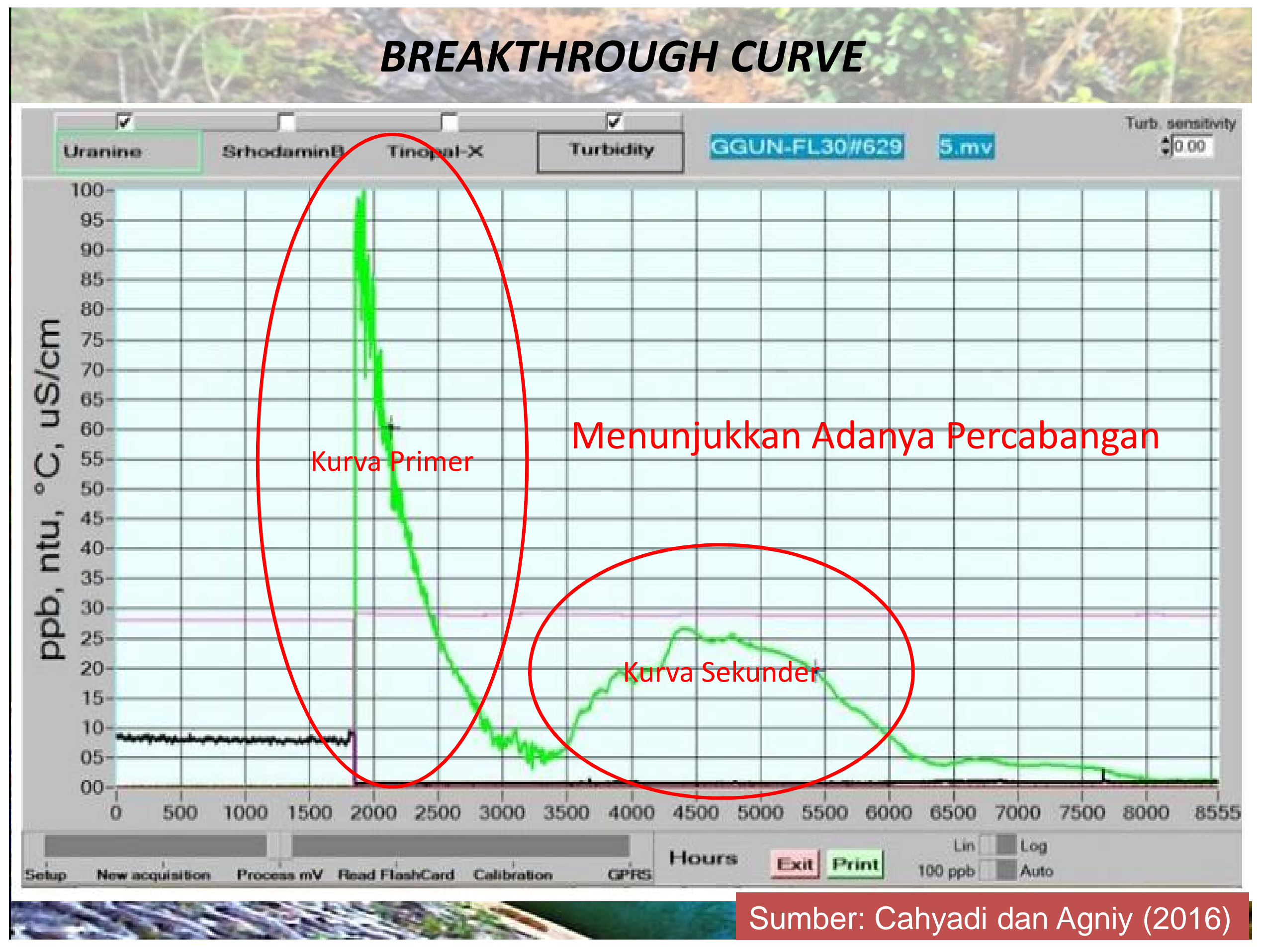




\section{BREAKTHROUGH CURVE}

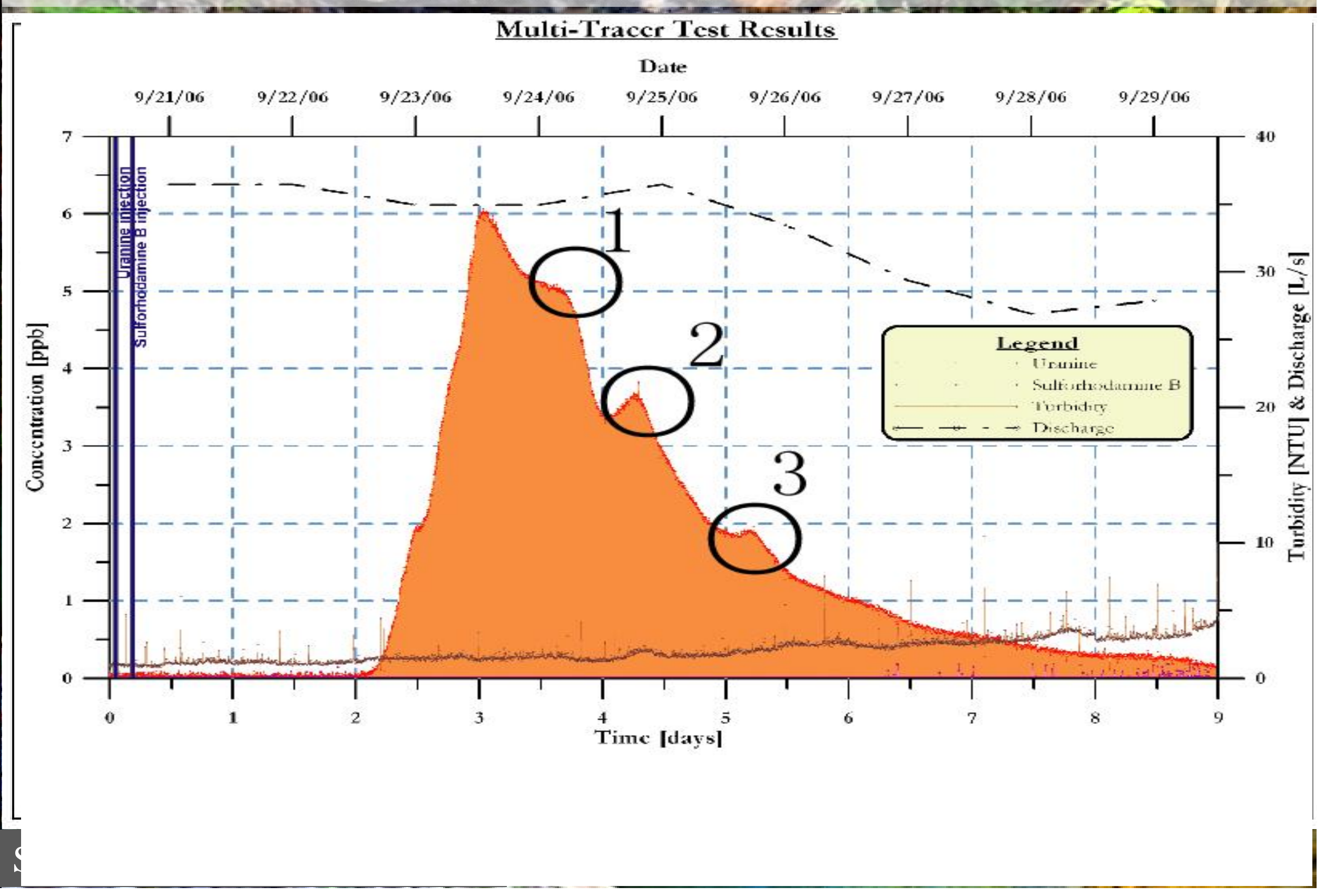




\section{BREAKTHROUGH CURVE}

A

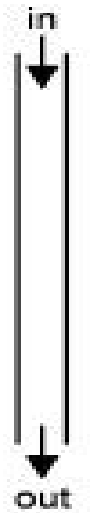

$Q_{\text {in }}=Q_{\text {out }}$

$M_{\text {in }}=M_{\text {out }}$

no dilution no divergence

G

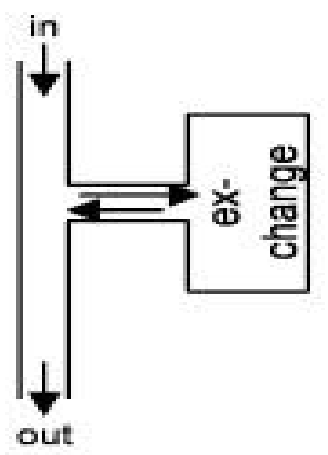

$Q_{\text {in }}=Q_{\text {out }}$

$M_{\text {in }}=M_{\text {out }}$

no dilution no divergence

exchange
B

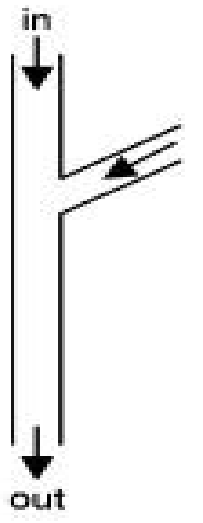

$Q_{\text {in }} \leq Q_{\text {out }}$

$M_{\text {in }}=M_{\text {out }}$

dilution convergence

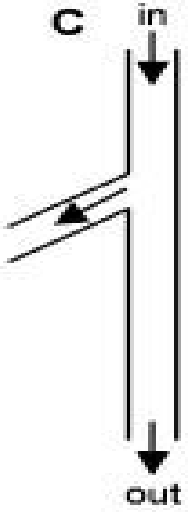

$\mathrm{Q}_{\text {in }} \geq \mathrm{Q}_{\text {out }}$

$M_{\text {in }} \geq M_{\text {out }}$

divergence no dilution

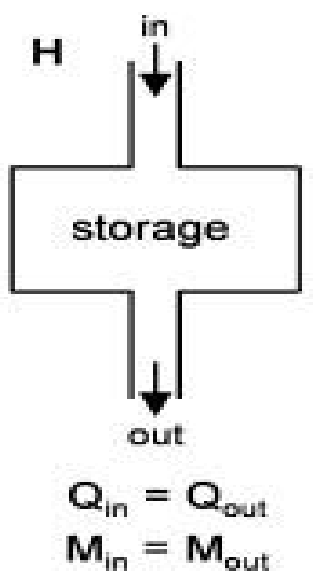

no dilution no divergence storage
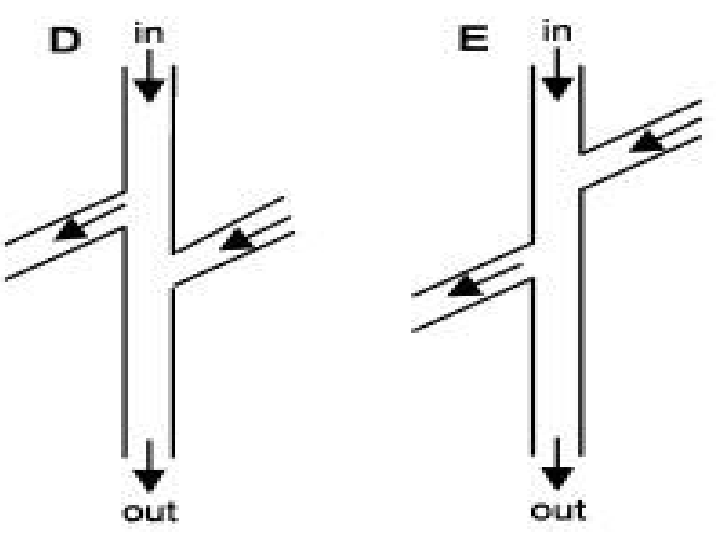

$$
\begin{aligned}
& Q_{\text {in }} \neq Q_{\text {out }} \\
& M_{\text {in }} \geq M_{\text {out }}
\end{aligned}
$$

divergence convergence dilution

$M_{\text {in }} \geq M_{\text {out }}$

convergence divergence dilution

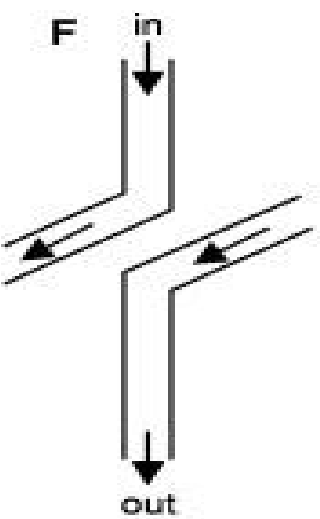

$Q_{\text {in }} \neq Q_{\text {out }}$

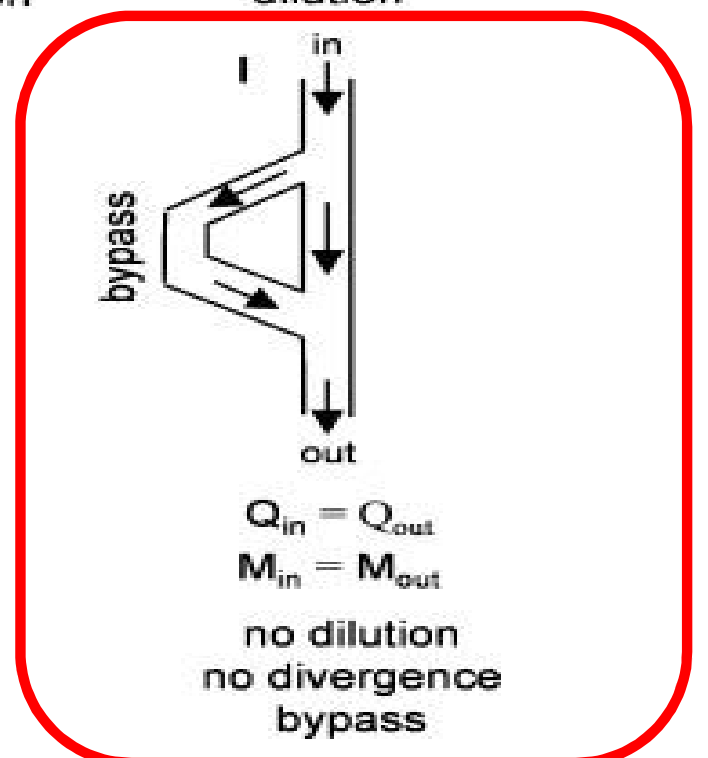

Sumber: Goldscheider et al. (2008) 


\section{BREAKTHROUGH CURVE}

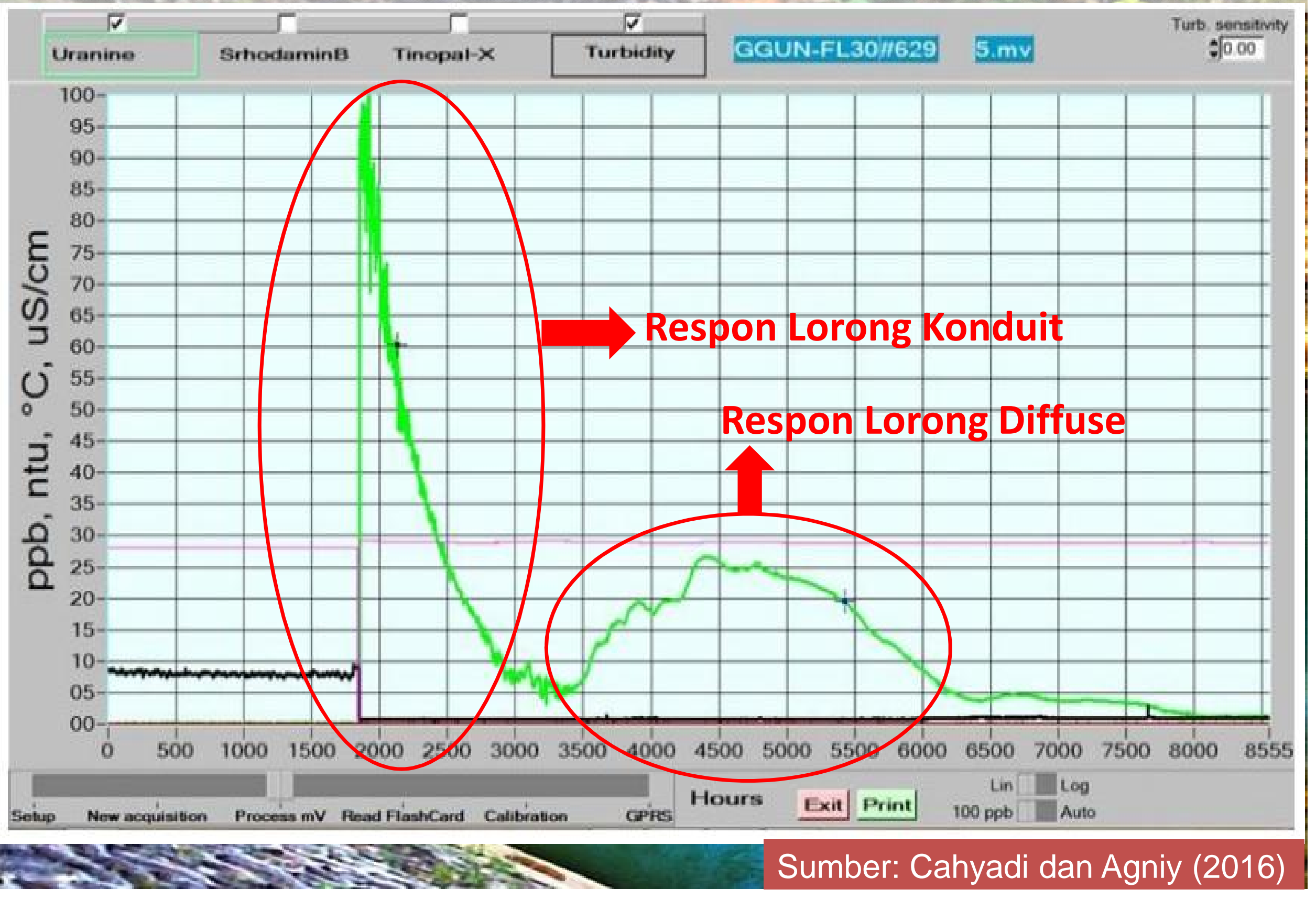




\section{Peranan Hidrologi dan Speleologi}

5.3. Karakterisasi Kawasan Karst III (Karakterisasi Hidrologi)

Spring Catchment

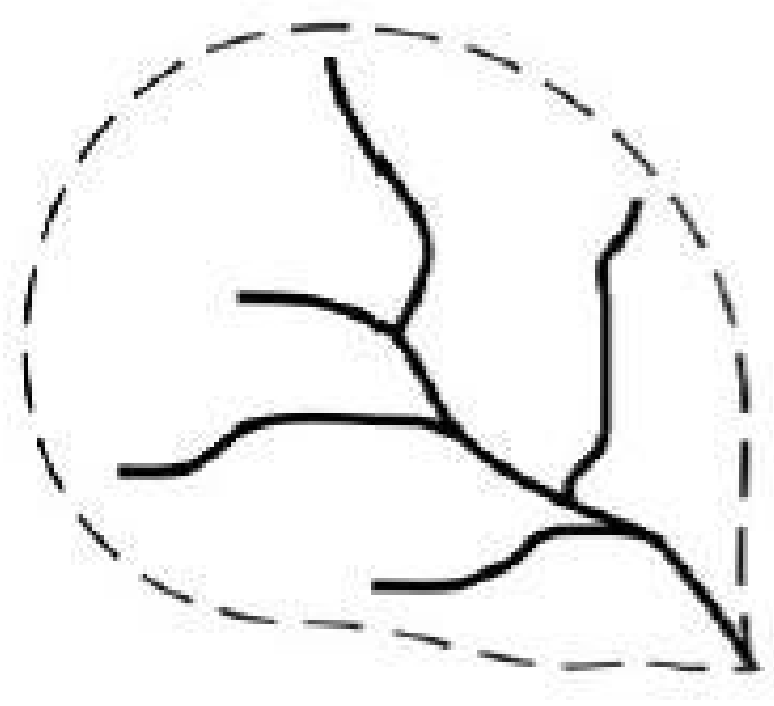

Forward Modelling
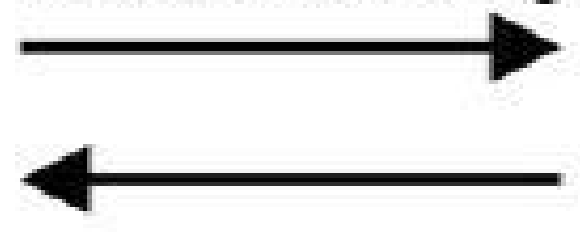

Inverse Modelling
Spring Response

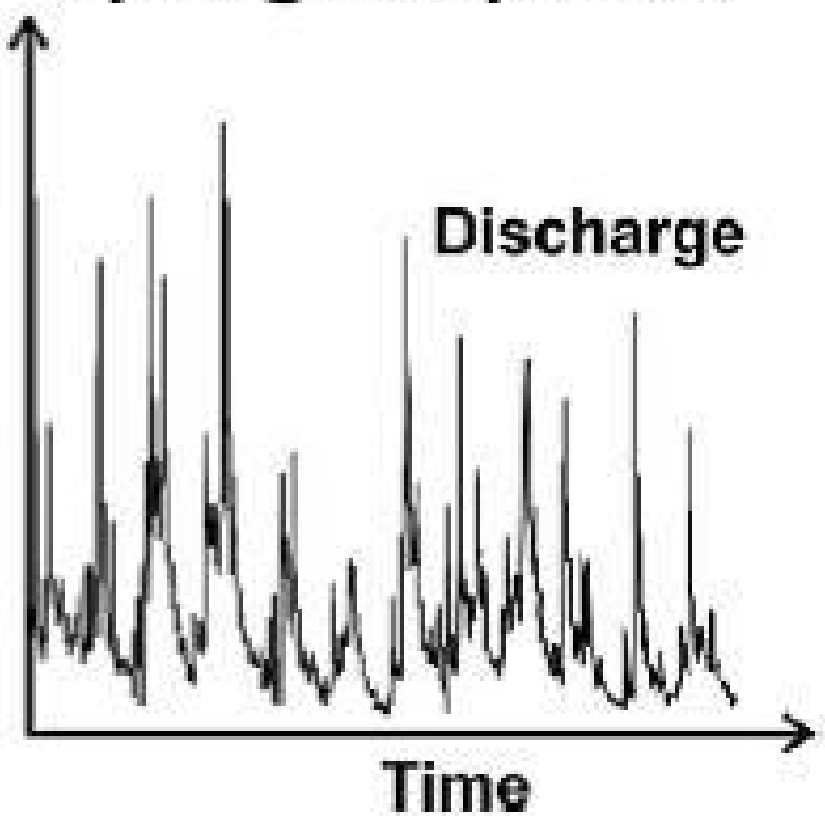

Sumber: Rehrl dan Birk (2010) 


\section{Peranan Hidrologi dan Speleologi}

5.3. Karakterisasi Kawasan Karst III (Karakterisasi Hidrologi)
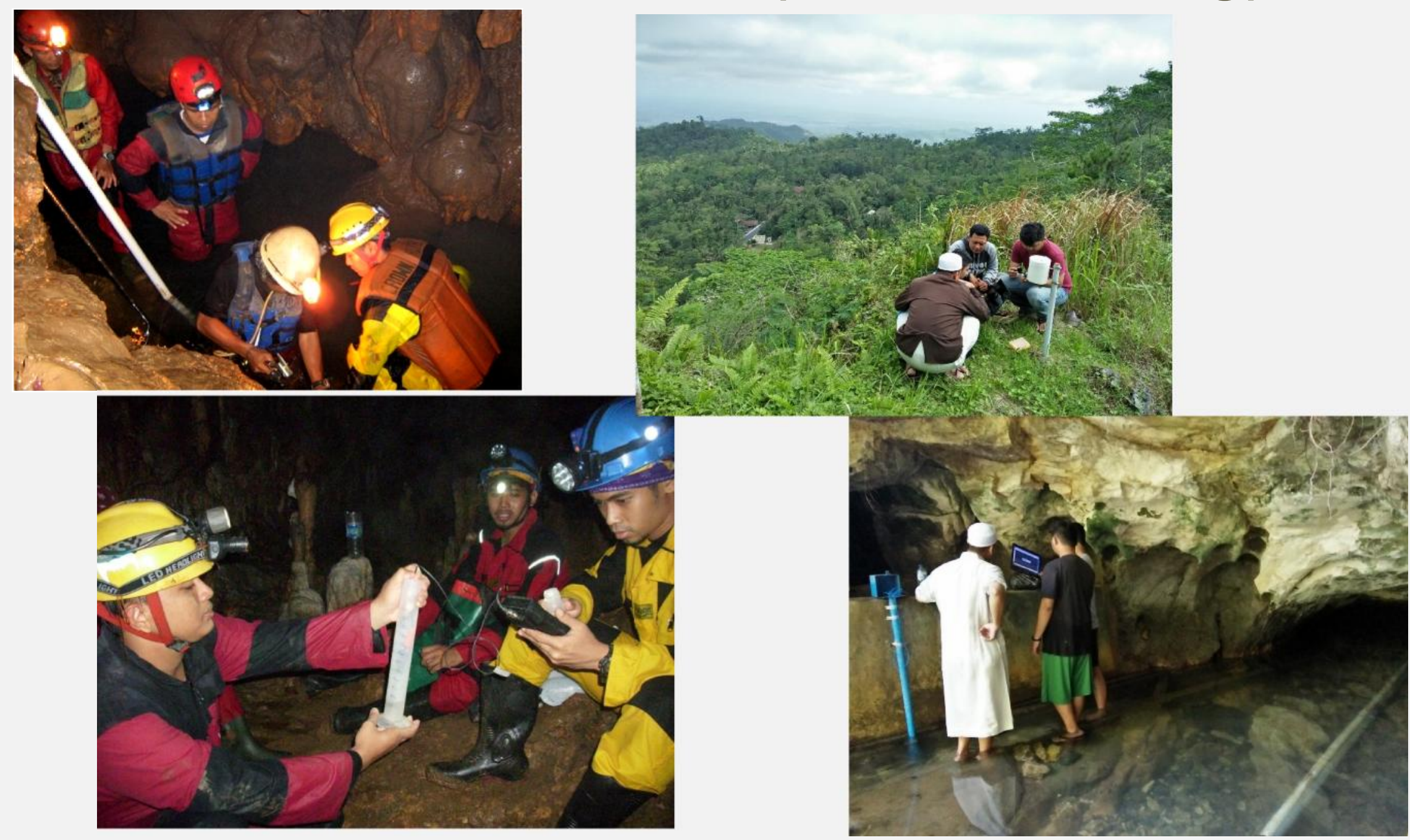


\section{Peranan Hidrologi dan Speleologi}

5.3. Karakterisasi Kawasan Karst III (Karakterisasi Hidrologi)

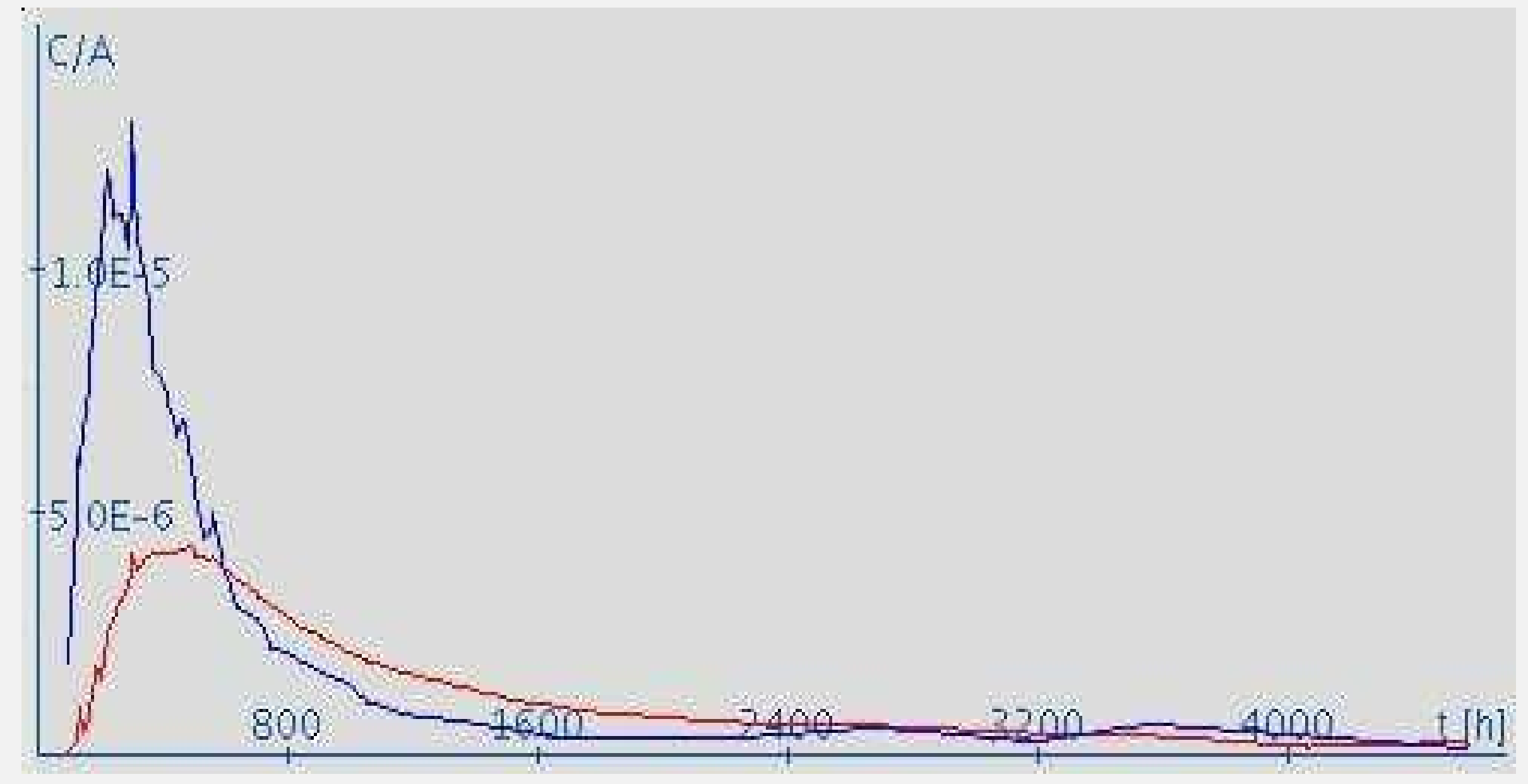




\section{Peranan Hidrologi dan Speleologi}

5.3. Karakterisasi Kawasan Karst III (Karakterisasi Hidrologi)

\begin{tabular}{|c|c|c|c|c|c|c|c|}
\hline Stasiun & Eksisting & $\begin{array}{l}\text { Tahun } \\
\text { 2020an }\end{array}$ & Perubahan (\%) & $\begin{array}{l}\text { Tahun } \\
\text { 2050an }\end{array}$ & Perubahan (\%) & $\begin{array}{l}\text { Tahun } \\
\text { 2080an }\end{array}$ & Perubahan (\%) \\
\hline Babadan & 2.982 & 2.803 & $-6,00$ & 3.164 & 12,88 & 4.308 & 36,16 \\
\hline Borobudur & 2.311 & 2.272 & $-1,69$ & 2.685 & 18,18 & 4.215 & 56,98 \\
\hline Dukun & 2.250 & 2.247 & $-0,13$ & 2.608 & 16,07 & 3.635 & 39,38 \\
\hline Jumprit & 2.573 & 2.577 & 0,16 & 2.648 & 2,76 & 3.390 & 28,02 \\
\hline Kaliangkrik & 3.650 & 3.468 & $-4,99$ & 3.847 & 10,93 & 4.389 & 14,09 \\
\hline Kintelan & 3.140 & 3.246 & 3,38 & 3.061 & $-5,70$ & 2.812 & $-8,13$ \\
\hline Magelang & 2.967 & 3.298 & 11,16 & 3.152 & $-4,43$ & 3.633 & 15,26 \\
\hline Parakan & 1.955 & 2.093 & 7,06 & 1.904 & $-9,03$ & 1.813 & $-4,78$ \\
\hline Cebongan & 2.579 & 2.842 & 10,20 & 2.617 & $-7,92$ & 2.559 & $-2,22$ \\
\hline Kalijoho & 1.857 & 1.812 & $-2,42$ & 1.761 & $-2,81$ & 1.818 & 3,24 \\
\hline Bronggang & $2 . .365$ & 2.499 & 5,67 & 2.509 & 0,40 & 2.362 & $-5,86$ \\
\hline Dolo & 2.004 & 1.916 & $-4,39$ & 1.987 & 3,71 & 1.984 & $-0,15$ \\
\hline Gandok & 2.083 & 1.938 & $-6,96$ & 1.982 & 2,27 & 2.048 & 3,33 \\
\hline Jangkang & 1.938 & 2.007 & 3,56 & 2.277 & 13,45 & 2.546 & 11,81 \\
\hline Pakem & 2.353 & 2.637 & 12,07 & 2.465 & $-6,52$ & 2.440 & $-1,01$ \\
\hline Pundong & 1.847 & 1.680 & $-9,04$ & 1.752 & 4,29 & 2.097 & 19,69 \\
\hline
\end{tabular}

Sumber: Cahyadi dkk. (2016) 


\section{Peranan Hidrologi dan Speleologi}

\subsection{Karakterisasi Kawasan Karst III (Karakterisasi Hidrologi)}
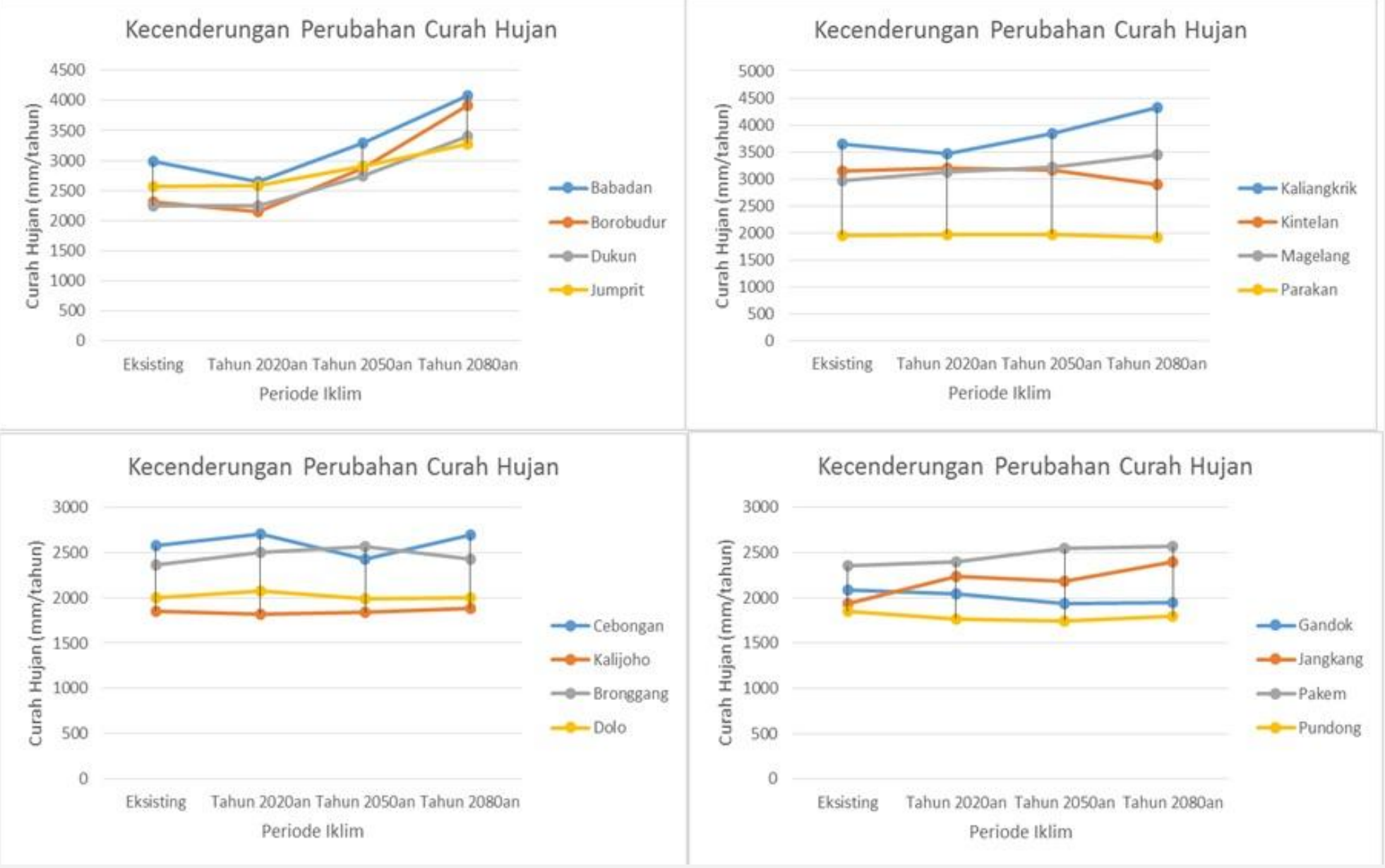

Sumber: Cahyadi dkk. (2016) 


\section{Peranan Hidrologi dan Speleologi}

\subsection{Karakterisasi Kawasan Karst III (Karakterisasi Hidrologi)}
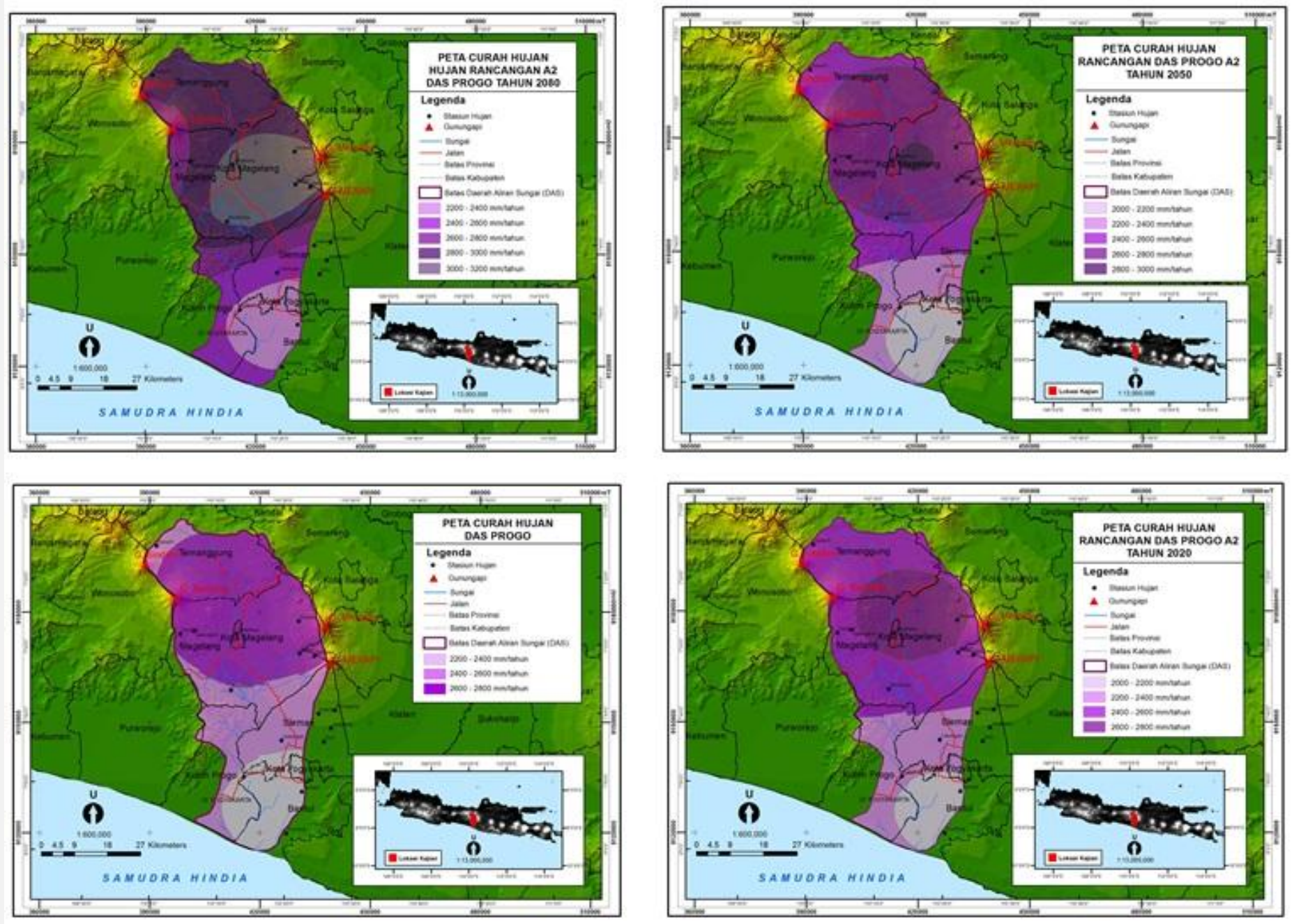

Sumber: Cahyadi dkk. (2016) 


\section{Peranan Hidrologi dan Speleologi}

\subsection{Karakterisasi Kawasan Karst III (Karakterisasi Hidrologi)}

Klasifikasi Derajat Karstifikasi Akuifer Karst (Dk)

\begin{tabular}{c|c} 
Dk & \multicolumn{2}{|c}{ Klasifikasi Akuifer } \\
\hline$<10$ & Akuifer yang sistemnya didominasi aliran diffue (Darcian Aquifer) \\
\hline
\end{tabular}

10-20 Akuifer yang telah terkarstifikasi sebagian (Partially Karstified Aquifer)

20-60 Akuifer yang telah terkarstifikasi (Karstified Akuifer)

>60 Akuifer yang telah terkarstifikasi lanjut (Highly Karstified Aquifer)

Sumber: Rashed (2012) 


\section{Peranan Hidrologi dan Speleologi}

\subsection{Karakterisasi Kawasan Karst III (Karakterisasi Hidrologi)}

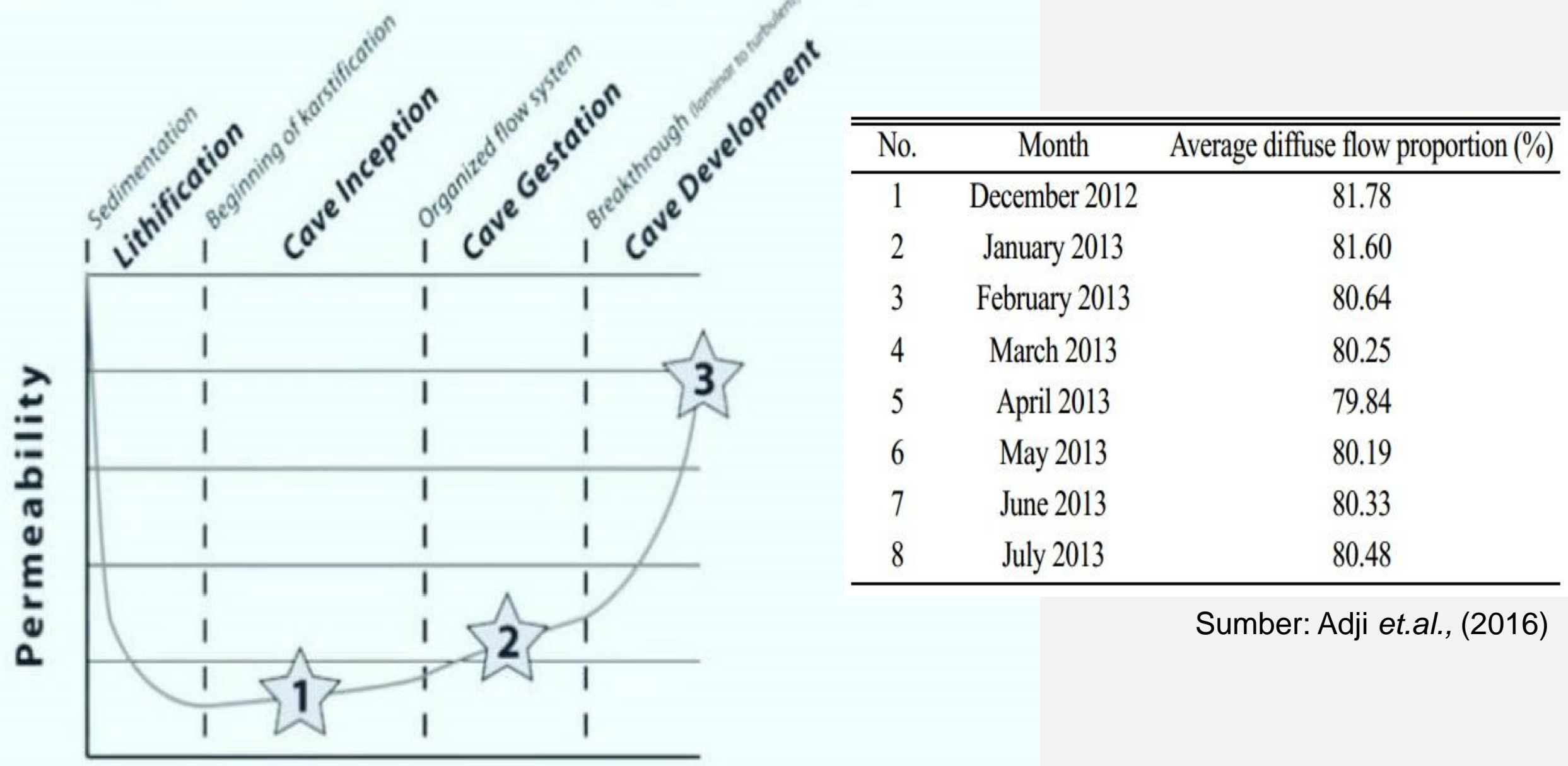

Time 


\section{Peranan Hidrologi dan Speleologi}

\subsection{Karakterisasi Kawasan Karst IV (Karakterisasi Hidrogeokimia)}
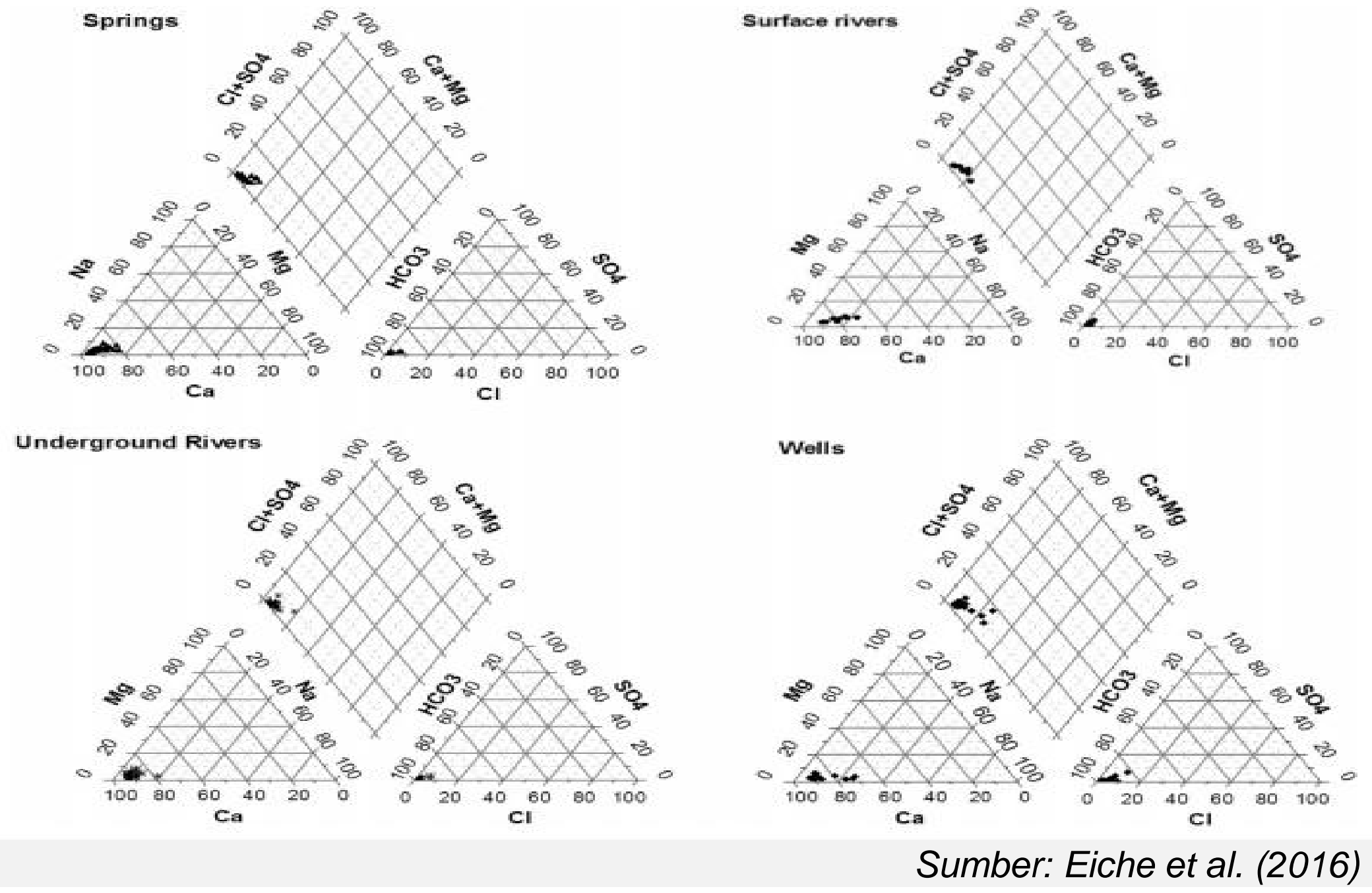


\section{Peranan Hidrologi dan Speleologi}

5.4. Karakterisasi Kawasan Karst IV (Karakterisasi Hidrogeokimia)

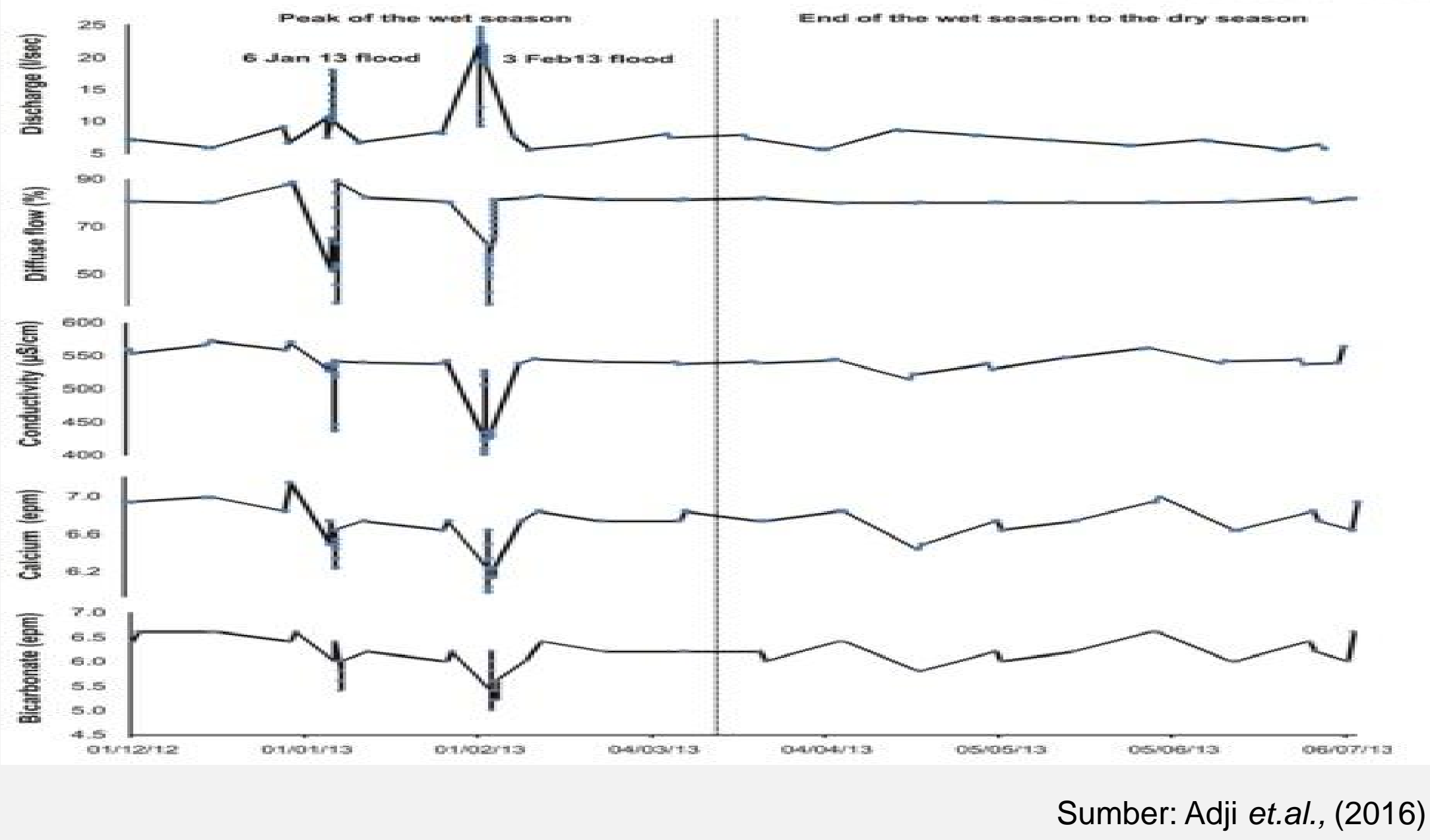




\section{Peranan Hidrologi dan Speleologi}

\subsection{Karakterisasi Kawasan Karst V (Karakterisasi Gua)}

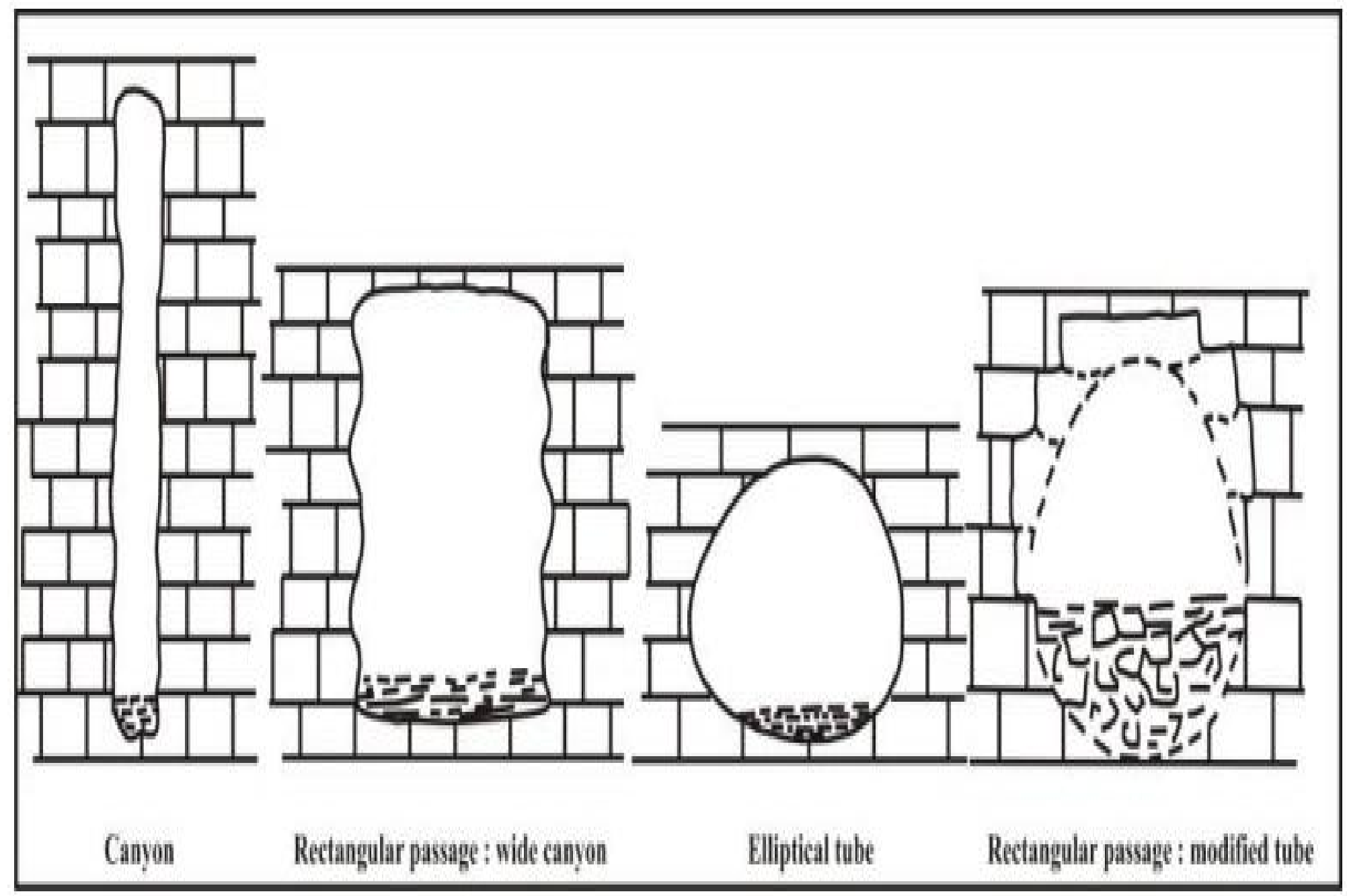

Bentuk lorong gua yang dikontrol aktivitas hidraulik

Sumber: White (1988) 


\section{Peranan Hidrologi dan Speleologi}

5.5. Karakterisasi Kawasan Karst V (Karakterisasi Gua)

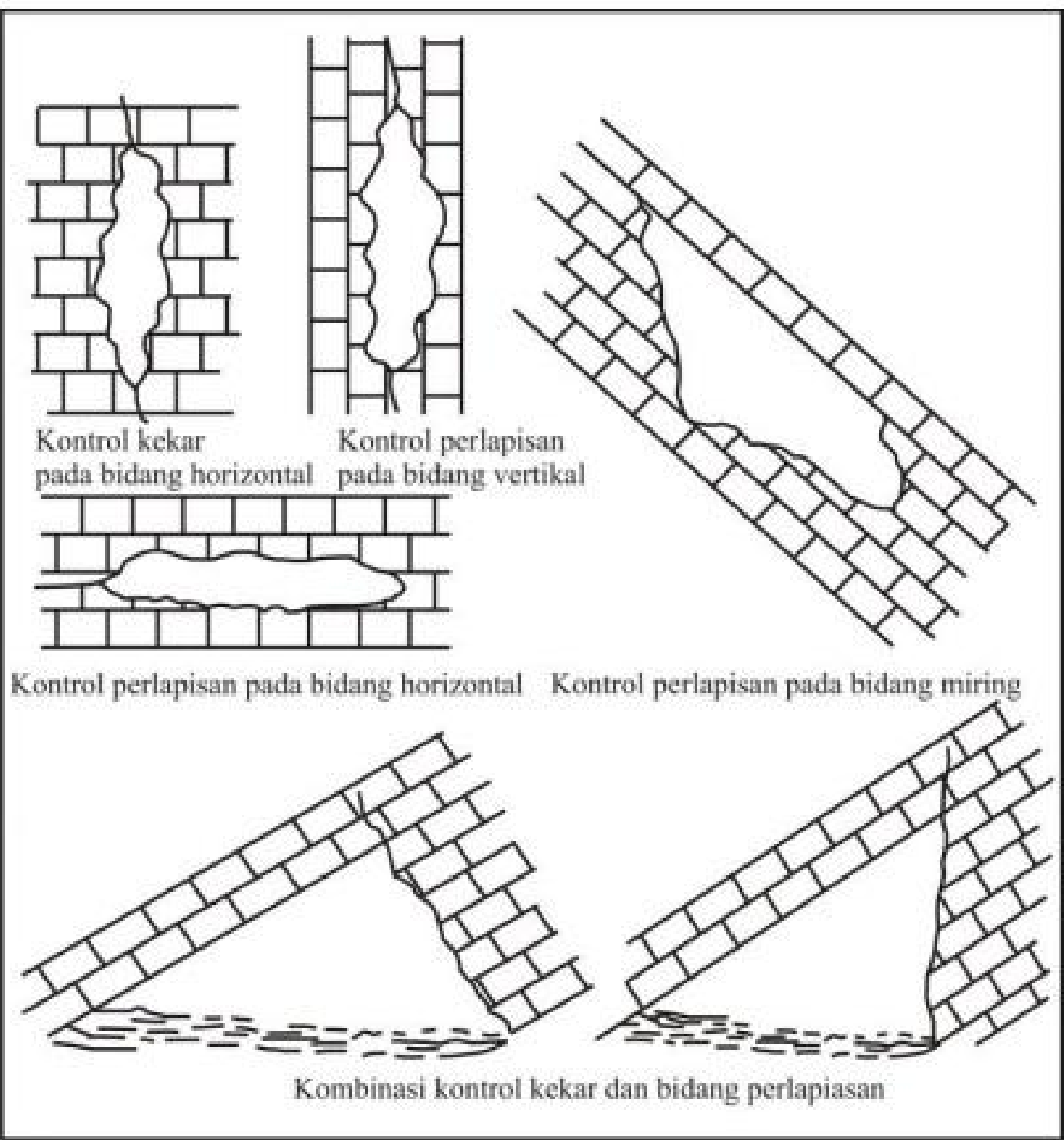

Bentuk lorong gua yang dikontrol Struktur 


\section{Peranan Hidrologi dan Speleologi}

\subsection{Karakterisasi Kawasan Karst V (Karakterisasi Gua)}

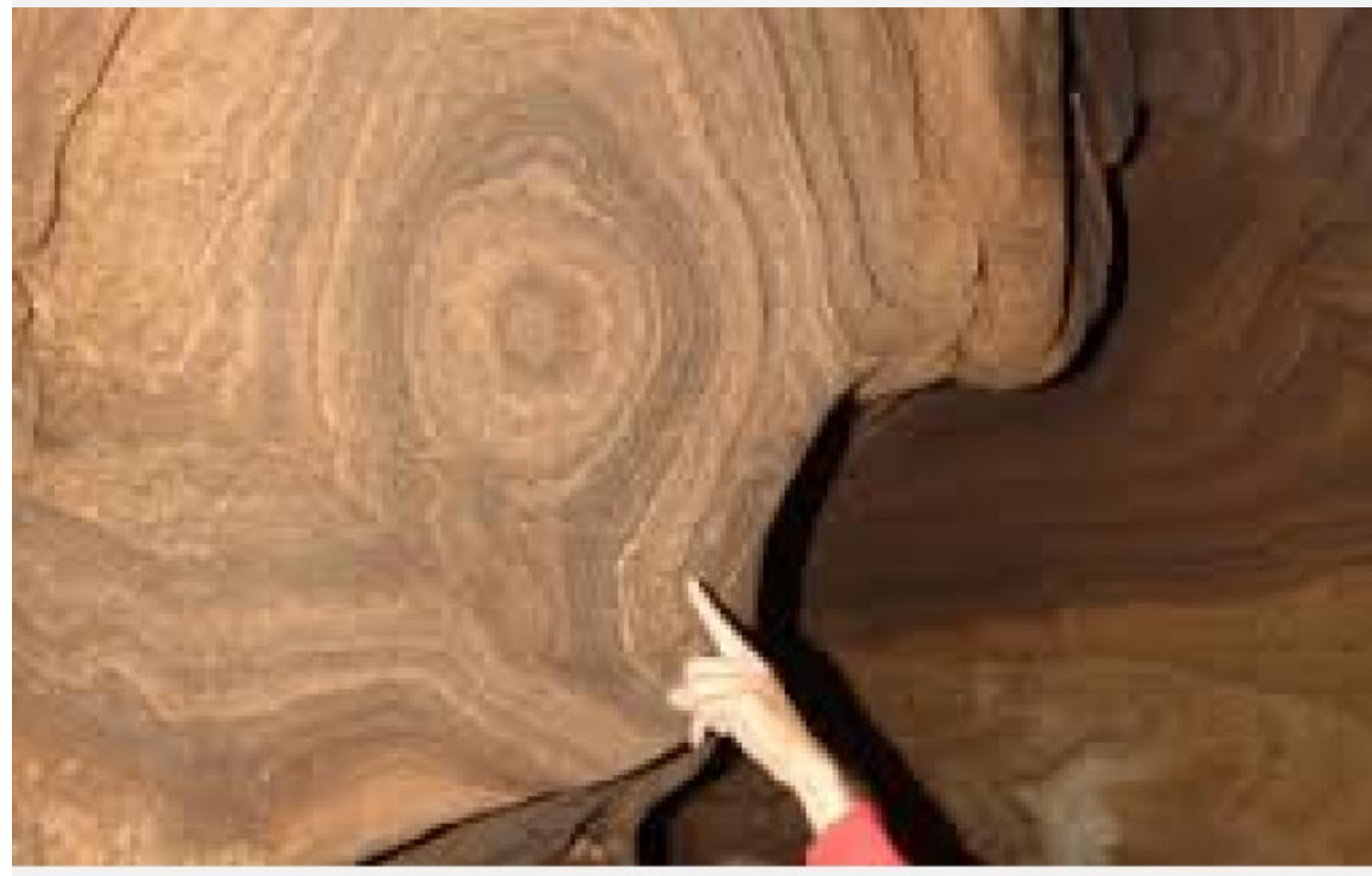

Jejak gempabumi di dalam gua

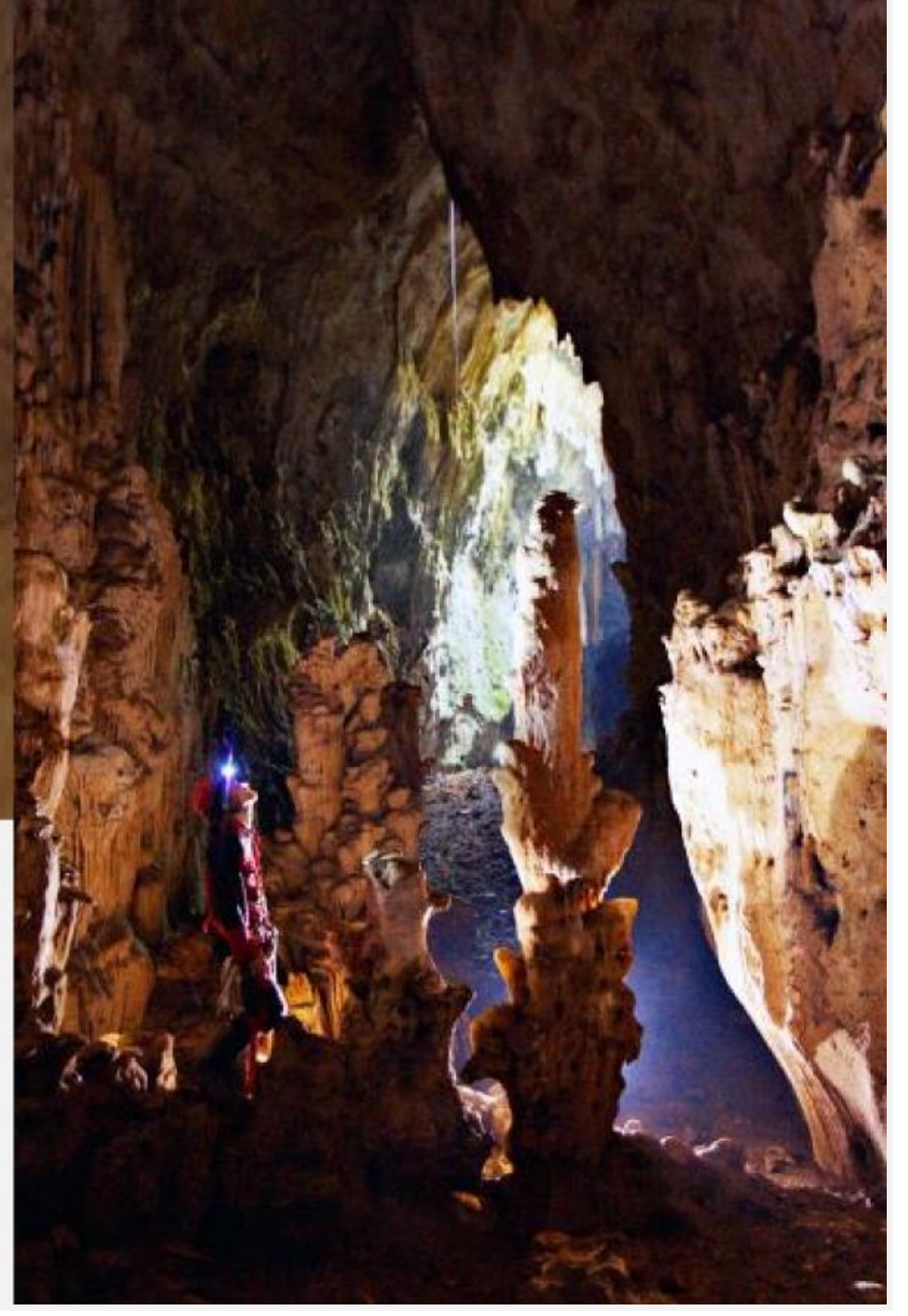




\section{Peranan Hidrologi dan Speleologi}

\subsection{Karakterisasi Kawasan Karst V (Karakterisasi Gua)}

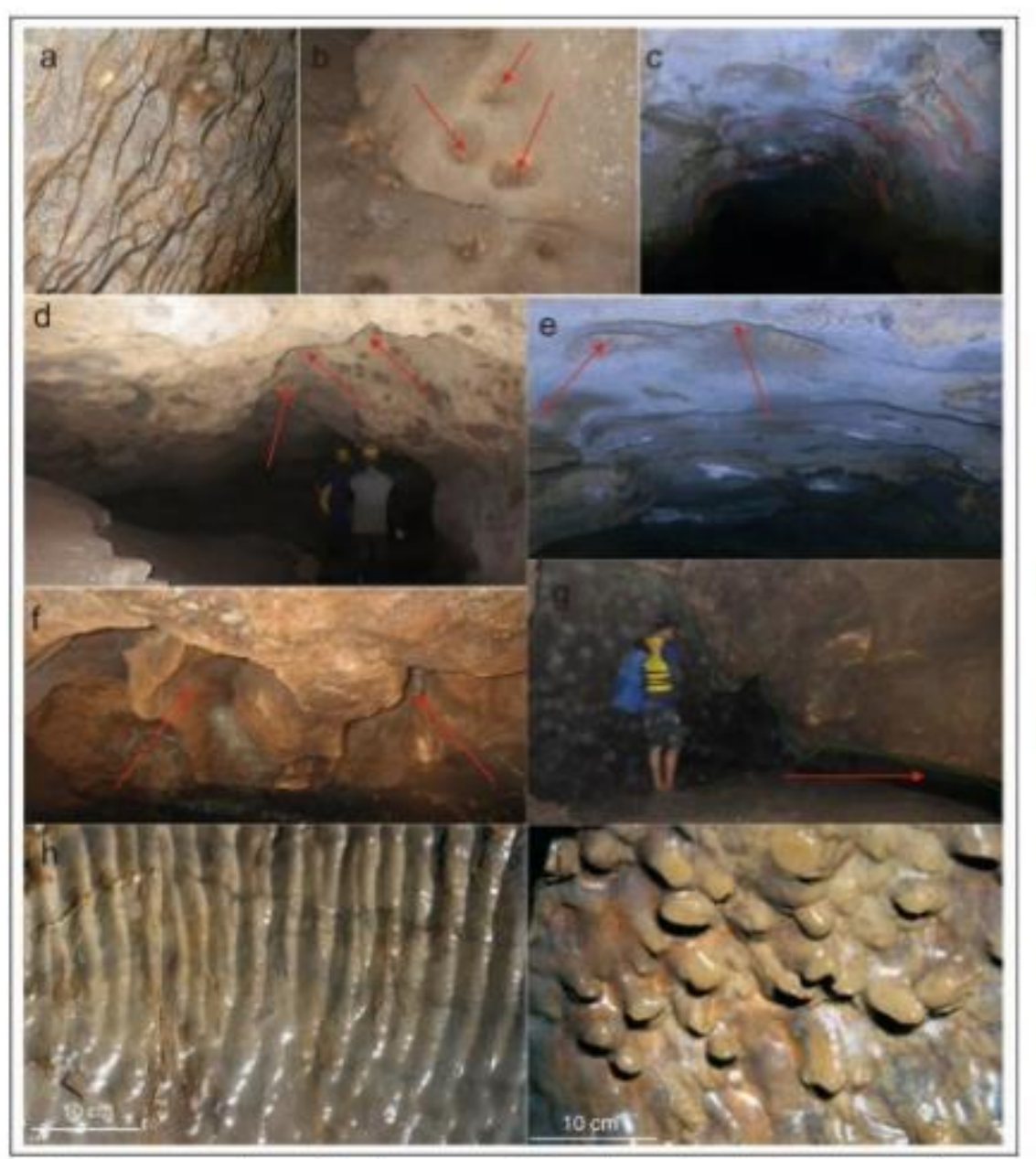

Gambar 6.6. Kenampakan Speleogen a) Pendant b) Potholes c) Scallops d) Solutions Pocket e) Cupola f) Meandering g) Solutions Notch h dan i berupa Flutes dan Cups/pits di Ambil dari Slabe dan Prelovsek, 2013. 


\section{Peranan Hidrologi dan Speleologi}

\subsection{Karakterisasi Kawasan Karst V (Karakterisasi Gua)}
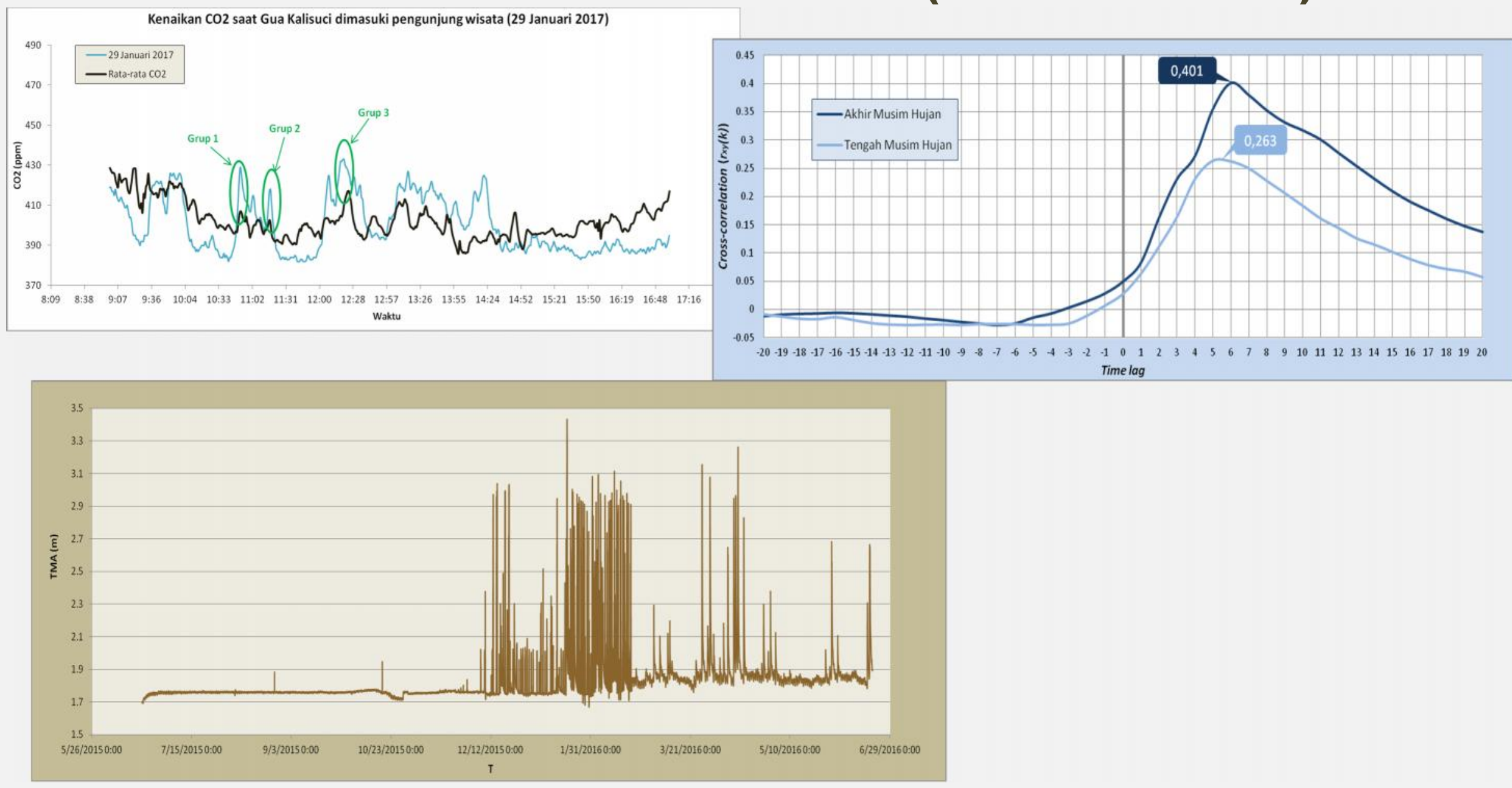

Sumber: Prabawa (2017) 


\section{Peranan Hidrologi dan Speleologi}

\section{Apakah stalagtit yang meneteskan air berarti gua masih hidup?}

Tidak. Hal ini karena proses pelarutan dan pengendapan akan sangat tergantung pada agresivitas dari aliran air pada stalagtit. Dalam kondisi jenuh, air akan bersifat tidak agresif dan lebih banyak mengendapkan, sedangkan pada kondisi agresif air akan cenderung melarutkan batuan. Kondisi demikian dapat bersifat permanen ataupun berubah musiman. 


\section{Peranan Hidrologi dan Speleologi}

5.6. Karakterisasi Kawasan Karst VI (Karakterisasi Geomorfologi)

- Karakteristik geomorfologi adalah karakteristik permukaan dari kawasan karst

* Bentukan-bentukan yang khas dan unik adalah potensi yang sangat besar dalam penentuan lokasi geosite

- Bentukan yang memerlukan perlindungan karena keunikannya misalnya sinking stream, logva, gua, menara karst, pinnacle karst, natural bridge dan lain-lain 


\section{Peranan Hidrologi dan Speleologi}

\subsection{Karakterisasi Kawasan Karst VI (Karakterisasi Geomorfologi)}

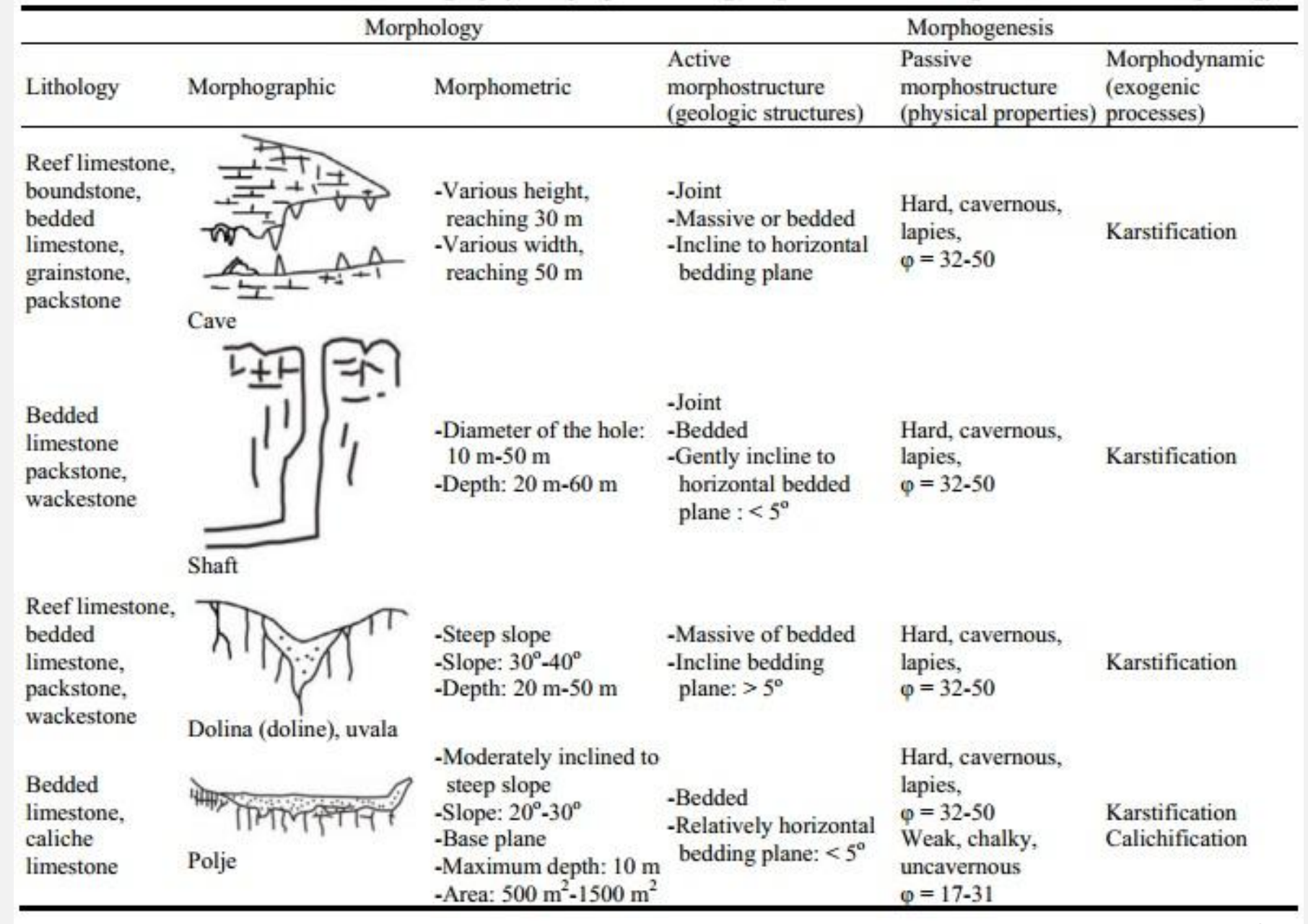

Kusumayudha dkk (2015) 


\section{Peranan Hidrologi dan Speleologi}

5.7. Karakterisasi Kawasan Karst VII (Analisis Isotop)

* Analisis Isotop dapat digunakan untuk analisis iklim masa lampau, penggunaan lahan masa lampau, dan rekonstruksi lingkungan masa lampau, sehingga dapat pula digunakan untuk rekonstruksi perkembangan gua dan atau kawasan karst di mana gua tersebut berada

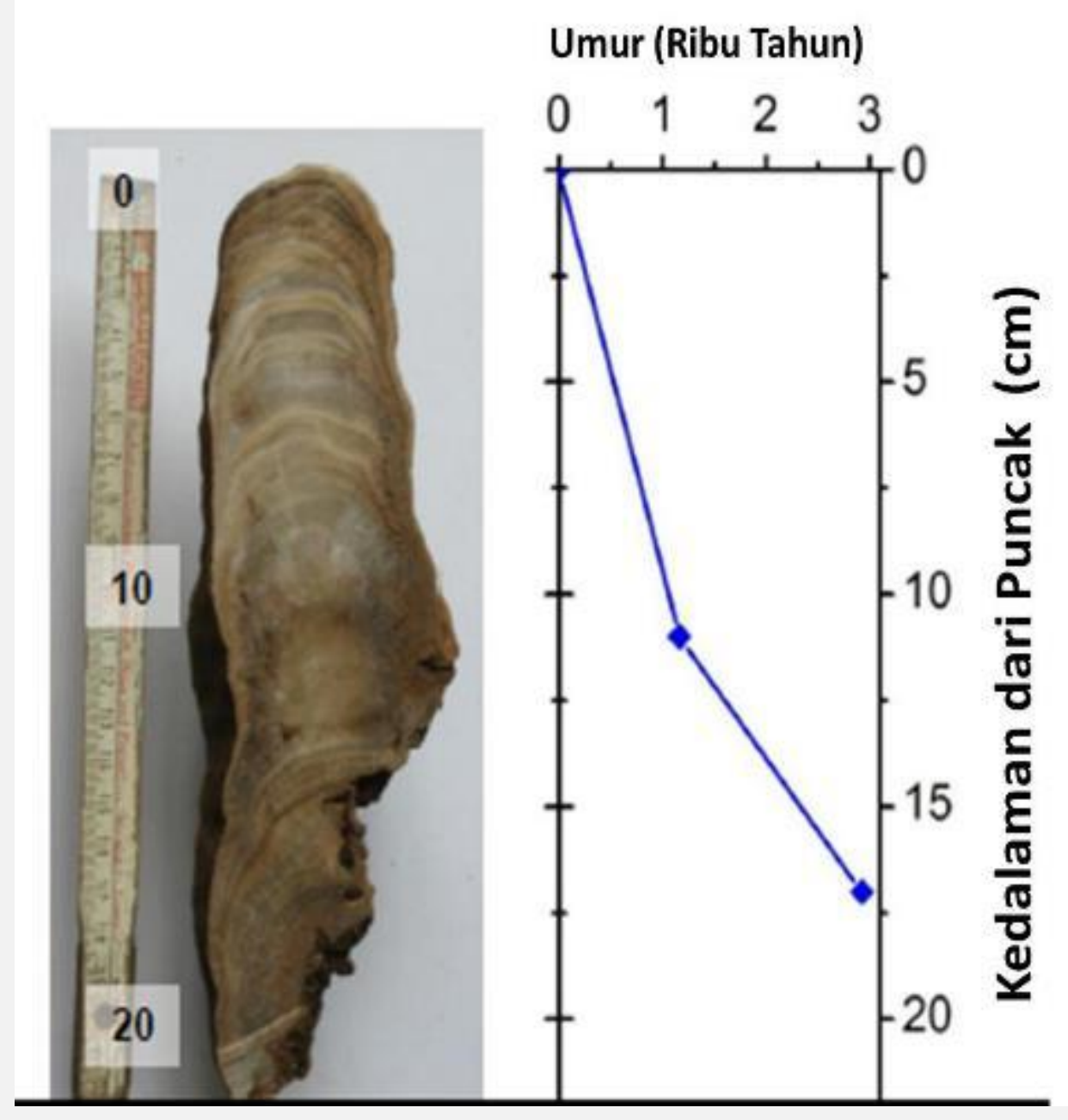




\section{Peranan Hidrologi dan Speleologi}

5.8. Karakterisasi Kawasan Karst VIII (Analisis Serapan dan Simpanan Karbon)

* Analisis simpanan karbon di dalam kawasan karst sangat penting

* Perusakan kawasan ini berarti pelepasan karbon ke sistem yang lain

* Simpanan karbon kawasan karst berada dalam batuan, tanah dan vegetasi

- Penyerapan karbondioksida atmosfer juga menjadi sangat penting

* Proses penyerapan terjadi dalam proses pelarutan, di mana pelarutan 1.000 kg gamping akan diikuti dengan penyerapan karbondioksida atmosfer sebanyak $200 \mathrm{~kg}$ 


\section{Peranan Hidrologi dan Speleologi}

5.9. Karakterisasi Kawasan Karst IX (Karakterisasi Kerentanan Airtanah)

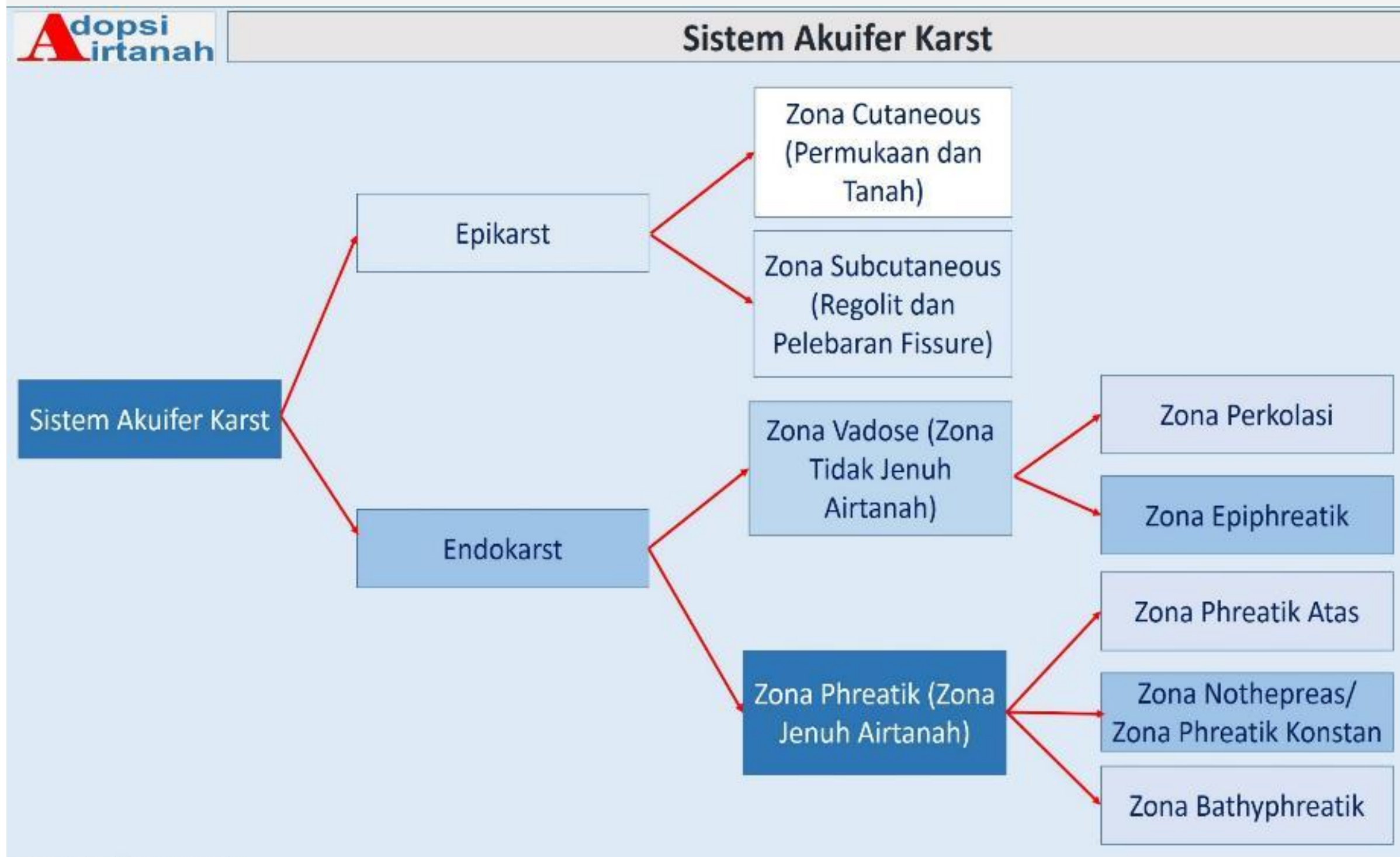




\section{Peranan Hidrologi dan Speleologi}

5.9. Karakterisasi Kawasan Karst IX (Karakterisasi

Kerentanan Airtanah)

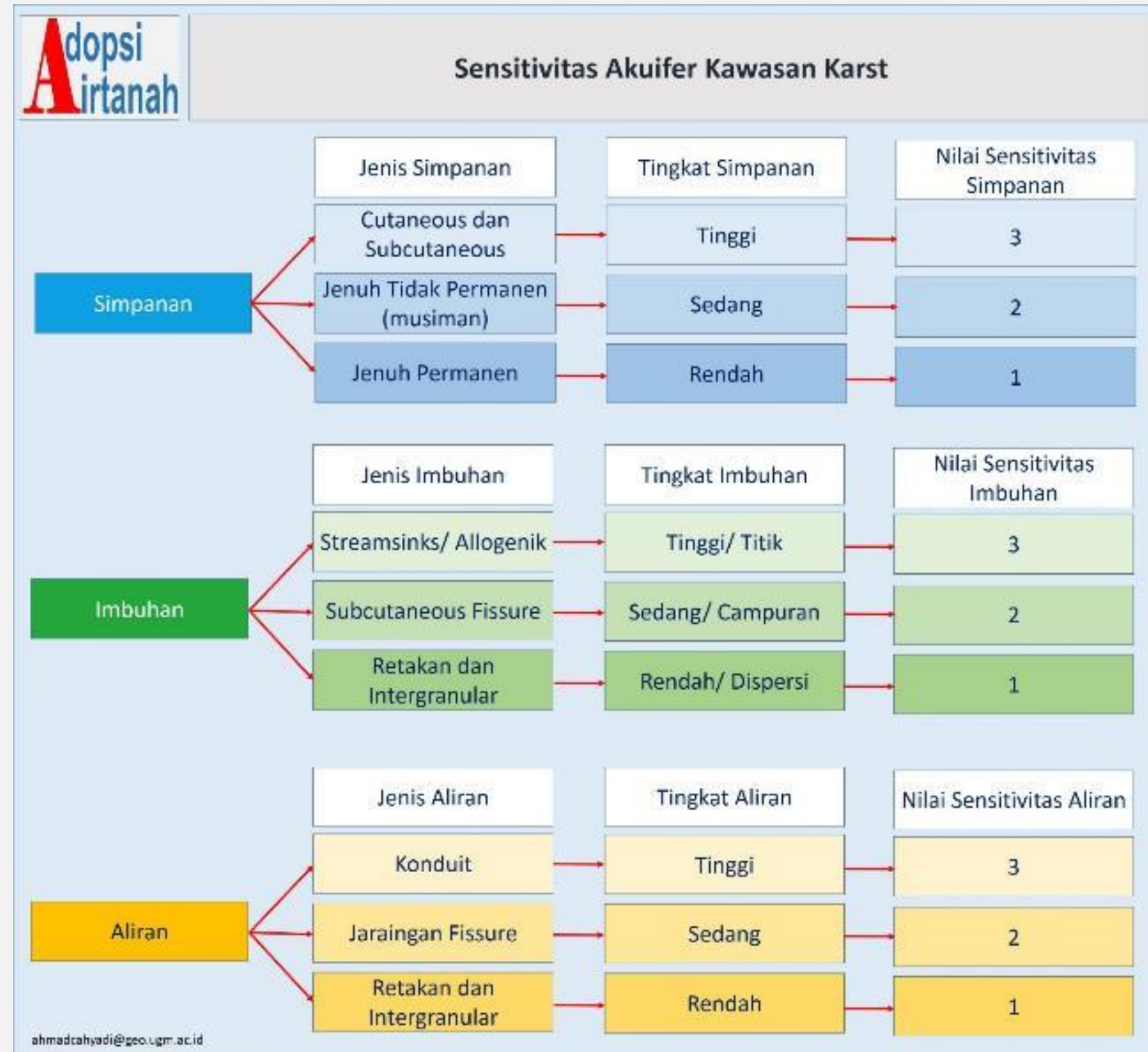




\section{Peranan Hidrologi dan Speleologi}

\subsection{Karakterisasi Kawasan Karst X (Karakterisasi Imbuhan Airtanah)}

\section{Empat Komponen Utama Imbuhan Akuifer Karst}

1. Allogenic Recharge: Yaitu aliran permukaan berupa sungai permukaan dari luar kawasan karst yang masuk ke dalam akuifer karst melalui ponor dan atau sinkhole;

2. Internal Runoff: yaitu aliran permukaan dan hujan yang jatuh pada suatu cekungan tertutup (doline) di kawasan karst dan kemudian masuk ke dalam sistem akuifer karst melalui ponor;

3. Diffuse Infiltration: yaitu air hujan yang jatuh ke dalam tanah kemudian terinfiltrasi secara perlahan melalui pori pori tanah yang disimpan dalam kurun waktu mingguan sampai bulanan pada zona epikarst sebelum masuk ke sistem akuifer karst melalui rekahan batuan dan atau matriks batuan (ruang antar butir batuan);

4. Imbuhan akuifer dari akuifer bertengger atau menggantung (perched aquufer), yaitu imbuhan yang berasal dari akuifer lokal yang secara geologi terbentuk di atas akuifer karst dan kemudian memasok air ke akuifer karst melalui ruang antar butir atau rekahan yang terbentuk 


\section{5.}

\section{Peranan Hidrologi dan Speleologi}

5.10. Karakterisasi Kawasan Karst X (Karakterisasi Imbuhan Airtanah)
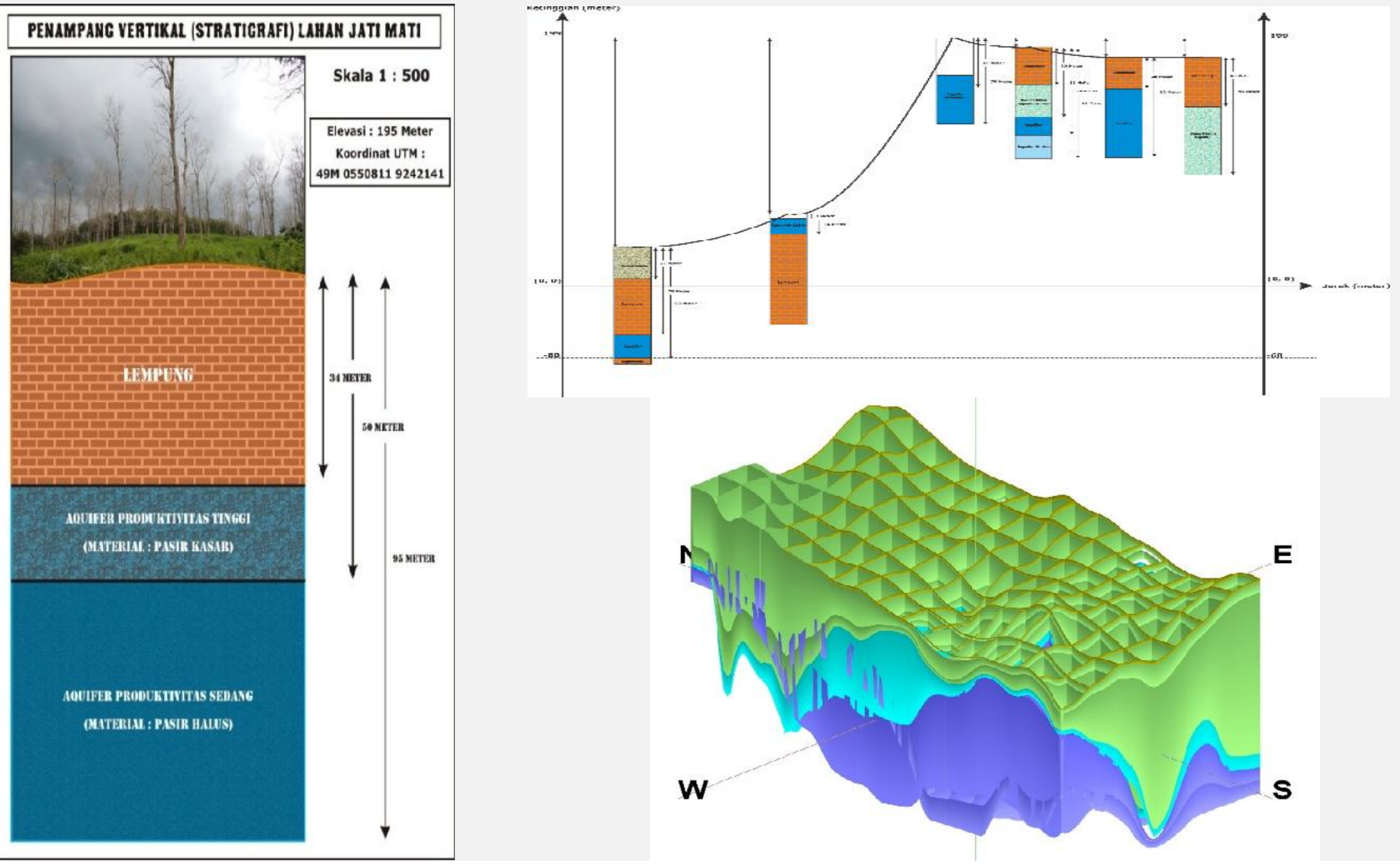


\section{Peranan Hidrologi dan Speleologi}

5.10. Karakterisasi Kawasan Karst X (Karakterisasi Imbuhan Airtanah)
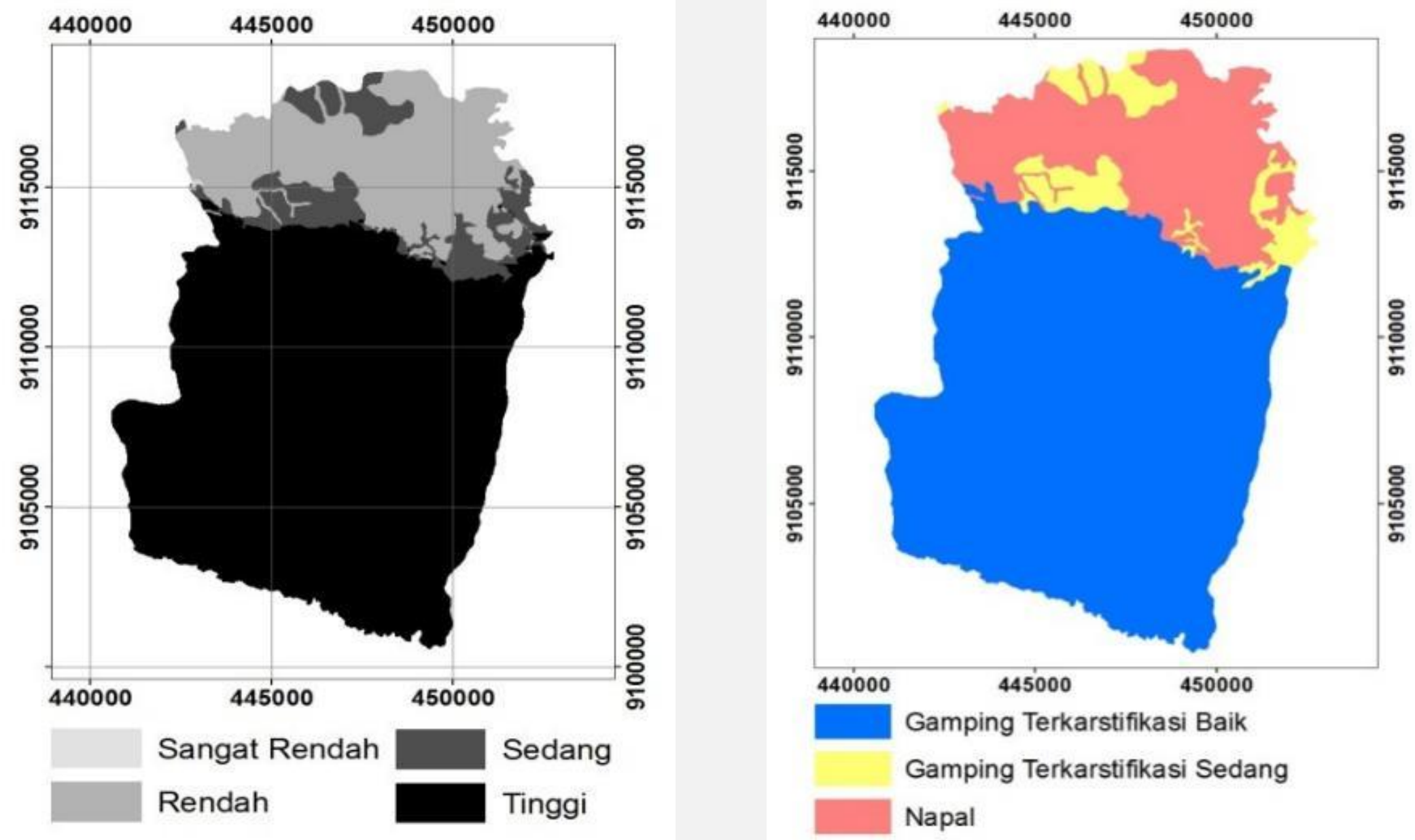

Sumber: Cahyadi dan Hartoyo (2011) 


\section{Pengelolaan Kawasan Karst}

6.1. Pengelolaan Kawasan Karst

- Beberapa hal yang harus diperhatikan dalam pengelolaan kawasan karst adalah:

1. Perlunya disusun ulang pengertian kawasan karst di Indonesia, sekaligus cara penialaiannya;

2. Karakterisasi kawasan karst membutuhkan data yang detail, sehingga mendesak untuk dilakukan penyediaan data dasar untuk mendukungnya;

3. Karakterisasi kawasan karst membutuhkan kajian multidisiplin, sehingga perlu melibatkan banyak instansi dan lembaga;

4. Karakterisasi kawasan karst membutuhkan kajian yang lama (misalnya satu tahun untuk hidrologi), sehingga tidak dapat dilakukan hanya dalam waktu yang singkat atau insidentil;

5. Keterlibatan banyak pihak menjadi sangat penting karena mendesaknya penyediaan terkait dengan karakterisasi kawasan karst di Indonesia 


\section{DAFTAR PUSTAKA}

Adji, T.N.A. dan Cahyadi, A. 2016. Pentingnya Monitoring Parameter-Parameter Hidrograf Dalam Pengelolaan Airtanah di Daerah Karst. Seminar Ekolhidrolika. Yogyakarta: APCE-UNESCO, LIPI dan UGM.

Adji, T.N.; Haryono, E.; Fatchurohman, H. and Oktama, R. 2016. Diffuse Flow Characteristics and Their Relation to Hydrochemistry Conditions in The Petoyan Spring, Gunungsewu Karst, Java, Indonesia. Geosciences Journal, 20(3): 381-390.

Agniy, R.F. dan Cahyadi, A. 2015. Analisis Evolusi Hidrogeokimia Airtanah di Sebagian Mataair Karst Kabupaten Rembang Bagian Selatan. Prosiding Seminar Nasional Innovation in Environmental Management. Semarang: Universitas Diponegoro.

Agniy, R.F. 2016. Hidrogeologi Sistem Gua Pindul, Kabupaten Gunungkidul. Skripsi. Yogyakarta: Fakultas Geografi Universitas Gadjah Mada.

Agniy, R.F.; Haryono, E. dan Cahyadi, A. 2016. Karakteristik dan Pemanfaatan Mataair di Daerah Tangkapan Sistem Goa Pindul, Karangmojo, Gunungkidul. Dalam Suprayogi, S.; Purnama, S.; Cahyadi, A. dan Fatchurohman, H. 2016. Hidrologi dan Kepariwisataan Kawasan Karst Goa Pindul, Kabupaten Gunungkidul. Yogyakarta: Badan Penerbit Fakultas Geografi UGM.

Agniy, R.F.; Cahyadi, A. dan Nurkholis, A. 2017. Analisis Karakteristik Akuifer Karst dengan Uji Perunutan dan Pemetaan Gua. Pertemuan IImiah Tahunan Perhimpunan Ahli Airtanah Indonesia ke-2. Yogyakarta: Universitas Gadjah Mada.Goldscheider, N., Meiman, J., Pronk, M dan Smart, C. 2008. Tracer Tests in Karst Hydrogeology and Speleology. International Journal of Speleology, 37 (1): 27-40.

Bahtiar, I.Y. dan Cahyadi, A. 2014. Analisis Karakteristik Hidrologi Aliran Sungai Bawah Tanah di Kawasan Karst untuk Mendukung Pengembangan Geowisata. dalam Cahyadi, A.; Prabawa, B.A.; Tivianton, T.A. dan Nugraha, H. 2014. Ekologi Lingkungan Kawasan Karst Indonesia: Mejaga Asa Kelestarian Kawasan Karst Indonesia, Edisi 2. Yogyakarta: Deepublish. Hal: 13-22.

Cahyadi, A. 2010. Pengelolaan Kawasan Karst dan Peranannya dalam Siklus Karbon di Indonesia. Prosiding Seminar Nasional Perubahan Iklim di Indonesia. Yogyakarta: Sekolah Pascasarjana Universitas Gadjah Mada.

Cahyadi, A. dan Hartoyo, F.A. 2011.Pemanfatan Sistem Informasi Geografis (Sig) Untuk Pemetaan Imbuhan Airtanah dan Kerentanan Airtanah di Kawasan Karst (Studi Kasus di Kecamatan Paliyan Dan Kecamatan Saptosari, Kabupaten Gunungkidul). Prosiding Seminar Nasional Aplikasi Teknologi Informasi. Yogyakarta: Universitas Islam Indonesia.

Cahyadi, A. dan Priadmodjo, A. 2012. Pengaruh Penambangan Gamping terhadap Fungsi Penyerapan Karbondioksida (CO2) Atmosfer di Kawasan Karst Kecamatan Ponjong, Kabupaten Gunungkidul. Makalah dalam Seminar Nasional Geospatial Day. Surakarta: Universitas Sebelas Maret.

Cahyadi, A.; Nucifera, F.; Marfai, M.A. dan Rahmadana, A.D.W. 2012. Perencanaan Penggunaan Lahan di Kawasan Karst Berbasis Analisis kemampuan Lahan dan Pemetaan Kawasan Lindung Sumberdaya Air (Studi Kasus di Kecamatan Ponjong, Kabupaten Gunungkidul, D.I. Yogyakarta). Prosiding Seminar Nasional Science, Engineering and Technology, 23-24 Februari 2012. Program Magister dan Doktor Fakultas Teknik Universitas Brawijaya, Malang.

Cahyadi, A. 2013. Tingkat Pengetahuan Masyarakat Terhadap Keberadaan dan Penyebab Kerusakan Sumberdaya Air Sungai Bawah Tanah di Kawasan Karst Gunungsewu. Geomedia, 11(2): 253-260.

Cahyadi, A.; Prabawa, B.A. dan Putranto, S.A. 2013a. Pengelolaan Kawasan Karst Gunungsewu Sebagai Upaya Melestarikan Fungsi Penyerapan Karbondioksida. Marfai, M.A. dan Widyastuti, M. 2013. Pengelolaan Lingkungan Zamrud Khatulistiwa. Yogyakarta: Buku Pintal.

Cahyadi, A., Pratiwi, E.S. dan Fatchurohman, H. 2013b. Metode-metode Identifikasi Karakteristik Daerah Tangkapan Air Sungai Bawah Tanah dan Mataair Kawasan Karst: Suatu Tinjauan. dalam Marfai, M.A. dan Widyastuti, M. 2013. Pengelolaan Lingkungan Zamrud Khatulistiwa. Yogyakarta: Pintal.

Cahyadi, A.; Ayuningtyas, E.A. dan Prabawa, B.A. 2013c. Urgensi Pengelolaan Sanitasi dalam Upaya Konservasi Sumberdaya Air di Kawasan Karst Gunungsewu Kabupaten Gunungkidul. Indonesian Journal of Conservation, 2(1): 23-32.

Cahyadi, A. 2014a. Keunikan Hidrologi Kawasan Karst: Suatu Tinjauan. dalam Cahyadi, A.; Prabawa, B.A.; Tivianton, T.A. dan Nugraha, H. 2014. Ekologi Lingkungan Kawasan Karst Indonesia: Mejaga Asa Kelestarian Kawasan Karst Indonesia, Edisi 2. Yogyakarta: Deepublish. Hal: 1 - 13. 
Cahyadi, A. 2014b. Sumberdaya Lahan Kawasan Karst Gunungsewu. dalam Cahyadi, A.; Prabawa, B.A.; Tivianton, T.A. dan Nugraha, H. 2014. Ekologi Lingkungan Kawasan Karst Indonesia: Mejaga Asa Kelestarian Kawasan Karst Indonesia, Edisi 2. Yogyakarta: Deepublish. Hal: $102-113$.

Cahyadi, A. 2016a. Isu-isu Riset Ilmu Kebumian Terkini di Kawasan Karst. Dalam Suprayogi, S.; Purnama, S.; Cahyadi, A. dan Fatchurohman, H. 2016. Hidrologi dan Kepariwisataan Kawasan Karst Goa Pindul, Kabupaten Gunungkidul. Yogyakarta: Badan Penerbit Fakultas Geografi UGM.

Cahyadi, A. 2016b. Peran Telaga dalam Pemenuhan Kebutuhan Air Kawasan Karst Gunungsewu Pasca Pembangunan Jaringan Air Bersih. Geomedia, 14(2): 23-33.

Cahyadi, A. dan Agniy, R.F. 2016. Analisis Breakthrough Curve untuk Karakteristerisasi Pelorongan di Sistem Sungai Bawah Tanah Pindul Kabupaten Gunungkidul. Prosiding Pekan Ilmiah Tahunan Perhimpunan Ahli Airtanah Indonesia ke 1. Bandung: ITB Press.

Cahyadi, A.; Riyanto, I.A. dan Nurrohmah, H. 2016. Estimasi Dampak Perubahan Iklim Terhdap Imbuhan Airtanah di Daerah Aliran Sungai Progo. Laporan Penelitian.Yogyakarta: Fakultas Geografi Universitas Gadjah Mada.

Eiche, E.; Hochschild, M.; Haryono, E. and Neumann, T. 2016. Characterization of Recharge and Low Behaviour of different water sources in Gunung Kidul and its impact on Water Quality Based on Hydrochemical and Physico-Chemical Monitoring. Applied Water Science, 10.1007/s13201-0160426-z.

Fatchurohman, H.; Cahyadi, A. dan Suprayogi, S. 2016. Hydrograph Analysis for Sustainable Karst Aquifer Protection and Management. Geomedia 14(1), 43-53.

Gellieson, D. 1996. Caves: Processes, Development, and Management. British: Blacwell Publishers.

Haryono, E. 2009. Model Perkembangan Karst Berdasarkan Morfometri Jaringan Lembah di Karang Bolong, Gunung Sewu, Blambangan dan Rengel. Disertasi. Yogyakarta: Fakultas Geografi Universitas Gadjah Mada.

Haryono, E. 2011. Introduction to Gunungsewu Karst. Field Guide of Asian Trans-Disciplinary Karst Conference. Yogyakarta: Karst Research Group, Faculty of Geography, Universitas Gadjah Mada.

Haryono, E. dan Labib, M.A. 2016. Identifikasi Morfologi Lorong Gua di Kawasan Karst. Dalam Haryono, E. 2016. Pedoman Praktis Survei Terintegrasi Kawasan Karst. Yogyakarta: Badan Penerbit Fakultas Geografi Universitas Gadjah Mada.

Haryono, E.; Bariadi, D.H. dan Cahyadi, A. 2017. idrogeologi Kawasan Karst Gunungsewu: Panduan Lapangan Fieldtrip PAAI 2017. Yogyakarta: Perhimpunan Ahli Airtanah Indonesia, Groundwater Working Group UGM dan Kelompok Studi Karst Fakultas Geografi Universitas Gadjah Mada.

Hidayat, A.; Suprayogi, S. dan Cahyadi, A. 2016. Analisis Kesesuaian Kualitas air untuk Irigasi pada Beberapa Mataair di Kawasan Karst Sistem Goa Pindul. Dalam Suprayogi, S.; Purnama, S.; Cahyadi, A. dan Fatchurohman, H. 2016. Hidrologi dan Kepariwisataan Kawasan Karst Goa Pindul, Kabupaten Gunungkidul. Yogyakarta: Badan Penerbit Fakultas Geografi UGM.

Jurnawan, N.Y.; Putnama, S. dan Cahyadi, A. 2016. Analisis Potensi Sungai Bawah Tanah Ngancar untuk Pemanfaatan Sebagai Sumber Air Minum. Dalam Suprayogi, S.; Purnama, S.; Cahyadi, A. dan Fatchurohman, H. 2016. Hidrologi dan Kepariwisataan Kawasan Karst Goa Pindul, Kabupaten Gunungkidul. Yogyakarta: Badan Penerbit Fakultas Geografi UGM.

Klimchouk, A. 2015. The Karst Paradigm: Changes, Trends and Perspectives. Acta Cartalogica, 44(3): 289313.

Kusumayudha, S.B.; Setiawan, J.; Ciptahening, A.N. and Septianta, P.D.. 2015. Geomorphologic Model of Gunungsewu Karst, Gunung Kidul Regency, Yogyakarta Special Territory, Indonesia: The Role of Lithologic Variation and Geologic Structure. Journal of Geological Resource and Engineering, 1: 17.

Lestariningsih, S.P.; Cahyadi, A.; Rahmat, P.N.dan Zein, A.G.I. 2013. Tekanan Penduduk Terhadap Lahan di Kawasan Karst (Studi Kasus di Desa Songbanyu, Kecamatan Girisubo dan Desa Jeruk Wudel Kecamatan Rongkop, Gunungkidul). dalam Sudarmadji; E. Haryono; Adji, T.N.; Widyastuti, M.; Harini, R.; Nurjani, E.; Cahyadi, A. dan Nugraha, H. (editor). Ekologi Lingkungan Kawasan Karst Indonesia: Menjaga Asa Kelestarian Kawasan Karst Indonesia. Deepublish. Yogyakarta.

Malik, P. and Vojtkova, S., 2012, Use of recession-curve analysis for estimation of karstification degree and its application in assessing overflow/underflow conditions in closely spaced karstic springs, Environmental Earth Sciences Journal, 65(8): 2245-2257.

Marfai, M.A.; Sekaranom, A.B. and Cahyadi, A. 2015. Profiles of marine notches in the Baron coastal area-Indonesia. Arabian Journal of Geosciences, 8(1): 307-314. 
Nurkholis, A.; Cahyadi, A. dan Purnama, S. 2016. Evolusi Hidrogeokimia pada Mataair di Sistem Goa Pindul, Karangmojo, Kebupaten Gunungkidul. Dalam Suprayogi, S.; Purnama, S.; Cahyadi, A. dan Fatchurohman, H. 2016. Hidrologi dan Kepariwisataan Kawasan Karst Goa Pindul, Kabupaten Gunungkidul. Yogyakarta: Badan Penerbit Fakultas Geografi UGM.

Prabawa, B.A. 2017. Karakteristik Iklim Mikro Gua Kalisuci dan Banjir Sub DAS Jirak untuk Pengelolaan Wisata Berbasis Daya Dukung Gua. Tesis. Yogyakarta: Fakultas Geografi Universitas Gadjah Mada Yogyakarta.

Rashed, K.A., 2012, Assessing Degree of Karstification: A New Method Of Classifying Karst Aquifers, Sixteenth International Water Technology Conference, IWTC 16 2012, Istanbul, Turkey.

Riehl, C. dan Birk, S. 2010. Hydrogeological Characterisation and Modelling of Spring Chatchments in a Changing Environment. Austrian Journal of Earth Sciences, 103 (2), 106-117.

Rosaji, F.S.C. dan Cahyadi, A. 2012. Deteksi Telaga Potensial untuk Pemenuhan Kebutuhan Air Musim Kemarau di Kawasan Karst Menggunakan Data Penginderaan Jauh Multitemporal. Simposium Nasional Sains Informasi Geografis. Yogyakarta: PUSPICS UGM.

Sudarmadji; Marfai, M.A.; Cahyadi, A. dan Tivianton, T.A. 2015. Inisiasi Emergency Response System di Lokasi Wisata Minat Khusus Kalisuci, Gunungkidul. Jurnal Geografi dan Pendidikannya, 13(1):1425.

Suprayogi, S.; Purnama, S.; Agniy, R.F. dan cahyadi, A. 2016. Potensi Airtanah Statis di Daerah Tangkapan Air Goa Pindul Kabupaten Gunungkidul. Seminar Nasional Geografi Lingkungan I. Yogyakarta: Fakultas Geografi Universitas Gadjah Mada.

Suprayogi, S.; Agniy, R.F. dan Cahyadi, A. 2016. Urgensi Pengelolaan Kawasan Karst Goa Pindul, Kecamatan Karangmojo, Gunungkidul. Dalam Suprayogi, S.; Purnama, S.; Cahyadi, A. dan Fatchurohman, H. 2016. Hidrologi dan Kepariwisataan Kawasan Karst Goa Pindul, Kabupaten Gunungkidul. Yogyakarta: Badan Penerbit Fakultas Geografi UGM.

White, B, W.1988. Geomorphology and Hydrology of Karst Terrains. New York. Oxford University Press.

Widyastuti, M.; Cahyadi, A. dan Sasongko, M.H.D. 2016. Hidrologi dan Hidrogeologi Karst. Dalam Haryono, E. 2016. Pedoman Praktis Survei Terintegrasi Kawasan Karst. Yogyakarta: Badan Penerbit Fakultas Geografi Universitas Gadjah Mada. 


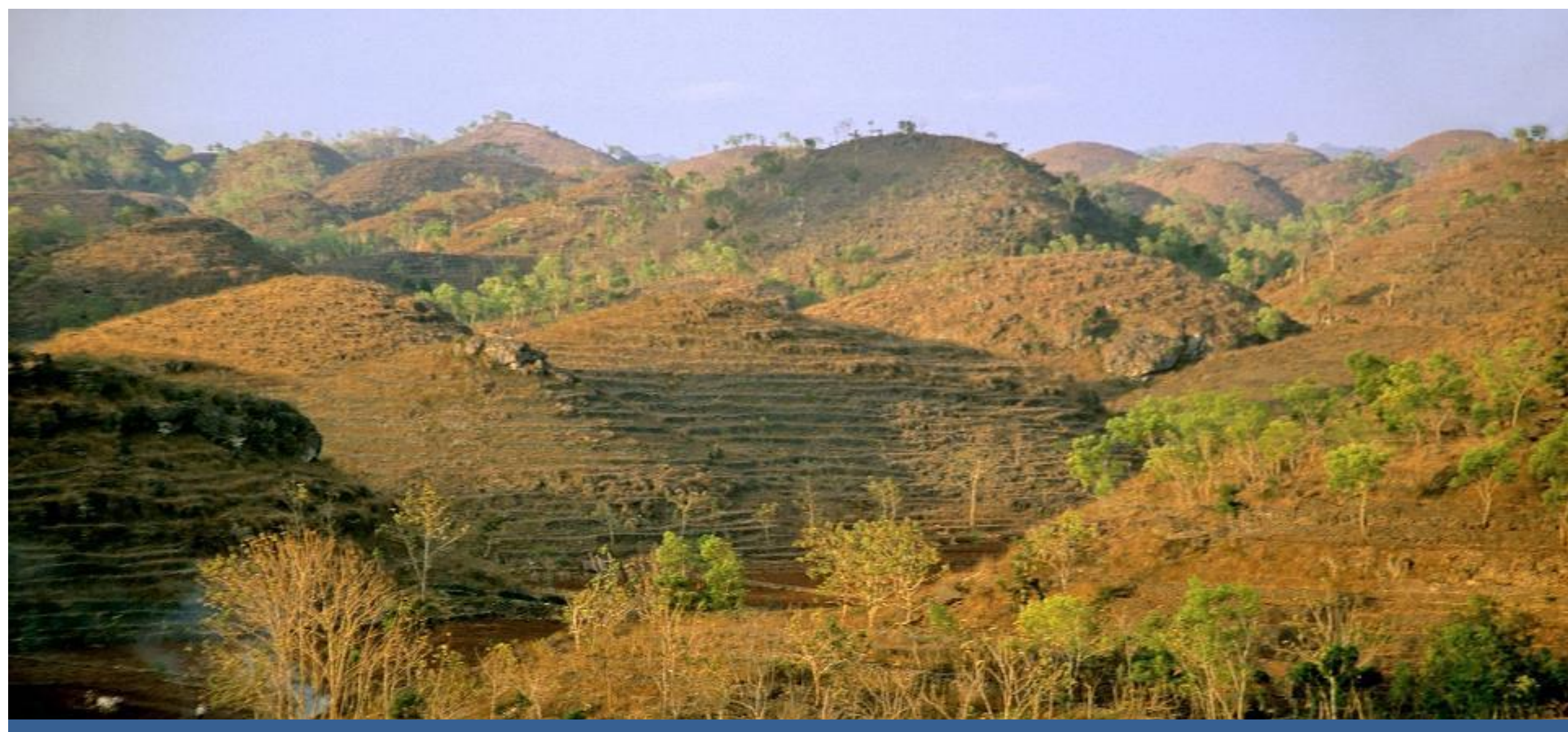

ahmadcahyadi@geo.ugm.ac.id

Terima Kasih 